Portland State University

PDXScholar

1972

\title{
The policy of containment and the Middle East, 1946-1958
}

Ahed George Samaan
Portland State University

Follow this and additional works at: https://pdxscholar.library.pdx.edu/open_access_etds

Part of the Diplomatic History Commons, Islamic World and Near East History Commons, and the United States History Commons

Let us know how access to this document benefits you.

\section{Recommended Citation}

Samaan, Ahed George, "The policy of containment and the Middle East, 1946-1958" (1972). Dissertations and Theses. Paper 967.

https://doi.org/10.15760/etd.967

This Thesis is brought to you for free and open access. It has been accepted for inclusion in Dissertations and Theses by an authorized administrator of PDXScholar. Please contact us if we can make this document more accessible: pdxscholar@pdx.edu. 
AN ABSTRACT OF THE THESIS OF Ahed George Samaan for the Master of Arts in History presented Ju1y 28, 1972.

Title: The Containment Policy and the Middle East: 1946-1958.

APPROVED BY MEMBERS OF THE THESIS COMMITTEE:

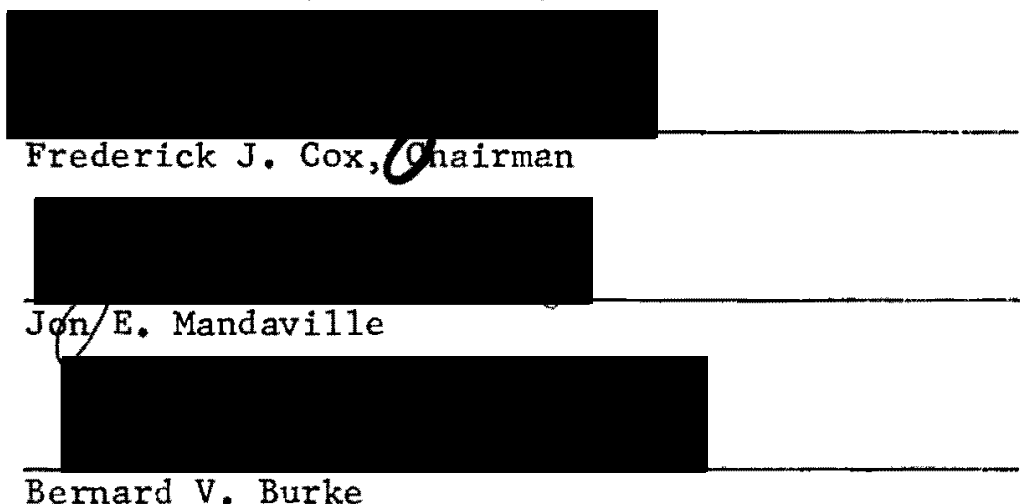

The main objective of American foreign policy in the Middle East, during the post-War period of 1946-1958, was to safeguard the area against Soviet intrusions. This thesis attempts to examine the causes for the failure of the United States to achieve this objective. It concludes that this failure is the result of an alienation of the major national forces in the Middle East. The United States alienated the Arab world by openly and unreservedly supporting Zionist aims in Palestine. She alienated newly independent states by establishIng close cooperation with Britain and France, their former colonial masters. She alienated revolutionary nationalists by supporting reactionary and traditional rulers against them and by opposing their ideals of neutrality and revolutionary change. In doing so, the United States opened the way for the Soviet Union to challenge her position and threaten her interests in the area. By emphasizing the 
military aspects of containment, she demonstrated a lack of understanding of the nature of the Soviet threat. The revolutionary nationalists sought to obtain military, economic, and technical aid without conditions or political strings. By insisting on imposing her conditions of alliance against communism and securing concessions and guarantees, including the safety and security of Israe1, the United States made it impossible for the nationalist forces to cooperate with her. They, therefore, were forced to dea1 with the Soviet Union, whose aid was offered with no conditions or strings attached. The American response to isolate and weaken those states which accepted Soviet aid, through such means as the Eisenhower Doctrine, brought on a most serious deterioration in relations never before encountered by the United States and the most spectacular successes ever realized by the Soviet Union in the Middle East. 


\section{THE POLICY OF CONTAINMENT AND}

THE MIDDLE EAST

1946-1958

by

AHED GEORGE SAMAAN

A thesis submitted in partial fulfillment of the requirements for the degree of

\section{MASTER OF ARTS}

in

HISTORY

Fortland State University

1972 
TO THE OFFICE OF GRADUATE STUDIES:

The members of the Committee approve the thesis of

Ahed George Samaan presented July 28, 1972.

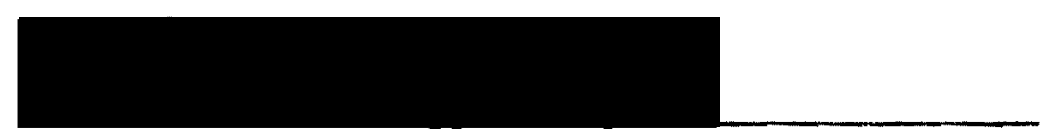

Frederick J. Coy,/Chairmán

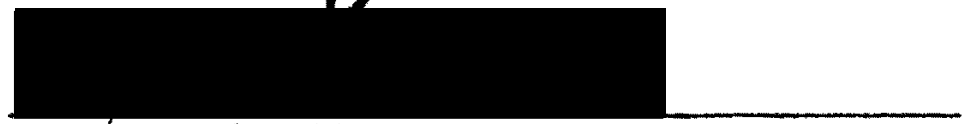

Jon E. Mandaville

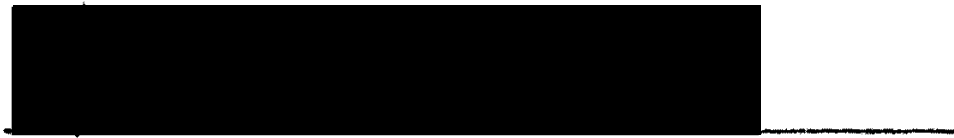

Bermard V. Burke

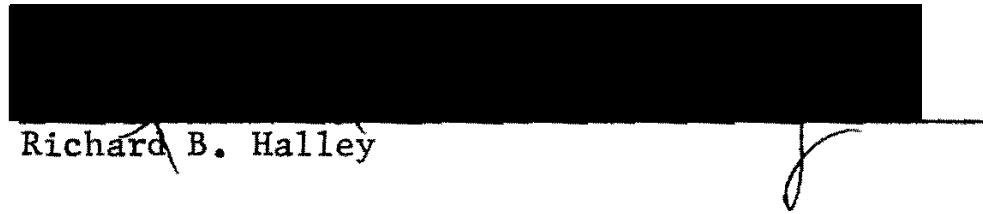

APPROVEL :

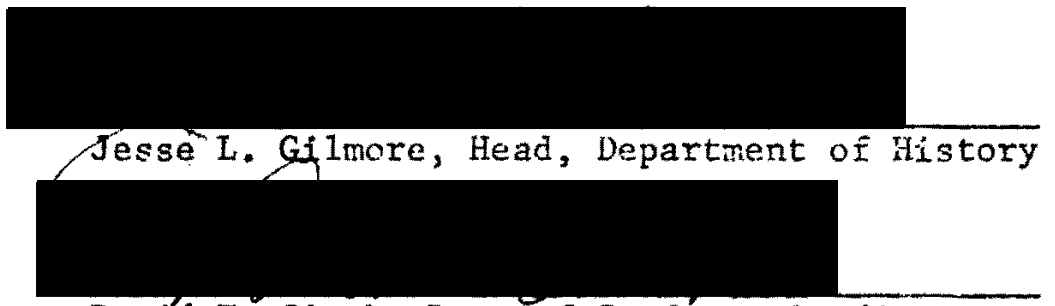

David T. Clark, Dean of Gradiate Studies

July 28,1972 
TABLE OF CONTENTS

PAGE

FOREWORD

PART I. CONTAINMENT: THE TRUMAN YEARS

\section{CHAPTER}

I THE CASE OF IRAN

II THE CREATION OF THE STATE OF ISRAEL ............ 51

III THE ALIENATION OF THE ARAB WORLD ............ 77

PART II. CONTAINMENT: THE DULLES ERA

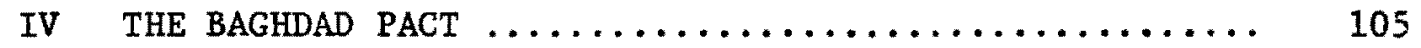

V THE RUSSTAN ARMS DEAL ................... 126

VI THE SUEZ CRISIS $\ldots \ldots \ldots \ldots \ldots \ldots \ldots \ldots \ldots \ldots \ldots \ldots \ldots \ldots$

VII THE EISENHOWER DOCTRINE .................. 195

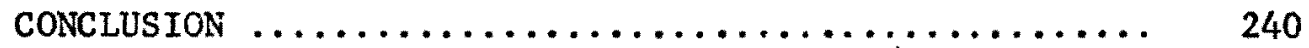

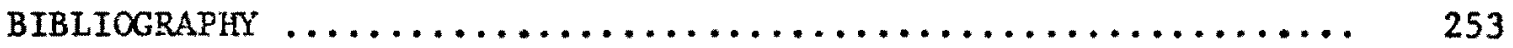


FOREWORD

The term "Middle East" is an elastic one. It is meant here to cover an area that includes Turkey, Iran, Iraq, Jordan, Syria, Lebanon, Israe1, Egypt, Libya, Sudan, Saudi Arabia, Kuwait, Yemen, and the smaller states of the Arabian Peninsula.

In this study, Arabic names have been rendered in forms most commonly used by scholars in this field, except where difficulty was encountered in deciding what the common form was; there the Library of Congress transliteration rules were applied.

The bibliography at the end of this study does not include all sources consulted. Only those publications actually cited are listed. Translations from Arabic sources are my own. The responsibility is mine for any imperfections or mistranslations the reader might detect. I am grateful to Dr. Frederick J. Cox for his critical reading of my manuscript. Needless to say, responsibility for its remaining shortcomings is mine alone. I am also indebted to the History Department and the Middle East Studies Center of Portland State University for making it possible for me to pursue this piece of research work. The former awarded me a Graduate Assistantship for the school year 1971-1972, and the 1atter paid for photocopies of journal articles obtained through the Portland State University Library "Inter-1ibrary Loan" service. My thanks go to Ms. Lee Cummins for typing this thesis and to Ms. Karen Waters for her assistance and help. 


\section{INTRODUCTION}

In h1s Farewel1 Address to Congress on September 17, 1796, outgoing President George Washington gave the following advice:

The grèat rule of conduct for us in regard to foreign nations is, in extending our cormercial relations to have with them as little political connections as possible.... Europe has a set of primary interests which to us have none or very remote relation. Hence she must be engaged in frequent controversies, the causes of which are essentially foreign to our concerns.... Our detached and distant situation invites and enables us to pursue a different course.... Why forego the advantage of so peculiar a situation? Why, by interweaving our destiny with that of any part of Europe, entangle our peace and prosperity in the toils of European ambitions, rivalships, interests, humor, or caprice? ${ }^{1}$

Washington's policy of detachment (i.e. non-entanglement, non-involvement, or 1solationism) set the tone of American forelgn policy for years to come.

The traditional policy of non-Involvement served the United States well in her developmental era. The founding fathers adopted 1t because it was politically advantageous. Being young and weak, the United States saw the wisdom of minding her own business and sroiding entanglement in the problems and quarrels of other nations. The policy was formulated for the sole purpose of serving the national Interests of the United States. Adherence to It, therefore, was applicable only insofar as it served those interests. In other words,

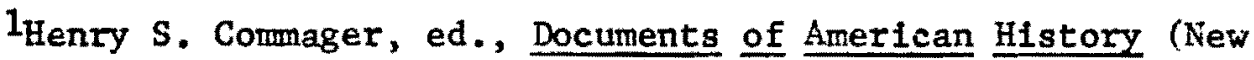
York: Appleton-Century-Crofts, 1949), p. 174 . 
Intervention was permitted when the safety and security of the United States demanded it.

The United States did actur.11y Intervene when Intervention was considered to be the most effective means of protecting the national Interests. The Interventions to achieve territorial expansion, to curb hostile neighbors, 1 and to subdue the priates of Barbary, were manifestations of such an interpretation of the traditional policy. The Barbary pirates presented a serious threat to American merchant vesse1s. Beginning in the early $1780^{\prime} \mathrm{s}$, the United States tried, through the payment of ransom for captured sailors and ships and through treaties, to guarantee the safety of her merchant fleet. But when, after nearly two decades, such arrangements proved ineffective, the United States began a series of naval attacks in 1800 against uncooperative Barbary states, culminating in a great show of force In 1804 as most of the United States Navy assembled in the Mediterranean to put an end to piracy, to curb the Barbary rulers, and to open the way to the eastern Mediterranean region. 2

Nevertheless, the policy of non-intervention was stated in such a way as to make it appear as though intervention would never be

${ }^{1}$ The interventions in Florida, Texas, and California are good examples; see Thomas A. Bailey, A Diplomatic History of the American 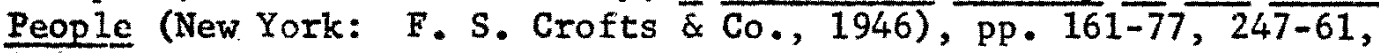 264-75; Samuel F. Bemis, A Diplomatic History of the United States (New Fork: Holt Rinehart and Winston, Inc., 1967), pp. 186-95, 219-31, 235-37.

2 James A. Field, Jr., America and the Mediterranean World, 17761882 (Princeton, N.J.: Princeton University Press, 1969), pp. 29-42, 51-53; Harold and Margaret Sprout, The Rise of American Nava1 Power, 1776-1918 (Princeton, N.J.: Princeton University Press, 1967), pp. 17, 25-49, 55-57. 
employed, no matter what the provocation. The absolute terms of the policy were meant to blunt public pressure and prevent it from attempting to push the United States government into a conflis: with a foreign power when it was deemed unnecessary or not in the best interest of the United States. Had its terms been conditional, the conditions would have allowed for all kinds of interpretations. 1 Thus, despite American public pressure to force the United States government to aid the Greeks in the $1820^{\prime} \mathrm{s}$, the Bulgarians in the $1870^{\prime} \mathrm{s}$, and the Armenians in the $1890^{\prime}$ 's against the Ottoman Turks, the United States government kept out of those conflicts.

As the United States grew stronger, the traditional policy was occastonally reconsidered and modified. In his inaugural address in 1857, President James Buchanan said, "IThe United States $\bar{T}$ ought to cherish a sacred regard for the independence of all nations, and never Interfere in the domestic concerns of any unless this shall be imperatively required by the great law of self-preservation."2 The requirements of "the great law of self-preservation" opened the way for a wider latitude in interpretation. On the basis of such a rendition of the traditional policy, President Ulysses Grant embraced

${ }^{1}$ Doris A. Graber, "The Truman and Eisenhower Doctrines in the Light of the Doctrine of Non-intervention," Political Science Quarterly, LXX (September, 1958), 324-26.

2 James Daniel Richardson, comp., A rompilation of the Messages and Papers of the Presidents, 1789-1897 (10 vols.; Washington, D.C.: Government Printing Office, 1902), IV, 2966. 
the Idea of annexing Santo Domingo to turn it into a naval base. This profect drew strong protests from his opponents in the Congress. A pruposal to annex Santo Domingo was defeated by the Congress in 1870.1 Following the Spanish-American War, the category of objectives for which intervention was deemed permissible was further broadened to include, among other things, the economic interests of American citizens in foreign countries. It also became no longer imperative to ascertain the necessity for intervention in each case. The danger did not need to be immediate; potential danger was sufficient to justify intervention. The door became wide open for much more Iiberal interpretations of the traditional policy. Such liberal interpretations led to the inevitable misuse of the policy to interfere in the affairs of other nations at times when a threat to American interests was seen as a future possibility. President Woodrow Wilson came to correct such misuse of the pollcy. ${ }^{2}$ In the words of Doris Graber, member of the Center for the Study of American Foreign and Military Policy at the University of Chicago,

He declaimed against a policy of unbridled and unprincipled power and deplored advancing American welfare wantonly at the expense of other nations. He returned to a concept of a severly limited right of intervention in wich the definition of "vital" Interests which might be defended by intervention was even narrower than in the days of the founding fathers..... Wilson resorted to intervention only when, in his opinion, the military security of the United States made a less drastic course impossible. 3

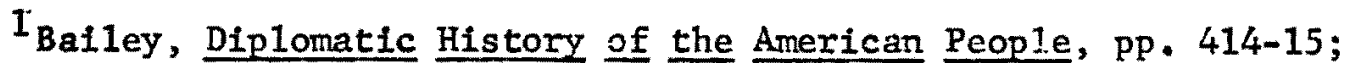
Bemis, Diplomatic History of the United States, pp. 403-404.

${ }^{2}$ Graber, "The Truman and Eisenhover Doctrines," pp. 326-28. ${ }^{3}$ Ibid., p. 328. 
But it was none other than President WIIson who led the United States into her first major intervention by actively participating In the first global war. Since 1815, an agreement with Britain enabled the United States to enfoy protection of her trade on the high seas. Britain's renunciation of territorial ambitions in the Americas and the balance of power in Europe guaranteed U.S. supremacy in the western hemisphere and her own security. However, toward the end of the nineteenth century, the power balance in Europe was disturbed by the rise of Germany and by the threat of realizing her ambitions in Europe. "No one in America had anticipated this," observed Walter Lippmann, "and few were prepared to understand this. The nation had always faced towards the west. Now it had to turn around and to recognize that there was a great threat from the rear where all had so long been secure." 1

It was not easy to change the traditional attitude. It was as difficult for Americans to comprehend the role played by external forces in affecting the safety and security of the United States. "They had become so accustomed to their security," says George Kennan,

that they had forgotten that it had any foundations at a11 outside our continent. They mistook our sheltered position behind the British fleet and British continental diplomacy for the results of a superior American wisdom and virtue in refraining from interfering in sordid differences of the old world. And they were oblivious to the first portents of the

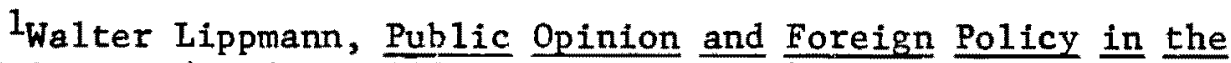
United States (London: A1len \& Unwin, 1952), p. 23. 
changes that were destined to shatter that pattern of security in the course of the ensuing half-century. 1

The United States entered World War I primarily to prevent

Germany from becoming sole master in Europe. The justification for Intervention given by President Wilson was based on legal and moral arguments. He did not make it sufficiently clear that it was in the national interest of the United States to enter the War. Americans were, therefore, confused. According to Walter Lippmann,

Because - . American interest was not candidly made explicit, the nation never understood clearly why it had entered the war - . the country was . . open to every suggestion and insinuation that the nation had fought for no good reason at al1, that it had been maneuvered into a non-American war by the international bankers and the British diplomats. And so, having failed to make plain that the war was waged for a vital American interest, President Wilson had no way of proving to the nation that his settlement of the war really concerned the United States. 2

Consequently, the idea of collective security was discarded, the League of Nations wes abandoned, and internationalism was subordinated to traditional isolationism until World War II. Besides, the need for the United States to intervene after World War I declined because enemies and rivals were exhausted by the war and reduced to temporary impotence. The reversion to isolationism did not last for long, however. The rise of Hitlerism in the mid 1930's and similar aggressive authoritarian states in Europe and Asla disturbed the

${ }^{1}$ George F. Kennan, American Diplomacy, 1900-1950 (Chicago: University of Chicago Press, 1951), p. 5.

Walter Lippmann, U.S. Foreign Policy: Shield of the Republic (Boston: Little, Brown and Company, 1943), pp. 37-38. 
the temporary peace. President Frank1in D. Roosevelt considered the domination of Europe and Asia by two expansionist and totalitarian regimes a serious enough threat to America's territorial integrity and national independence to justify intervention against Germany and Japan. The United States first extended military and financial aid to those nations resisting the Axis powers, but eventually became an active belligerent in the war against them.

American participation in World War II campaigns in the Middle East helped establish direct contact between American and Middle Eastern officials. The reputation of the United States as a supporter of popular independence movements created a congenial and favorable atmosphere for her to further her interests and establish meaningful friendships with the area's peoples.

In fact, America's relations with the Middle East go back much further. American commercial contacts with the area began in the late eighteenth century. Barbary piracy and European resistance, however, discouraged the growth of U.S.-Mideast trade. American rum, grain and fish were in great demand in the Levant. Smyrna raisins were shipped to the United States as early as 1785. Turkish figs and opium were also traded. Opium was the principal commodity and essential to America's China trade. American skills and naval architecture excited the rulers of Barbary and aroused the interest of the Ottomans. America's non-involvement in European feuds made her merchant fleet a useful neutral carrier. Her remoteness and her policy of non-entanglement made her all the more desirable as a friend. Her forceful intervention in Barbary cane as a last resort. Once the 
Barbary rulers were curbed, the way to the Levant was open. As a result, American commerce penetrated the region and expanded vigorously. 1

The eastern Mediterranean region, however, had, toward the end of the elghteenth and the beginning of the nineteenth centuries, become subject to international rivalries and interferences. Russia's appearance in the region in the eighteenth century was followed by the Napoleonic expedition into Egypt and southern Syria. Mohammed Ali rose against the Ottoman Sultan and established his own state in Egypt. The Greeks revolted against the Ottomans. Russia's interest in the Turkish straits was displayed in a provocative advance toward Constantinople--a move that drew the British and the French into the political arena of a decaying Ottoman Empire. American missionaries began their work in the area early in the nineteenth century. The growth and success of their work required the necessary protection of the American government when such protection was not provided by the British. 2

A formal treaty was concluded between Turkey and the United States on May 7, 1830, which was followed by an unofficial American naval mission to Turkey to help build new warships and modernize the

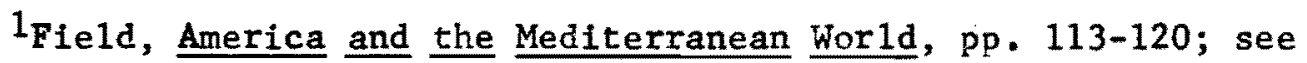
a1so, Leland J. Gordon, American Relations with Turkey, 1830-1930: An Economic Interpretation (Philadelphia: University of Pennsylvania Press, 1932).

2Robert L. Danie1, American Philanthropy in the Near East, 1820-1960 (Athens: Ohio University Press, 1970); Field, America and the Mediterranean world, pp. 104-140, 176-213. 
Turkish navy. A similar mission operated in Egypt beginning in the late $1860^{\prime} \mathrm{s}$ and did not leave until pressured out by the European powars and the Ottoman Sultan in the early $1880^{\prime} \mathrm{s}$. One of the nost outstanding accomplishments of this latter mission were the geographical surveys it produced, especially of the Sudan. ${ }^{1}$

Perhaps the most significant manifestations of American interest in the Middle East were the religious, educationa1, and philanthropic activities of American missionaries. They founded we11-known and influential American educational institutions in the area such as Robert College of Istanbul in 1863, the American University of Beirut in 1866, and the American University at Cairo in 1919. Through their presses in Istanbu1 and Beirut, they encouraged education and modernization through reading. The presses produced school manuals, textbooks, and general reading materials. The missionaries encouraged the revival of Arabic literature and tradition, stimulated the growth and directed the course of national movements in the Middle East. ${ }^{2}$

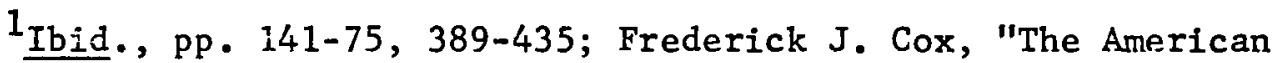
Naval Mission in Egypt," The Journal of Modern History, XXVI (June, 1954), pp. 173-78; Pierre Crabites, Americans in the Egyptian Army (London: G. Routledge \& Sons, Ltd., 1938).

2Danie1, American Philanthrophy in the Middle East, pp. 1-225; Albert Habib Hourani, Arabic Thought in the Liberal Age, 1798-1939 (London: Oxford University Press, 1962), pp. 95-102; Fie1d, America and the Mediterranean World, pp. 92-103, 153-65, 176-206, 262-305, 345-59; see a1so, David H. Finnie, Pioneers East: The Ear1y American Experience in the Middle East (Cambridge, Mass.: Harvard University Press, 1967); Roa Humpherys Lindsay, Nineteenth Century American Schools in the Levant: A Study of Purposes (Ann Arbor: University of Michigan Press, 1965); Julius Richter, A History of Protestant Missions in the Near East (New York: Fleming H. Revel1 Company, 1910); Abdul Latif Tibawi, American Interests in Syria, 1800-1901 (Oxford: Clarendon Press, 1966). 
When President Wilson announced his Fourteen Points (point 12 concerned the Middle East) during World War I in support of national self-determination, ${ }^{1}$ the people of the Miadle East saw him as an ally. A resolution by the General Syrian Congress on July 2, 1919 declared,

We rely on President Wilson's declaration that his object in entering the war was to put an end to acquisitive designs for imperialist purposes. In our desire that our country should not be made a field for colonisation and in the belief that the American President has no political designs on our country, we resolve to seek assistance . . . from the United states of America. - for help in the fulfilment of our hopes. ${ }^{2}$

The King-Crane Commission, sent to Syria by President Wilson to ascertain the national aspiration of the Arab peoples, reported on August 28, 1919, "Our survey left no room for doubt . . Lthat $\bar{T}$ America was the first choice Las mandatory $\bar{T} . " 3$ The King-Crane Commission also revealed that Iraq too chose "America as mandatory, and with no second choice." 14

In regard to the Palestine question, the Commission reported that there was strong opposition in Syria to the idea of a Jewish State in Palestine. 5 The Commission's report, however, remained a secret until portions of it were published in 1922. It is believed

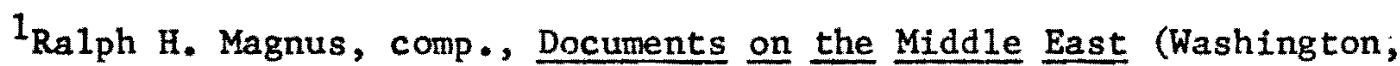

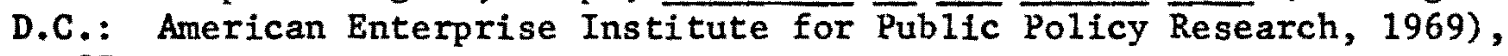
P. 27.

${ }^{2}$ George Antonius, The Arab Awakening (New York: G. P. Putnam's Sons, 1946), Pp. 441-42, Appendix G.

3 Magnus, Documents on the Middle East, p. 35.

'Antonius, The Arab Awakening, P. 457, Appendix H.

5 See, Magnus, Documents on the Middle East, p. 33. 
that Zionist pressures were the primary cause for the suppression of the KIng-Crane report. 1

Unt11 the peace settlement 3 of 1922, America's primary interests in the area were humanitarian and educational interests, not economic or political. Significant economic interests developed after the discovery of oil in the Middle East. ${ }^{2}$ As America's share in Middle East ofl increased, her interests in the political affairs of the area also Increased. By 1942, the United States share in Middle East oil grew to 42 percent. 3

After World War II and before the United States reverted once more to isolationism, she found herself threatened by Soviet communism. The United States had the choice either to allow world events to take their natural course or to use her power to defeat conmunism. The argument for the first choice was that, by staying out, the U.S. would preserve her strength and leave communism to defeat itself or be weakened by its victims. Should communism spread around the world, however, then the United States would fight it whenever it attacked the western hemisphere. The argument for the latter choice was that, once communism spread around the world, it would be too late to fight it. Therefore, the United States should immediately intervene to halt its advance anywhere and everywhere in the world.

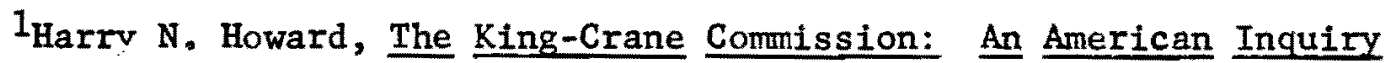
In the Middle East (Beirut: Khayat, 1963), p. 311.

2 See, Magnus, Documents on the Middle East, pp. 40-42.

3John A. DeNovo, American Interests in the Middle East, 19001939 (Minneapolis: University of Minnesota Press, 1963), pp. 167-209. 
It was George Kennan, then charge d'affaires in Moscow, who was instrumental in formulating the policy based on the latter argument. In a telegram from Moscow, dated February 22, 1946, he wrote,

Soviet power.. does not work by fixed plans. It does not take unnecessary risks. Impervious to logic of reason, and it is highly sensitive to logic of force. For this reason it can easily withdraw--and usually does--when strong resistance is encountered at any point. Thus, if the adversary has sufficient force and makes clear his readiness to use it, he rarely has to do so. 1

In his book, American Diplomacy, 1900-1950, Kennan says that the "main concern" of Soviet policy "Is to make sure that it has filled every nook and cranny available to it in the basin of world power. But if it finds unassailable barriers in its path, it accepts these philosophically and accommodates itself to them." Therefore, "the main element of any United States policy toward the Soviet Union must be that of a long-term, patient but firm and vigilant containment of Russian expansive tendencies." 2

Rennan advocated the Implementation of containment of Soviet communism through,

the adroit and vigilant application of counterforce at a series of constantly shifting geographical and political points, corresponding to the shifts and maneuvers of Soviet policy . . to confront the Russians with unalterable counterforce at every point where they show signs of encroaching upon the interests of a peaceful and stable wor $1 d .3$

$1_{\text {U.S., Department of State, Foreign Relations of the United }}$

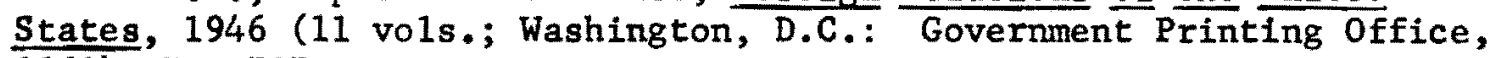
1969), VI, 707.

2Kennan, American Diplomacy, 1900-1950, pp. 118-19.

$3 \times$ George F. Kennañ Affairs, $\mathrm{XXV}$ (July, 1947), 576-81. 
In relation to the Middle East, the United States attempted to implement the polfcy of containment through warnings, threats, pacts and alliances, treaties, technical and financial aid programs. This was done first in cooperation with Britain and France before the United States gradually began to replace them in the area. The Truman Doctrine, announced on March 12, 1947, was meant to fill the power vacuum created by the British decision to quit Greece and Turkey. "Specifically," says Ralph Deans, "the Truman Doctrine put the United States in the traditional British role of preventing Russian expansion Into Turkey and Greece."1

Thus, instead of reverting to isolationism, the United States accepted her new international responsibilities. U.S. policy planners had apparently decided that American security and national interest demanded that world responsibilities be shouldered. America's basic policy of non-involvement and non-intervention was replaced by a dynamic policy of full involvement and full intervention as she assumed full responsibility for the balance of power in the world. What becomes evident, therefore, is that America was content all along to let the European powers manage the balance of power and fill power vacuums in the world while "Fortress America" remained sheltered in isolationism, but when those powers gave way and America saw a threat to her security, she was ready and willing to assume their role. The apparent change in policy is not, therefore, a reflection of a basic

1Ralph C. Deans, "American Policy in the Middle East," Editorial Research Reports, II (August 19, 1970), 616. 
change in the American character, but in the world situation. The Monroe Doctrine was simply extended to cover the whole world. 
PART I. CONTAINMENT: THE TRUMAN YEARS

\section{CHAPTER I}

\section{THE CASE OF IRAN}

Before World War II, the relationships between the United States and Iran on the government level were relatively insignificant. On the private leve1, however, missionaries and other American private citizens had expended money, time and effort in various constructive activities, creating a great deal of good will among Iranians toward the United States. The fact, too, that the U.S., unlike Russia and Britain, had not interfered in Iran's internal affairs and had not shown territorial ambitions in their country, impressed Iranians. The United States considered Iran in the British and Russian sphere of influence, which she was determined not to trespass.

Following the outbreak of World War II, Iran came more and more Into contact with the United States. Britain, under the strain of the War, called upon U.S. assistance in getting supplies to Russia through the so-called "Persian Corridor." The U.S. formed the Persian Gulf Service Command, composed of some 30,000 troops to serve in the Corridor in a technical capacity and to see to it that the necessary war materials were delivered to Russia. Under American Lend-Lease aid, Iran got an American army mission under General Clarence Ridley, a police mission under Colonel H. Norman Shwartzkopf, and an economic mission under Dr. Morgan Millspaugh. Dther arrangements were made for 
additional American experts to work under individual contracts in Iran.

A11 this was done in the absence of a real American policy toward Irax. The Tripartite Treaty of 1942, between Iran, Britain, and Russia, provided for Allied troop withdrawal within six months after war hostilities ceased. Toward the end of the Teheran Conference in 1943, the Big Three issued the Teheran Conference Declaration (December 1, 1943), thanking Iran for her services, promising economic assistance after the war, and reaffirming their interest in guarding Iran's territorial integrity and maintaining her independence and sovereignty. By the end of the War, Iranians had been greatly impressed by the attitude, behavior, and work of American troops, technicians, advisers, and missionaries. They hoped the U.S. would provide more experts, increase her material assistance and, eventually, attempt to offset Russian and British influence in Iran.

\section{THE AZERZAIJAN CRISIS}

On May 8, 1945, Germany surrendered; Russia had not yet decided to enter the war against Japan, and Iran was declared an inactive theater. The Iranian government, therefore, requested that the Allied troops be withdrawn from her territory. 1 The United States declared her intention to comply with the Iranian request and began to withdraw her troops in June. 2 Russia reminded Iran that Allied forces did not

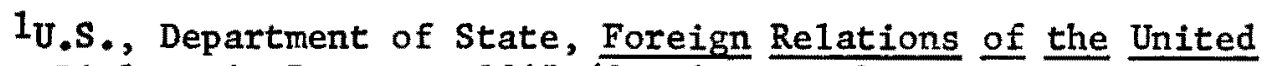
States, Diplomatic Papers: 1945 (9 vols.; Washington, D.C.: Government Printing Office, 1967-69), VIII, 369-74.

2 Ibid., 378. 
have to leave until six months after the end of hostilities, in accordance with the Tripartite Treaty of 1942. The United Kingdom expressed her willingriess to withdraw, prorided the Russians did. 1 The issue was discussed in July during the Potsdam Conference, but Stalin maintained his position. He promised, however, that no action would be taken by the Soviet Union against Iran. ${ }^{2}$

In August, while the matter of withdrawal was still being debated, the Azerbaijan crisis erupted. Under the name Democrat, the Tudeh party, supported by Soviet troops, attempted to gain control of Tabriz and the area around it and called for administrative autonomy of the province of Azerbaijan. Several new divisions of Soviet troops entered the area in October in support of the Tudeh party, followed in November by a second attempt to seize power. Iranian troops were dispatched to quell the rebellion, but Russian troops prevented them from doing so. The Tudeh declared the Autonomous Republic of Azerbaijan on December 12, 1945, and an Iranian Communist, Ja'afar Pishevari, was appointed Premier. This was followed by a Kurdish rebellion in Western Azerbaljan and the creation of the Kurdish People's Republic on December $15,1945 .^{3}$

The formation of those two independent republics separated

1 Ibid., $362,374,413-14$.

2Harry S. Truman, Memoirs (2 vo1s.; Garden City, N.Y.: Doubleday, 1955-56), I, 379-80.

3Michael KahI Sheehan, Iran: The Impact of United States Interests and Policies, 1941-1954 (Brooklyn, N.Y.: Theo. Gaus' Sons, 1968), p. 28 . 
Azerbaljan from the control of the central government of Iran. A11 Iran could do was to send protest notes to the Soviets and appeal for American support. The U.S. response was to give serious thought over reconsidering her position. It was the Azerbaljan crisis that set the U.S. on the courge which led to the policy of containment. On November 24, 1945, the U.S. sent one of the first strong notes of protest to the Soviet Union arging early evacuation of allied troops from Iran. 1 The call for withdrawal was rejected by the Soviet Union. Instead the Sovfets insisted on staying in Iran until the Treaty deadline of March 2, $1946^{2}$ (a date agreed upon by Bevin and Molotov at the London Conference of Foreign Ministers). A further warning came from Secretary Byrnes to Stalin during the Allied Foreign Ministers Conference in Moscow in December 1945 to the effect that, should Iran take the matter to the U.N., the U.S. would back Iran, and that Stalin should try to avert this dispute with the U.S. Stalin replied that the "Soviet Union was not afraid of having the Iran question raised at UNO." 3

When no agreement was reached between Stalin and Byrnes, and after U.S. protests were rejected, the Iranian government brought the problem before the U.N. Security Council in January 1946, formally

\section{${ }^{1}$ Foreign Relations...: 1945 , VIII, 448-50.}

${ }^{2}$ Trumdn, Memoirs, II, 93; Andre Fontaine, History of the Cold War from the October Revolution to the Korean War, 1917-1950 (New York: Random House, 1968), P. 282. 518.

${ }^{3}$ Truman, Memoirs, II, 94; Foreign Relations...: 1945, VIII, 
charging the Soviet Union with Interference in Iran's Internal affairs. Following some discussion on the issue, the Security Council decided to have Iran and the Soviet Union make a try at sett1ing the iispute between themselves and report the results to the Council. I Ahmad Qavam, the Iranian Prime Minister, began his talks with the Soviets on February 19, 1946. No agreement was reached. The withdrawal date of March 2 was anxiously watched by the U.S., Great Britain and Iran. On March 1, 1946, Russia announced a partial withdrawa1 starting March 2, from three areas; her troops would remain in the other areas pending improvement in the Iranian situation. Another strong note was sent to Russia by the U.S. on March 6, 1946:

The decision of the Soviet government to retain Soviet troops in Iran beyond the Period stipulated by the Tripartite Treaty has caused a situation to which the United States . . - as a party to the Declaration Regarding Iran dated December 1,1943 , cannot remain indifferent. 2

To this was added "the earnest hope that the Government of the Soviet Union wi11 do its part, by withdrawing immediately al1 Soviet forces from the territory of Iran." 3

The response to this note was the exact opposite of what the U.S. expected, or hoped, the Soviet Union would do. Instead of withdrawing immediately, the Soviets ordered additional troops into Iran and, according to reports received by President Truman,

1Fontaine, Co1d War, 1917-1950, p. 283.

2U.S., Department of State, Bu1letin, XIV (March 17, 1946), 435. 3rbid., 436. 
Three major Russian columns were reported on the march, one toward the capital city of Teheran, another swinging toward the Turko-Iranian border. The signs were plain that Russia was determined to have her way and that she intended to ignore the U.S. and the U.N. alike. 1

There was strong suspicion in Iran that Russia and her agents had planned a coup d'etat. 2 The U.S. government was alarmed and, expecting trouble, ordered her embassy personnel to be ready to leave the capital to the South on a moment's notice. 3 While this tension gripped Iranians and their goverment, the U.S. urged Iran to refer the matter back to the U.N. On March 18, 1946, Iran did so and charged Russia with aggression.

The expected coup did not take place, however. Instead Russia made a surpirse announcement on March 24, while the matter was still being debated at the U.N. The announcement revealed that an agreement was reached between Iran and Russia, according to which Russian troops were to be withdrawn within six weeks from Iran; the dispute was to be dropped by the U.N.; the Azerbaijan crisis would be considered an Internal affair of Iran; and a Joint-Stock Soviet-Iranian 011 Company, in which Russia would hold fifty-one percent of the stock, would be established. In harmony with a law passed by the Iranian Majlis on

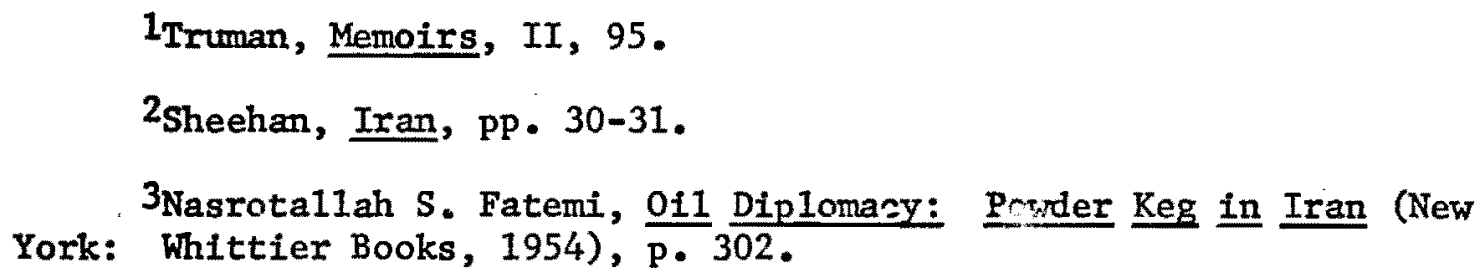


December 2, 1944, whose author was Dr. Mohammad Mossadegh, 1 the oil treaty was subject to ratification by the Majlis within seven months following its election. Accordiug to George Lenczowski, Qavam was "acting under duress" when he made these "three important concessions to Russia."2 Secretary of State Byrnes insisted, however, that the Security Council adopt a resolution (and it did) to the effect that, if the Soviets did not show signs of carrying out their promise of withdrawal by May 6 , the Security Council withheld the right to take up the question once more. By May 9 a11 Russian troops had departed and Iranian troops entered Azerbaijan in December despite Russian and Tudeh objections and protests. The two republics collapsed in the same month and Azerbaijan was reincorporated into the rest of the country. A purge of the Tudeh party was soon underway. In his book, Present at the Creation, Dean Acheson records that,

Ambassador George Allen cabled on December 17, 1946, that in the Iranian view the quick collapse of the Tudeh Party was due to the comviction of everyone--the Russians, the Iranians, and the Azerbaijanis--that the United States was not bluffing but solidly supporting Iranian sovereignty. 3

The Russian decision to withdraw was not at all expected, because all indications showed that they were intent on staying and bent upon

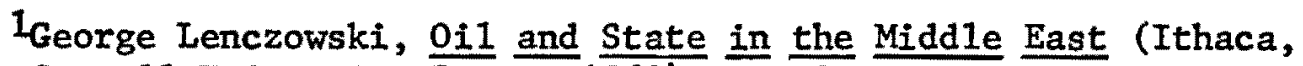
N.Y.: Corne11 University Press, 1960), p. $\overline{90 .}$

${ }^{2}$ George Lenczowski, The Middle East in World Affairs (3rd ed.; Ithaca, N.Y.: Corne11 University Press, 1968), p. 195.

3Dean Gooderham Acheson, Present at the Creation: My Years at the State Department (New York: Norton, 1969), p. 198. 
bringing about a change in the Iranian government. What was it, therefore, that made them suddenly decide to withdraw? It was revealed later that U.S. support to Iran ras much stronger than it appeared to have been on the surface. On April 24, 1952, President Truman stated that he and his State Department had come to the conclusion, as early as 1946, that the only thing the Russians understood or respected was force or the threat to use it. The fallure of the Moscow Conference, the Russian refusal to heed warning, and the sending of additional troops and military equipment into Iran caused the U.S. serious alarm. The "Iron Fist" approach was to be used with Russia, concluded President Truman, or the free world could expect another war. Truman declared, "I had to send an ultimatum to the head of the Soviet Union to get out of Persia."1 The President went further to say that, "It was a message from me to Stalin to get out of Persia. Unless he did get out, we would put some more people in there. $"{ }^{2}$ The President was ready to "take the necessary steps, if he did not get out. And we had a fleet at that time in the Persian Gulf, and we had a lot of soldiers over in that neighborhood." 3 In his memoirs, however, President Truman does not use the word ultimatum; Instead he just says, "I told Byrnes to send a blunt message to

${ }^{1}$ U.S., President, Public Papers of the Presidents of the United States (Washington, D.C.: Office of the Federal Register, National Archives and Records Service, 1945-), Harry S. Truman, 1952, p. 291.

2Ibid., p. 294 .

3Ibid. 
Premier Stalin." 1

If Truman's claim is true, a tough pollcy toward Russia was adopted as early as March 1946, which had at its core the spirtt of the Doctrine of Containment of communism. Therefore, it can be argued that the Truman Doctrine was conceived not in March of 1947, but a year earlier. It had its beginning not in Greece, but in Iran. It was this policy, then, that caused the rumored Russian-supported coup to fail and brought Russia to make that unexpected withdrawal announcement. But the victory for Iran was not total. There still remained the undesirable oil treaty with Russia. Had the Iranians been aware of the tough American stand, the oil agreement would, perhaps, never have been reached. Nevertheless, it still needed to be ratified by the new Majlis before it went into effect. But before the new Maj1is met for the first time, several things had taken place, which were to significantly influence its decision.

In the fall of 1946, the United States made known her support to Turkey against Soviet demands for exclusive control of the Dardanelles by the Black Sea powers and for cession of Turkish territory in eastern Anatolia. In regard to the Straits, the United States declared on October 9, 1946, that

The Govermment of Turkey should continue to be primarily responsible for the defense of the Straits and that should the Straits become the object of attack or threat of attack by an aggressor, the resulting situation would be a matter for action on the part of the Security Council of the United Nations. 2

$1_{\text {Truman, Memoirs, II, } 95 .}$

${ }^{2}$ U.S., Department of State, Bulletin, XXV (November 19, 1951), 811; see also U.S. News (August 30, 1946), pp. 16-17. 
On March 12, 1947, President Truman announced the Truman Doctrine, declaring readiness on the part of the U.S. government to contain commmism in all the world, to support nations threatened by communism, and to grant specified financial grants to Greece and Turkey.1 Iranians welcomed the Truman Doctrine even though Iran was not specifically mentioned in it. The Doctrine definitely covered Iran and, to the Iranians, was an official recognition and a concrete evidence of U.S. Interests in Iran. The creation of the Bureau of Greek, Turkish, Iranian Affairs as a unit of the U.S. Department of State $^{2}$ was a further expression of support to the Iranians, who took It to mean that their country was considered as important to the U.S. as Greece and Turkey. After a11, the Truman Doctrine was an outgrowth of American policy in Iran. The fading British influence in the area had to be replaced and Soviet expansionism contained, making U.S. policy in Iran only a part of a larger and wider policy to contain commmism, not only in Iran, Greece or Turkey, but in other parts of the world, and to strengthen non-communist countries against communism, Including Iran.

The Truman Doctrine was followed with the signing of an agreement on Jume 21, 1947, according to which the U.S. agreed to se11 Iran defensive weapons and military supplies. The Truman Doctrine and the military agreement gave the Iranians the strength to face the 1U.S., Department of State, BuIletin, XVI (March 23, 19-7),
34-37. 25heehan, Iran, P. 37. 
Russians with independence and force. This inspired courage was given greater impetus when on September 11, 1947, the U.S. Ambassador to Iran issued a policy statement to the effect that Iran was free to accept or reject any Russian offer and that she could count on U.S. support and backing. This had a distinct impact on the Majlis as it was preparing to accept or reject the oil treaty with Russia. A further assurance which was definitely designed to erase any remaining doubt, if there was any left, came a few days before the Majlis voted on the treaty in the form of an agreement between the U.S. Ambassador George Allen and the Iranian War Ministry, extending the services of the Army and Police missions until March 20, 1949, and 1imiting military advice to that provided by the U.S. advisers. ${ }^{1}$

On October 22, 1947, the Majlis rejected the treaty In spite of objections from the Tudeh party and from Russia. Prime Minister Qavam, who negotiated the treaty with the Russians, resigned. 2 But the strong American backing, the rejection of the treaty, and the ouster of Qavam naturally angered the Soviets and tensed relations between Russia and Iran. Russian hostility became so intense that Iranians began to be suspicious of another coup attempt. Iran received protests from the Soviet Union accusing her of hostile activity and of encouraging American influence, both military and otherwise, in Iran. ${ }^{3}$ The

1필., pp. 37-38.

2Richard Cottam, Nationalism in Iran (Pittsburgh: University of Pittsburgh Press, 1964), pp. 197-98.

${ }^{3}$ Lenczowski, Middle East in World Affairs, p. 197. 
United States was also warned and accused of trying "to transform Iran Into a military base to be used against the Soviet Union."I To give credence to Russian protests, th: Tudeh party held demonstrations to protest American influence.

But Iran could not be intimidated. U.S. support was open and strong. Russian pressure was successfully resisted with rare courage. ${ }^{2}$ The big neighbor and traditional enenry was firmly rebuffed and her agents and sympathizers were effectively dealt with, thanks to U.S. support, for without it the much-talked-about shrewdness of Qavam could not have saved Iran. In March of 1949, after the signing of the Atlantic Pact, Secretary of State Dean Acheson declared that the Pact was not meant to shift American attention from Greece, Turkey or Iran to Europe, but that "interest in the security of these countries has been made clear, and shall continue to pursue that policy."3 This statement was followed a few days later by the arrival of the first shipment of arms to Iran from the U.S.

\section{ATTEMPTS AT REFORM AND DEVELOPMENT}

With the cooling of the Azerbaijan crisis and with American support assured, Iranians were able to turn their attention to the more important objective of economic development. The internal

1U.S., Department of State, Bulletin, XX (April 3, 1943), 432.

2Lenczowski, Middle East in World Affairs, p. 196.

3U.S., Department of State, BuIletin, XX (March 27, 1949), 383. 
structure of the country needed overhauling. The Iranian government turned to the U.S. for help in planning and executing a seven-year development plan. 1 Two American compantes drew up the plan and advised on its implementation. The cost of the plan was estimated at $\$ 650$ million. 2 Since Iran could not completely finance the plan, a loan was to be sought. The financing of the plan had to come from ol1 revenues and from a foreign loan. If a foreign loan could not be obtained, the A.I.O.C. had to agree to increase the oil royalties. The greater the amount of funds available through a foreign loan, therefore, the less urgent it was to increase oil royalties.

Since the Iranian government believed that the U.S. would grant Iran a loan, the matter was simple, they thought. A11 they needed to do was to carry their case to Washington. No one could blame them for being so hopeful since the U.S. was spending billions of dollars to fight communism and effect a world economic recovery. Greece and Turkey were receiving generous amounts of aid. Besides, Iran was right on the doorstep of the communist camp. This type of logic filled the Shah with optimism and hope. When he arrived in the U.S. in November of 1949 to start a six-week official visit, it turned out that, in addition to the loan, he wanted more definite defense guarantees from the U.S. against aggression in the form of a treaty. Unfortunately, the Shah was disappointed. 3 As far as his objectives

1 Benjamin Shwadran, The Middle East: Oil and the Great Powers (New York: Praeger, 1955), pp. 171-72.

${ }^{2}$ Lenczowski, Middle East in World Affairs, p. 30. ${ }^{3}$ Cottam, Nationalism in Iran, p. 208. 
were concerned, his trip was a total failure. U.S. officlals were more interested in seeing Iran stamp out corruption and institute reform first. The Shah was so upset that he refused the courtesy of the presidential plane on his return trip. Iranian officials were confused; they could not figure out how the U.S. could refuse such a request when she was being such a good friend of Iran. 1 The Shah's failure in Washington caused great disappointment in Iran and dealt a serious blow to his prestige. ${ }^{2}$

The reason behind this American attitude was the belief that corruption prevailed in the Iranian administration. There was the fear that money lent would find its way into the pockets of Iranian public officials. The lesson of China was still fresh in the memory of U.S. officials, where money was poured generously into the coffers of the Kaumintang govermment; nevertheless, it collapsed because of corruption and lack of interest in reform. ${ }^{3}$ The U.S. was determined that any considerable loan to Iran would be granted only after corruption had been eradicated and reforms instituted. Besides, the U.S. did not want to give the impression that any promise to fight communism woul be rewarded with money. Another reason for the lack of enthusiasm on the part of the U.S., stated by Dean Acheson, was the feeling th: : "The seven year plan... [was $\bar{T}$ a grandiose

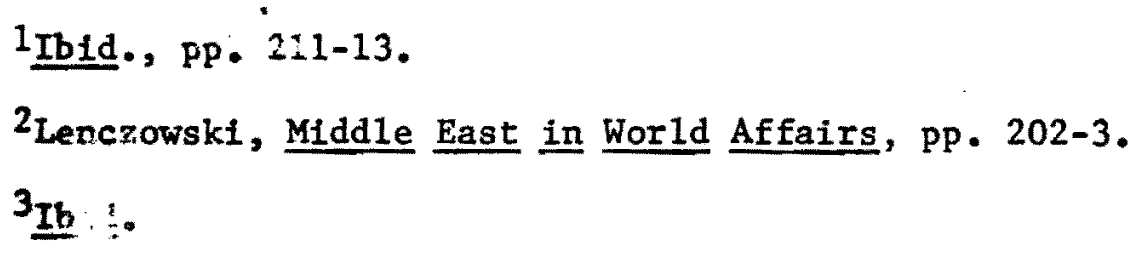


plan beyond the capacity of the Iranian government."1 Acheson goes on to say that "The plans, military and economic, were too ambitious for the means avallable." 2

So, though disappointed and extremely annoyed, the Shah returned to Iran determined to take steps to make his country merit the financlal assistance she needed. He, more than anyone else, knew that the Americans were right about corruption in his country's govermmental system. In his own words,

The failure of my mission was certainly in part our fault, because Americans realized that we were not yet handling our internal affairs with the necessary firmess. America had been shocked by the collapse of National China . . . and she was determined to aid only those countries which showed a desire to clean house at home. 3

The Shah did not merely talk about reform, but actually initiated serlous steps toward it. The U.S. could be credited with the responsibility of generating the impulse and the will to bring it about. One of the Shah's first acts, as early as January 1950, was to break up his Royal Estates to be sold as small farms to the peasants. In February, because of the insistence of the U.S. that he practice more democracy, the Shah provided for "relatively free" elections. 4 In the same month he spoke publicly urging reform and attacking corruption, pressing the implementation of the seven-year plan and the revision

1 Acheson, Present at the Creation, p. 501. 2 Ibid.

3ohammed Reza Shah Pahlavi, Mission for my Country (New York: McGraw-Hi11, 1961), pp. 88-89.

4Cottam, Nationalism in Iran, p. 261. 
of the constitution to allow him the necessary powers to carry out the proposed reforms. ${ }^{1}$

While the peasants were glad that nuw they could own a piece of land, though sma11, the privileged classes were up in arms. The latter strongly opposed the Shah's efforts because he struck at their jealously guarded privileged position. Their resentment was as strong toward the U.S., for they believed that, had it not been for the U.S., the Shah would never have dared to take such steps. Despite this opposition, however, an anti-corruption conmission was soon set up and anti-corruption laws were passed. The appointment of General Ali Razmara as Prime Minister in June 1950 was regarded by many Iranians as interference by the U.S, in Iranian internal affairs. The reason was the suspicion that Razamara was already briefed by the Americans and the British. Though this was a misimpression, 2 it proved unfortunate for him and may have been the cause for his weakened position in the oil negotiations and for his assassination later. When Dr. Henry I. Grady arrived in Iran in June as the American Ambassador, the reform program was vigorously pushed forward. Iranians began to think that they had done enough to deserve a loan. But despite their hopes and wishes, American assistance toward the seven-year plan was not forthcoming; and although their optimism did not completely vanish, tension began to build up in $\operatorname{Iran}^{3}$ as time went by and the

1Lenczowsk1, Middle East in World Affairs, pp. 203-5.

${ }^{2}$ Cottam, Nationalism in Iran, p. 209.

3Lenczowski, Middle East in World Affairs, p. 202. 
Americans showed no signs of relaxing their position.

At about this time, the Anti-Corruption Commission published its report (August 31, 1950), describing 500 government employees as corrupt and unfit for public office. 1 An uproar in the Maj11s followed attacking the report as too harsh and too drastic. This was followed by a U.S. announcement on October 10, 1950, that a loan of only $\$ 25$ million could be granted to Iran, plus a grant (announced October 19,1950$)$ of $\$ 500$ thousand credit under the Point IV program. ${ }^{2}$ This was a far cry from the $\$ 250$ million loan Iran sought, which had been blankly refused. The reaction on the part of Iranians was 1mmediate. Their bitterness and anger toward the U.S. and their anti-American feelings began to rise. Soon the U.S. 1ost the good feeling she had nurtured for herself in Iran. Her consultants in that country were sent home and their contracts were terminated. In short, there developed a general resentment toward America and Americans in Iran. There were wild outbursts of anger and indignation In the Majlis as deputy after deputy stood to denounce the U.S. attitude as an insult to Iranian pride and dignity. One deputy contended that there was nothing that Iran could gain by posing as pro-American. The Shah himself joined the crescendo of rising indignation. 3

I Ibid., pp. 201-2.

2 Cottam, Nationalism in Iran, p. 211.

${ }^{3}$ Lenczowski, Middle East in World Affairs, p. 204. 
None could have been happier than Russia and the Tudeh party, for Iran quickly moved to sign a trade agreement with the Soviet Union on November 4, 1950.1 Sooi after, pressure to revise the British oll concessions began to build. Fallure to obtain the desperately needed loan focused Iranian eyes on the A.I.O.C. (Anglo-Iranian Oil Company).2 The stage was set for the ensuing oil crisis and for the rlse of Dr. Mossadegh and his National Front. "Such a serlous setback to our hopes," lamented the Shah, "convinced many of our people that the United States had deserted them, and anti-American feeling developed, with a corresponding strengthening of the National Front Pact." 3

III. THE U.S. AND THE OIL CRISIS

Soon after American oil companies and Venezuela reached an agreement to share profits from Venezuelan oil on a fifty-fifty basis, Iran asked the A.I.O.C. to raise her share of the profits. 4 But the failure to obtain an American loan in 1950, lent this request a measure of urgency not existent when it was first made in early 1948. Negotiations were underway between Saudi Arabia and ARAMCO to reach an agreement based on the fifty-fifty profit sharing principle, already in

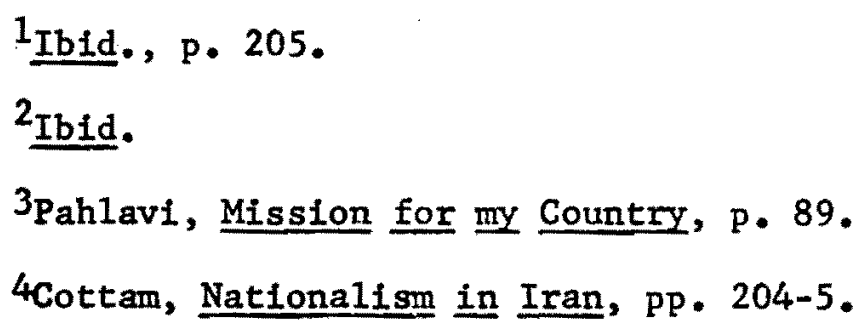


practice in Venezuela. As Prime Minister Razmara repeatedly urged the A.I.O.C. to make concessions before it was too late, the British were hardly aware of the seriousnss of the situation. When they finally woke up in February 1951 to the realities surrounding their Investments in Iran, it was already too late. The British sluggishness and the momentum gained by the Iranian national movement under Mossadegh produced a situation under which the nationalists no longer were satisfied with a fifty-fifty profit sharing arrangement, but demanded complete nationalization of the oil industry. The proposal of November 1950 to the Majlis Oil Conmittee by Dr. Mossadegh to nationalize the ofl industry was taken to the Maj1is. On March 15, 1951, the Majlis voted unanimously to nationalize Iranian oil and, five days later, the decision was confirmed by the Iranian Senate. 1

\section{The Rise of Mossadegh}

The nationalization of the oil industry had taken place amid a tremendous amount of pressure from public opinion. The mood was such that when Razmara, on March 3, 1951, appealed to the $0 i 1$ Commission to consider the question of nationalization on its economic merits, to have experts study the problem realistic $1 \mathrm{y}$ and prudent1y, and declared that he was convinced Iran was not able of exploiting her petroleum resources on her own, ${ }^{2}$ his moderation caused his

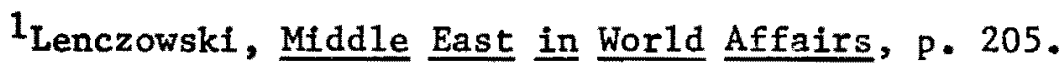

2 John Marlowe, Iran: A Short Political Guide (New York: Praeger, 1963), p. 92; Andre Fontaine, History of the Cold War From the Korean War to the Present (New York: Random House, 1969), p. 146; Cottam, Nationalism in Iran, p. 205. 
assassination four days 1ater on March 7, 1951.1 Before that, in the fall of 1950, national feeling was such that Dr. Mossadegh, the symbol of nationalism and national aspiration, was named Chainman of the $0 i 1$ Commission. 2 When Razmara was assassinated, the last serious block In the way of nationalization was removed. Before the Majlis voted on the issue, Dr. Mossadegh told of a white figure that appeared to him the previous night and exhorted him to "Stand up, Mossadegh, go burst the chains of the Iranian people!"3

Hussein Ala, the new Prime Minister, lasted only a few weeks. 4 Pressure to appoint Dr. Mossadegh as Premier increased tremendously. The Shah reluctantly appointed him on April 28, 1951, after his attempt to appoint Qavam failed. On May 2, 1951, the Shah proclaimed the oil nationalization 1 aw. 5 The Tudeh party suddenly became active and held demonstrations carrying red flags and shouting anti-imperialist slogans. In early May, Tudeh representatives called on Mossadegh and demanded legalization of their party, recognition of Red China, rejection of U.S. arms aid, nationalization of the American-controlled oil fields in Bahrein, and the expulsion of the remnants of the American military mission in Iran. Great Britain invoked the 1933 oil accord and proposed

1Lenczowski, Middle East in World Affairs, p. 205.

2Fontaine, Cold War from Korean War to Present, p. 146.

${ }^{3}$ Inge Morath, From Persia to Iran (iondon: Thames and Hudson, 1960), P. 56.

4Henry F. Grady, "Tension in the Middle East with Special Reference to Iran," Proceedings of the Acadermy of Political Science, XXIV (January, 1952), 119 .

5Lenczowski, Middle East in World Affairs, p. 206. 
arbitration, but Mossadegh refused to comply. The Abadan refinery had to be shut down because British technicians refused to work for the new National Iranian Oil Company. When the International Court of Justice took conservation measures on Britain's request in July 1951, Iran refused to observe them. Britain's protests as to the 11legality of the Iranian action were to no avail. Iran's position was that, as a sovereign nation, it was her right to nationalize her ofl industry, and argued that oil concessions were forced upon her when her government was under British contro1. It was time, therefore, that Iran be freed of British bondage and exploitation. 1

\section{The Stalemate}

Negotiations between Britain and Iran broke down in August. President Truman's attempt at conciliation also failed. On September 10, 1951, Britain cancelled her commercial ties with Iran and Abadan-bound British tankers were ordered to return. On September 25, Mossadegh retaliated by ordering the expulsion within a week of all British personnel at the Abadan refinery and its occupation by Iranian troops. 2 Britain was tempted to use force; her navy and troops were alerted. ${ }^{3}$ But though they arrived in Iranian waters, they never landed. The reason Britain did not act is related by Anthony Eden in his memoirs:

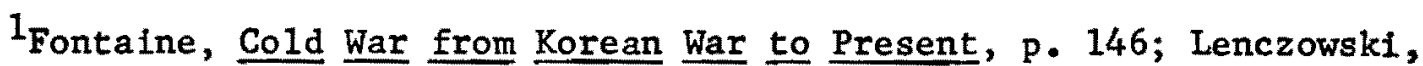
Middle East in World Affairs, pp. 207-8; Sheehan, Iran, pp. 53-56.

2Ibid., pp. 208-10.

3Bahman Nirumand, Iran: The New Imperialism in Action (New York: Morthly Review Press, 1969), p. 50 . 
"The temptation to intervene to reclaim this stolen property must have been strong, but pressure from the United States was vigorous against any such action."1 The United States calculated that interference by Britain could very well force the Soviet Union to invoke the 1921 Soviet-Persian Treaty, ${ }^{2}$ according to which Russia was given the right to occupy the Northern part of the country if and when a third power intervened. There was also the fear on the part of the U.S. government that failure of the nationalists "might bring the Communists to power." 3

Instead of milftary action, Britain intensified her economic pressures on Iran. She ordered an embargo on Iranian oll and set up a virtual economic blockade of Iran. Iran found herself unable to break the embargo and the Iranian economy began to feel the pinch. ${ }^{4}$ British Foreign Secretary Anthony Eden, a Conservative and a disciple of Churchi11, who replaced Ernest Bevin in October 1951, realized the importance of convincing the U.S. to give up her neutrality regarding the ofl crisis. He believed that the policy of coming to terms with Mossadegh at any price "would be a policy of despair." 5 He had no respect for the argument that "the only choice in Iran lay between Mossadegh and Communism."6 But he also realized that it was hard to sell these

1Anthony Eden, Fu11 Circle (Boston: Houghton Mifflin, 1960), pp. 216-17.

2Shwadran, Middle East: 0 i1, pp. 82-84.

3 Fontaine, Cold War from Korean War to Present, p. 174.

4Lenczowski, Middle East in Wor1d Affairs, pp. 210-12.

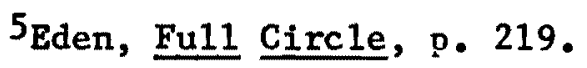

6Ibid. 
Ideas to President Truman, who happened to hold an opposite view. According to Henry Grady, "Mossadegh with the great mass of the people behind him cannot easily be gotten rid of. Nor would it help to do so!"1 President Truman, however, supported Britain in trying to get the International Court of Justice to rule on the compensation to be paid to the A.I.O.C. for its nationalized property. Dr. Mossadegh categorical1y refused and went to New York himself in the fall of 1952, where he skillfully presented his country's case before the U.N. Security Council, then considering Britain's complaint against Iran. Before returning to Iran he visited and had talks with American officials ${ }^{2}$ and personally requested a loan of $\$ 120$ million from the U.S. to meet the emergency situation in Iran. On his way back to Iran he stopped in Cairo, where he was given a tremendous welcome. When he finally arrived in Iran, the near hysterical reception he had showed the immense measure of popular support he still enjoyed. To the welcoming crowds he said, "It is better to be independent and produce only one ton oil a year than to produce thirty-two million tons and be a slave to Britain." 3 The $\$ 120$ million loan re lested by Mossadegh was not granted. Nevertheless, the U.S. continued to seek a solution through conciliation and urged the World Bank to grant Iran an emergency loan of $\$ 23$ million and promised her military aid. Meanwhile, to deal with the problems

${ }^{1}$ Grady, "Tension in .. Iran," p. 560 .

2Nirumand, New Imperialism, p. 56.

3Dwight David Eisenhower, Mandate for Change, 1953-1956: The White House Years (Garden City, N.Y.: Doubleday, 1963), p. 159. 
Iran was facing, Dr. Mossadegh asked and obtained speclal powers. As he strove to gain control of the army, tension began to bulld between him and the Shah. By the zummer of 1952, he had what amounted to almost complete control of the government. On October 16 he broke diplomatic relations with Great Britain. ${ }^{1}$ But as he made the error of attacking the Shah, and as the economic and political difficulties began to mount, Mossadegh's power base began to break up. He lost the support of the army and of the religious elements, such as Mollah Kashani and his followers." According to Rlchard Cottam, "After midsumer 1952 . . many nationalists began drinfting away from the Nationalists." 3 So many of his supporters had been allenated by his failure to settle the oil dispute, by his authoritarianism, and by his capricious manners, that he was forced to abolish the Majlis in early August 1953 and rule by decree. Mossadegh became a virtual dictator and the Shah began his struggle against being completely choked out politically.

In spite of her involvement in the Korean War, the United States government became deeply involved in the Iranian o11 dispute, first trying to be neutral and acting as an arbitrator but later shifting her position to coinclde with that of Britain. The Iranian ofl dispute affected the Korean war effort and the ofl needs of Europe. By the time President Eisenhower took over as President, the U.S. was beginning

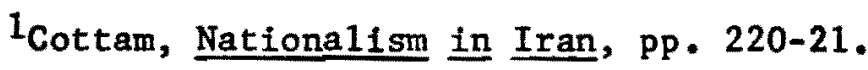

2 Ibid., p. 215.

3I Ibid., p. 211.
} 
to take a second look at nationalization. Such an act could set a precedent which would jeopardize American ofl concessions in oilproducing cointries. Besides, unilateral cancellation of contracts could seriously undermine the basis of international business. Moreover, there was fear that economic distress could endanger Iran's survival and independence as a nation. With Iran weakened, communism could easily bring it into the Soviet orbit and open the whole Middle East to Soviet penetration. 1 But when Anthony Eden visited Eisenhower in the spring of 1953, Eisenhower st111 considered Mossadegh "as the only hope for the West in Iran, 2 and insisted that the U.S. should continue to play her role of mediator to achieve conciliation.

The Iranians felt that the U.S. ought to help them rid their country of British influence; while the British felt that the battle was as much America's as it was theirs; for if lost, America's oil interests would suffer too. The stubborn attitude of Mossadegh and his followers gradually drove the U.S. to a united front with Great Britain. As the U.S. began to apply pressure on Iran, suspicion of her mounted, ${ }^{3}$ and the Tudeh party seized the opportunity to accuse her of imperialism and collaboration with Great Britain. Mossadegh and his policy planners could not understand the behavior of the U.S. since they thought that her fear of communism and her dependence on Iranian oil would cause her to override Britain. They were confident that the U.S. would supply

${ }^{1}$ Lenczowski, Middle East in World Affairs, p. 212.

2Eden, Ful1 Circle, p. 235.

${ }^{3}$ Cottam, Nationalism in Iran, pp. 214-15. 
Iran with large amounts of aid. But Mossadegh should have realized that the U.S. was no longer willing to support him in the methods he chose to handle the delicate situation. However, because she wanted to maintain her relationship with Iran and to prevent a total collapse of her economy, the U.S. gave Iran limited aid in the form of financial transfusions. According to the Shah, Mossadegh "let his negative emotionalism rule out any chance of agreement."1

For the U.S. it was a great dilemma. The British point of view could not be disregarded. The oil interests of both countries were simflar and British friendship was needed, especially in the face of communist threats in Korea. America's interests in Iran were a1so important--Iran must not be allowed to drift behind the "Iron Curtain." At any rate, the British argument made more sense to the United States than the Iranian one, especially after Britain accepted the nationalization 1aw. The U.S. continued her mediation we11 into 1953, but it only served to severely strain relations between her and Iran. Hostility against America became more intense; American military and technical assistance was criticized; and American citizens in Iran were insulted and occasionally physically attacked. 2

The Fall of Mossadegh

Dr. Mossadegh, desperate for funds, tried to draw the attention of President-elect Eisenhower to Iran's problems while still at Columbia University. In his memolrs President Eisenhower says,

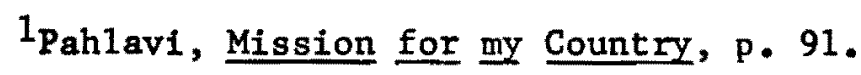
${ }^{2}$ Sheehan, Iran, pp. 56-57. 
even before I was inaugurated . . early in January 1953, while I was still living on the Columbia University Campus, I received a cable from Premier Mossadegh, who by that time was ruling the country by decree. In his cable, three pages 1.ong, he congratulated me on the election results, and then plunged into an extended dissertation on the problems of Iran, which he feared had already been presented to me by those who did not see eye to eye with him on his country's future. 1

Mossadegh wrote,

I dislike taking up with you the problems of my country even before you assume office. I do so partly because of their urgency and partly because $I$ have reason to believe that they have already been presented to you by those who may not share my concern for the future of Iran and its people. 2

Eisenhower sent a prompt reply assuring the Prime Minister that he "had in no way compromised a position of impartiality and that no one had attempted to prejudice me in the matter. I expressed the hope that our own future relationships would be completely free of any suspicion."3

On May 28, 1953, Mossadegh wrote another letter to Eisenhower, described by several writers as a piece of international blackmai1. 4 "There can be serious consequences, from an international viewpoint," the Premier warned, "if this situation is permitted to continue. If prompt and effective aid is not given this country now, and steps that might be taken tomorrow to compensate - . might well be too late." 5 The implication was that the only alternative was communism. Mossadegh

$1_{\text {Eisenhower, Mandate for Change, p. } 160 .}$

2 Ibid.

${ }^{3}$ Ibid., PP. 160-61. be cited.

${ }^{4}$ Cottam, Nationaliss in Iran, p. 216; ors of several that could

${ }^{5}$ Eisenhower, Mandate for Change, p. 161. 
first thought that the loss of Iranian oil would bring concessions from the West. But he was proved wrong since the market was so glutted with Iraqi, Kuwaiti, and Saudi-Arabian oil, plus that of Venezciala, that oil companies operating in those countries were hoping the oil crisis in Iran would not be settled. During the month it took Eisenhower to send a rep1y, Mossadegh realized that President Eisenhower's cooperation was not going to be obtained easily. In desperation, therefore, he allowed the Tudeh party a free hand to play on America's fear of communism. He certainly was not conspiring with the communists, but In his effort to frighten the Americans, ${ }^{1}$ some American officials, Including President Eisenhower, thought he was. But whether the United States was afraid of communism or whether she finally gave up on Mossadegh, she decided to act. Her action, however, was not according to Dr. Mossadegh's expectations. On June 29, 1953, President Eisenhower in his reply to Mossadegh refused to "pour more American money into a country in turmoil in order to bail Mossadegh out of troubles rooted in his refusal to work an agreement with Britain."2 The President wrote,

it would not be fair to the American taxpayers . . . to extend any considerable amount of economic aid to Iran so long as Iran could have access to funds derived from oil and oil products . . . Similarly, many American citizens would be deeply opposed to purchase by the United States government of Iranian oil in the absence of an oil settlement. $3^{8}$

\footnotetext{
${ }^{1}$ Cottam, Nationalism in Iran, pp. 216-17.

2Eisenhower, Mandate for Change, p. 162.

I Ibid.
} 
After deciding to abolish the Majlis, a plebiscite was held on August 2, in which Mossadegh got 99.4 percent of the votes and, according to Eisenhower, "Iran's downhill course toward communist-supported dictatorship was picking up momentum."1

Mossadegh was already defeated. Richard Cottam contends that as opposition ranks swelled against Mossadegh, it included landowners, merchants, members of the court, officers of the army, and clerical leaders, plus splits within his National Front. ${ }^{2}$ But Mossadegh would not give in. Instead he strove to continue his regime without oil revenue and without American aid. He had hoped that the Soviet Union would grant Iran $\$ 20$ million to keep his treasury afloat for two or three more months. In fact, a new Soviet Ambassador arrived in Teheran in early August. But Eisenhower's letter was published and broadcast over the Voice of America. ${ }^{3}$ Iranians realized that the U.S. had given up on Mossadegh and his government. Soon a CIA plan to oust him from power was underway. According to accounts of what followed, supplied by the Shah in his Mission for my Country and by President Eisenhower in his Mandate for Change, 1953-1956, one gets the impression that the move against Mossadegh was a purely spontaneous popular revolt and that once the people knew what the Shah wanted, opinions began to crystallize. Other observers believe, however, that it was not all that simple; that interference by foreign agents $w / 3$ evident and that

I Ibid., p. 163.

${ }^{2}$ Cottam, Nationalism in Iran, pp. 223-25.

3. 
huge sums of money were expended on an intricate operation to bring about Mossadegh's downfall. There is no reason to dispute the fact that the American CIA was instrumental in bringing about the fall of Mossadegh, especially after Allen Dulles confirmed it. Speaking of Iran and Guatemala and the intention of their leaders to turn them Into communist-dominated countries, Allen Dulles records,

When this purpose became clear, support from outside was given to loyal anti-Cormunist elements in the respective countries, in the one case, to the Shah's supporters; in the other to a group of Guatemalan patriots. In each case the danger was successfully met. 1

Miles Copeland, who calls himself an American "cripto-diplomat" and operated in the Middle East for a long time, tel1s how in August 1953, and in Operation Ajax, his colleague Kirmit Roosevelt "almost singlehandedly called pro-Shah forces on to the streets of Teheran and supervised their riots so as to oust Mossadegh and restore the Shah, who had fled to Rome. ${ }^{2}$ Andrew Tully contends, "It is senseless . . to say that the Iranians overthrew Mossadegh all by themselves. It was an American operation from beginning to end." 3

The operation by the CIA involved, among others, its own chief, Allen Dulles, Ambassador Henerson, General Schwartzkopf (a former director of the American police mission to Iran), "whose membership

$1_{\text {Allen Dulles, The Craft }}$ of Inte11.igence (New York: Harper and Row, 1963), P. 224.

2Miles Copeland, The Game of Nations: The Amorality of Power Politics (London: Weidenfeld and Nicolson, 1969), p. 51. p. 96.

${ }^{3}$ Andrew Tully, CIA: The Inside Story (New York: Morrow, 1962), 
in the famed Central Intelligence Agency was known to everyone," 1 and Princess Ashraf as they met in Switzerland for a joint "vacation." On August 13, the Shah dismissed Mossadegh anc appointed General Zahedi Premier. When the note reached Mossadegh on the $15 \mathrm{th}$, he had the officer sent to deliver it arrested and thrown in jail. The revolt was announced crushed. The Shah, fearing for his life, took his queen and fled the country to Rome through Baghdad. But, according to Andrew Tu11y,

Shwartzkopf . . held his ground on the Iranian stage. He took over as unofficial paymaster for the Mossadegh-Must-Go clique. Certain Iranians started to get rich, and the word later was that in a period of a few days Shwartzkopf supervised the careful spending of more than ten million of CIA's dollars. Mossadegh suddenly lost a great many supporters. 2

Fred Cook observes that the "CIA showed a tendency, if not to brag, at least to chuckle in public about this wily and triumphant coup; but the aftermath has furnished no cause for unalloyed rejoicing."3 On August 19, a pro-Shah demonstration followed by army units led by Zahedi overthrew Mossadegh, who was captured in the same day clad in his famous pajamas and thrown in jail.4 General Zahedi took over

1Fontaine, Cold War from Korean War to Present, p. 151.

2Tu11y, CIA, p. 95.

3Fred J. Cook, "The CIA," The Nation, Special Issue (June 24, 1961), 532; for further details on the August 19 coup, see also, Richard and Gladys Harkness, "The Mysterious Doings of the CIA," Saturday Evening Post (November 6, 1954), 34ff.

${ }^{4}$ Accounts differ. According to one account, he turned himself in to the authorities the following day. 
as Premier and the Shah returned. The coup was carefully staged to appear as though it was an Iranian uprising in favor of the Shah brought about spontaneously. The:e is no doubt that there were many who opposed Mossadegh, but there is no doubt either that they got most of the encouragement from the CIA, and this fact was not hidden from educated Iranians. The impact of this action was far-reaching as it helped bring a complete change in the political climate in Iran. The first act of the new government was to outlaw the Tudeh party and hunt down its members. National Front members went underground as they were barred from active political life and from the parliament. As a result, the U.S. was blamed by the Nationalists for their misfortune. To them, both the Shah and Zahedi were American puppets, who brought Iran under forefgn domination. According to Don Peretz,

Although the Shah has . . attempted to make himself the symbol of unity, a strong feeling has not been revived since the downfall of Mossadegh. Since then, Iran has again been torn by the divisive elements that have so often prevented it from becoming a unified nation in the past. 1

\section{THE AFTERMATH}

The coup against Mossadegh was an American gamble, but a winning one. The Shah was clearly favored by the U.S. As a result his position and influence were tremendously strengthened. He gained absolute control over the government, was able to crush all opposition, and to consistently follow a pro-American policy. The U.S. moved quickly to

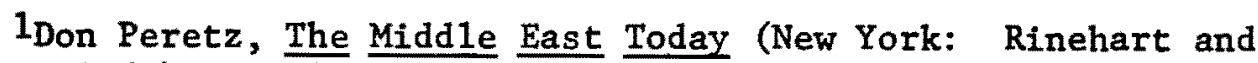
Winston, 1963), pp. 429-30. 
find a solution to the ofl problem. In the meantime, Iran desperately needed funds. So the U.S. supplied her with a $\$ 45$ million loan until oil operations could be resumed. 1

The author of the Venezuelan petroleum 1aw, Herbert Hoover, Jr., was dispatched to Teheran. Both General Zahedi and the Shah were eager to reach a solution so the country could stand on its feet again. Due to the situation in Iran, oil nationalization could not be undone-a fact that Hoover could not ignore. While still in Teheran, Hoover struck upon the Idea of an oil consortium. In London, his idea met with opposition at first, but after several exchanges in both London and Teheran, it was tentatively agreed upon. In December 1953, major oll companies met in London to discuss its feasibility. A.I.O.C. demanded a controlling share, but the U.S. objected. What the U.S. wanted and got was that each of Britain and the U.S. would hold $40 \%$ of the shares in the consortium, and the remaining $20 \%$ of the shares would be divided between France and Holland. The U.S. share was divided equally among five different U.S. companies: Standard Oil of Calffornia, Standard 0il of New Jersey, Socony-Mobile, The Texas Company, and Gulf Oil. In March 1954, partlcif $=1$ ing companies began talks with the Iranian government and the A.I.O.C. In Teheran. By the end of October, the agreement was ratified by the Majlis and approved by the Shah. In November normal ofl operations were resumed.

Since 1953 the U.S. has supplied Iran with massive amounts of ald, making her one of the major recipients of American aid. Approximately

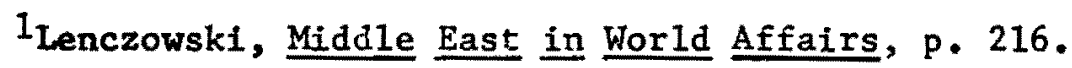


half of the aid was toward building Iran's army. Immediately following the overthrow of Mossadegh in August, the U.S. government, according to Andrew Tully, whose figures come from the 1957 report of the Committee on Governmental Operations of the House of Representatives, "began to feed mutual security funds into Iran at an average rate of five million dollars a month, and kept this up for three years to make up deficits in Iran's budget."1 Incidenta11y, the House Committee revealed that American aid in Iran was so 1oosely administered and so poorly handled that it was "impossible--with any accuracy--to tell what became of the funds." 2 The situation has, no doubt, improved since then. Through financial aid, the U.S. has become the principal supporter of the Iranian army and the principal source of development funds, not including revenue from oil. Without American assistance, the Iranian economy would have collapsed. As a result the U.S., through this aid and through her participation in the 1.0.C., acquired a firm hold on the Iranian economy. Naturally this influence was resented by many Iranians, and U.S. aid was considered an obligation after being instrumental in bringing about the fall of Mossadegh. Many also thought that assistance was the necessary price for Iran's continued support of the Western alliance system.

As the chief source of equipment, advice, and funds for Iran's army, the U.S. concluded that the army was the mainstay of the Shah's regime. The Shah was to fulfill the hope of the U.S. in fostering

\footnotetext{
1Tu11y, CIA, p. 97.

${ }^{2}$ Quoted in Ibid.
} 
stability as against chaos and a communist take-over. With the army continuing to be loyal to the Shah, its improvement and strength would serve to keep the Shah in pcwer and naintain internal order, not to protect or defend Iran against Russia. In the course of an investigation of the military aid program to Iran, Senator Hubert Humphrey reported that the Chief of Iran's army, then, said that the Iranian "Army was in good shape, thanks to U.S. aid--it was now capable of coping with the civilian population."1 U.S. interest accounts for the $\$ 530,100,000^{2}$ the U.S. spent on Iran's army between 1945 and 1961 , and for its American training and organization. The economy and the Crown, therefore, became dependent on the U.S. for support and assistance. Thus by her continued support to the Shah, the United States made al1 Irantans who were anti-Shah also anti-U.S. In exchange, the Shah's regime followed a consistently pro-Western policy, joined the Baghdad Pact; and when this was dissolved following the 1958 Revolution in Iraq, Iran joined the Central Treaty Organization.

On the economic leve1, the Shah has apparent1y succeeded beyond any expectations. By 1900, "economic development went forward by leaps and bounds,"3 according to T.C. Young, U.S. loans amounted to $\$ 200$ million in economic aid and to $\$ 850$ million in military aid between

IHubert Humphrey, quoted in David Horowitz, The Free World Colossus (New York: Hi11 and Wang, 1965), p. 190.

${ }^{2}$ Sheehan, Iran, P. 51.

${ }^{3} \mathrm{~T}$. Cuyler Young, "Iran in Continuing Crisis," Foreign Affairs, XL (January, 1962), 280. 
1950 and 1960.1 The successes gained under the Shah cause one to doubt whether the Nationalists could have produced better results in the "guz.rdianship and guidance of the nation."2

1 Ibid.

2 Ibid., p. 287. 
CHAPTER II

THE CREATION OF THE STATE OF ISRAET

Zionism originated in Russia. It was first preached by Leon Pinsker, a Russian Jew, in 1882. The most effective polftical leader of Zionism, however, was Theodore Herzl, an Austrian Jew, who wrote The Jewish State. This book and Herz1's other efforts resulted in the creation of the World Zlonist Organization. Herzl's initial b1d co obtain Ottoman approval of the Zionist pian to establish a Jewish Home in Palestine did not meet with much success. In 1903, England offered an African protectorate for that purpose. Th1s offer was refused by the Russian Zionist majority despite the fact that Herz 1 was in favor of 1t. It was in Palestine that they wanted their Jerish Home established.

\section{ZIONISM AND THE POWERS}

Russian pogroms in the late nineteenth century caused many Jaws to Immigrate to Western Europe and the United Stateg. As a result, Zionism spread to those areas, which eventually became the main centers of Zionist activity. 1 Dr. Chaim Weizmann and Nahum Sokolow solfc1ted the ald of British statesmen as sarly as 1906, and their mise1on eventually resulted in the issuance of the Balfour Declaration of

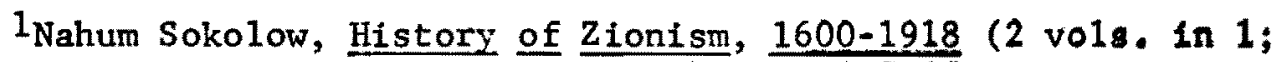
New York: KTAV Publishing House, 1969), pP. 217-27. 
1917 by Arthur Balfour, Britain's Foreign Secretary. 1 The United States extended her support for this Declaration a short time later. ${ }^{2}$ France and Italy followed with vague gestures of support. 3 The Al11es were not only interested in Zionism, but also gave support to its movement in order to secure the help of Jewish members in the Rerensky government of 1917 in encouraging the Russians to stay in the War, to outbid the Germans in soliciting the support of world Jewry, and to strengthen Britain's position in the Middle East through a Jewish-dominated Palestine.

To the Arabs, Britain made the promise of complete independence under a unified Arab nation (including Palestine) as a reward for joining the war on the side of Britain and her allies. But on May 16, 1916, Britain and France signed the secret Sykes-Picot Agreement, dividing many Arab territories into zones of influence, British-andFrench-administered areas, and provided for the internationalization of Palestine. When the Russian revolutionary government made known the terms of the Sykes-Picot Agreement in December 1917, Britain reaffirmed her promises to the Arabs and declared that the treaty was not formal. The Arabs were appeased, and Britain continued to enjoy Arab confidence and support. When Arab fears began to rise

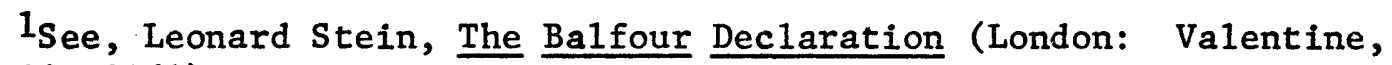
Mitche11, 1961).

${ }^{2}$ Chaim Weizmann, Trial and Error (New York: Harper, 1949), p. 211. 3 Ibid., Pp. 212-13; Stein, Balfour Declaration, pp. 465-71, 520-32, 587-97. 
again, Britain and France issued a joint statement assuring the Arabs "complete and final liberation."1 These promises and President Wilson's "Fourteen Polnts" gave the necessary assurance the Arabs needed in support of the principle of national self-determination.

In 1922, Palestine became a separate political entity when Britain received it as a mandated territory. The terms of the mandate, wich incorporated the Balfour Declaration, were signed with the League of Nations. Under the mandate, the Jews were allowed to set up the Jewish Agency, and Hebrew became an official language in Palestine 1ike Arabic and English. The Arabs considered this arrangement unjust, undemocratic, and contrary to all the promises made to them. The first British Commissioner's efforts to organize an advisory council met with Arab resistance and ultimately failed. The $\mathrm{zionist}$ aim was to retain the mandate until large-scale immigration placed the Jews in the majority and then to press for a Jewish state. Unrestricted immigration, therefore, was vital to the Jews, but objectionable to the Arabs. That is why it became the basic source of friction. 2

By 1936, the Zionists had thoroughly cultivated the Western press, public, statesmen, and had organized Zionist cells throughout the world to gain support for their cause. After 1933, Nazi persecution brought an up-swing in Jewish immigration to Palestine. When the

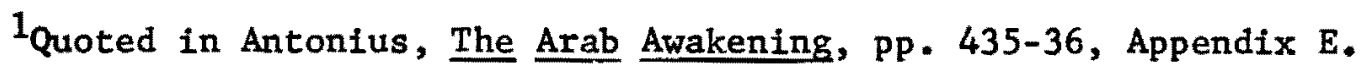

${ }^{2}$ Fred John Khouri, The Arab-Israeli Dilemma (Syracuse, N.Y.: Syracuse University Press, 1968), pp. 17-24. 
Palertinian Arabs revolted in 1936-37, Britain arrested their leaders or forced them to flee. Several Royal commissions reported that the basic causes for unrest were Arat desire for independence and their fear of Jewish objectives in Palestine. Britain came to the realization that she had trapped herself with conflicting promises to both Jews and Arabs and the way out was becoming more difficult every day.

Perhaps the most important British effort to settle the Palestinian problem was the Peel Commission of 1937, which drew up plans for partitioning Palestine. The Jews agreed to those plans provided they got a large area. The Arabs strongly objected and stepped up their acts of violence against the British mandate government. When it was concluded that partition was not workable, Britain called the two Palestinian communities and the Arab States for a conference, which was held in London during March 1939. This conference, like all previous British efforts to settle the problem, failed.

The British government, realizing once more her need for Arab support, issued a white paper that favored the Arabs. Italy and Germany were at work arousing Arab feelings against Britain. The 1939 White Paper, by restricting Jewish imigration to 75 thousand over a 5-year period and prohibiting land sales to Jews in certain areas, quieted the Arabs and secured their cooperation. Quite naturally, the Jews opposed the 1939 White Paper and accused Britain of a breach of contract. When war broke out, however, both Jews and Arabs joined the British forces. The Jewish Agency, realizing that eventually the Zionists would have to fight either the Arabs or the British (or both) to set up their state, encouraged Jewish youth to join the British 
armed forces. Some 43,000 Palestinian Jews were enlisted. Britain set up a separate Jewish Brigade, which eventually became the backbone of Haganah, the principal Jewish fighting force in Palestine. In contrast, only about 8,000 Palestinian Arabs joined the British forces. Illegal Jewish Immigration to Palestine was stepped up along with arms smuggling and stealing of ammunition that belonged to the British forces.

When Churchill came to power, the Zionist position was boosted because he was a known supporter of their objectives. In May 1942, the Zlonist Biltmore Program called for a Jewish state officially for the first time. Until then, the Zionists had been calling for a Jewish Home. In November 1944, Weizmann was privately informed by Churchill of a British Cabinet decision to ultimately grant the Jews a state in Palestine. The Arabs, on the other hand, were continuing to receive assurances that Britain was standing by the 1939 White Paper--their support was needed while the war was still on!

In the United States, the government was sympathetic toward the Jewish cause. Its sympathy, however, was mainly due to humanitarian considerations. Since early twentieth century, America had conducted gustained negotiations with the Ottoman Empire with regard to the Jews. Zlonist influence was not felt in the United States, however, until World War I. Although President Wilson was cautious in dealing with American Zionists and despite warnings by members of his own government against aking public statements in favor of the Balfour Declaration, the Zionists finally succeeded in convincing him to write Rabbi Stephen Wise on August 31, 1918, 
I have watched with deep and sincere interest the reconstructive work which the Weizmann Commission has done in Palestine at the instance of the British Government, and I welcome an opportunity to express the satisfaction I have felt in the progress of the Zionist Movement in the Unit-d States and in the Allied countries since the declaration of Mr. Balfour on behalf of the British Government, of Great Britain's approval of the establishment in Palestine of a national home for the Jewish people, and his promise that the British Government would use its best endeavors to facilitate the achievement of that objective, with the understanding that nothing would be done to prejudice the civil and religious rights of non-Jewish people in Palestine or the rights and political status enjoyed by Jews in other countries. 1

On September 21, 1922, the U.S. Congress passed a joint resolution endorsing the provisions of the Balfour Declaration. On December 3, 1924, the United States recognized the British mandate over Palestine when the Anglo-American Mandate Treaty was signed. 2 On the whole, however, the U.S. government remained quite indifferent to the Zionist character of the Palestine mandate during the 1920's and the early 1930 's, since American Zionism was not yet a serious force to be reckoned with. But in 1937, the State Department issued a statement that came shortly before the Peel Commission submitted its report. The statement said,

As is we11 known, the American people have for many years taken a close interest in the development of the Jewish National Home in Palestine. Beginning with President Wilson each succeeding president has on one or more occasions expressed his own interest in the idea of a National Home and his pleasure in the progress made in its establishment. 3

1Quoted in Frank E. Manuel, The Realities of American-Palestine Relations (Washington, D.C.: Public Affairs Press, 1949), p. 176.

${ }^{2}$ Corde11 Hu11, The Memoirs of Corde11 Hu11 (2 vols.; New York: Macmillan, 1948), II, 1528 .

3. 
On July 6, 1937, the United States inquired of Britain whether she would be consulted on matters pertaining to Palestine and the Peel Conzission partition proposa1s. ${ }^{1}$ The 1939 British White Paper was recelved with a good deal of dismay in Washington. Soon after, the American Palestine Committee was organized. In ear1y 1944, resolutlons were introduced in the Senate and in the House of Representatives In favor of Jewish objectives in Palestine. However, Secretary of State Corde11 Hu11 says,

At the State Department we felt that the passage of these resolutions, although not binding on the executive, might preclpitate conflict in Palestine and other parts of the Arab world endangering American troops and requiring the diversion of forces from European and other combat areas. It might prejudice or shatter pending negotiations with Ibn Saud, for the construction of a pipeline across Saudi Arabia, which our military leaders felt was of utmost importance to our security. ${ }^{2}$

But by then the American Jewish community had become the most influential among the Jews of the world. The American Zionist Emergency Counc11 established a network of branches covering all of the United States. Through an extremely efficient and effective propaganda machine, the American Jews effectively won the support of ordinary Amertcan citizens as well as American officials. As a result, proZlonist resolutions were passed in the majority of state legislatures, and both American politica1 parties came under increasing Zionist pressure as the 1944 Presidential elections drew near.

1Manue1, Realities If American-Palestine Relations, pp. 305-6. 2Hu11, Memoirs, II, 1534-35. 
II. TRUMAN SUCCEEDS ROOSEVELT

Both political parties and their candidates, Franklin D. Roosevelt and Thomas E. Dewey, strongly backed the Zionist program In the Presidential election campaign of 1944. The Jewish vote could not be ignored, and each party tried to outbid the other for it. 1 Shortly after the elections, however, President Roosevelt met with King Ibn Saud, 2 and told Secretary of State Edward Stettinius, while st111 in Egyptian waters, that as a result of his conversation with Ibn Saud, "he must have a conference with congressional leaders and re-examine our entire policy on Palestine."3 In a letter, one week before his death, he promised Ibn Saud that "no decision will be taken with respect to $/ \bar{P}$ alestine $\bar{I}$. . without full consultation with both Arabs and Jews." He closed his letter by further assuring the King that he "would take no action . . which might prove hostile to the Arab people."4 Little did he or Ibn Saud know that death was to deny him the chance to prove how earnest he was. Roosevelt's death must have been very disappointing to Ibn Saud since he had great faith in his personal diplomacy, his principle of national self-determination,

$1_{\text {New }}$ York Times, October 12, 1944; Bradford Westerfie1d, Foreign Policy and Party Politics (New Haven: Yale University Press, 1955), p. 166 ; U.S., Department of State, Foreign Relations of the United States, Diplomatic Papers: 1944 ( 7 vols.; Washington, D.C.: Government Printing Office, 1967), V, 605n, 606n, 616-17.

${ }^{2}$ Foreign Relations ...: 1945 (9 vols.; Washington, D.C.: Gc emment Printing Office, 1967-69), VIII, 2-3, 7-9, 680-82, 701-2, $70 ;-6$.

${ }^{3}$ Edward Rei11y Stettinius, Jr., Rooseve1t and the Russians (Garden City, N.Y.: Doubleday, 1949), p. 289.

4Ibid., p. 290; Foreign Relations...: 1945, VIII, 698. 
hls open-door policy, and deeply appreclated his opinion of Britain as an imperialistic power, who needed to learn to respect other people's sovereignty. 1

Upon assuming his responsibilities as President of the United States, Harry S. Truman received from the Secretary of State Edward Stettinius, 2 -from Acting Secretary of State Joseph Grew, ${ }^{3}$ from his War Department, 4 from State Department Representatives in the Middle East, ${ }^{5}$ chief of whom was Loy Henderson, and from Arab leaders, 6 counsel to be cautious in regard to the question of Palestine, warnings of Soviet intentions in the area, and reminders of President Roosevelt's promise to the Arabs. Aware of the strategic and economic Importance of the area, both the State and War Departments advised that American interests could be safeguarded only by maintaining Arab goodwil1 and friendship. The War Department further warned that a Jewish state could be established in Palestine only by force of arms. President Truman, therefore, formally assured the Arab leaders that he would abide by the promises made to them by his predecessor. 7

$1_{\text {Ibid., 7-8. }}$

${ }^{2}$ Ibid., 704-5; Harry S. Truman, Memoirs (2 vols.; Garden City, N.Y.: Doubleday, 1955-56), I, 68-69.

${ }^{3}$ Foreign Relations...: 1945, VIII, 705.

${ }^{4}$ Ibid., 742.

$5_{\text {Ibid., }} 679-710$.

6 Ibid.

7 Ibid., 707, 708-9; Truman, Memoirs, II, 135. 
Commenting on this in his Memoirs, Truman says, "To assure the Arabs that they would be consulted was by no means inconsistent with my general sympathetic attitude toward Jewish aspirations."1

Truman claims that he had familiarized himself with the question of Palestine and the position of both the Arabs and Britain. 2 And though he appèared, at first, to have heeded the advice of his state Department, he admits that he "was skeptical . . about some of the views and attitudes assumed by the 'striped-pants boys' in the state Department. It seemed to me that they did not care what happened to the thousands of displaced persons who were involved." 3 When he met Rabbl Wise, therefore, it was his "feeling that it would be possible for us to watch out for the long-range interests of our country while at the same time helping these unfortunate victims of persecution to find a home. And before Rabbi Wise left, I believe I made this clear to him. 14

In July 1945, Truman met with Churchill at Potsdam and discussed the situation in the Middle East with him. ${ }^{5}$ By the end of the War in Europe, the brutality of the slaughter of the Jews was revealed and Zionist objectives gained greater sympathy and support. World Jewry

$1_{\text {Ibid. }}$.

2Ibid., I, 69.

$3_{\text {Ibid. }}$

4 Ibid.

${ }^{5}$ Ibid., II, 136; Foreign Relations... : The Conference of Ber1ln, 1945 ( 2 vols.; Washington, D.C.: Government Printing of fice, 1960), I, 979; II, 314-18. 
applied intensive pressure for open immigration and the establishment of a Jewish state in Palestine. Zionist propaganda had so effectively influenced American public opinical that the Palestine question became a burning issue in American domestic politics. ${ }^{1}$ Truman was so Influenced by Jewish political pressure and his sympathy (so he says) for the Nazi victims that he disregarded the advice of his own advisers and experts and the official American promises to the Arabs. He wrote to Churchi11 on July 24, 1945, requesting that restrictions on immigration to Palestine be lifted, ${ }^{2}$ and in a press conference, he answered, "we want to let as many Jews into Palestine as it is possible."3 Truman's pro-Zionist policy became more pronounced in time. However, the cooperation he expected from Churchill was not forthcoming. Before Churchill could reply, Clement Attlee became Prime Minister and Ernest Bevin Foreign Secretary--the Labor Party took over the reins of power following its victory in the July elections. Zionist hopes rose because the Labor Party had consistently supported the Zionist cause. 4 Upon assuming full responsibility for its poilcies, however, the Labor Party found that it could not deal with the Palestine problem without considering Britain's other obligations. Unlike

${ }^{1}$ U.S., Congress, 79th Congress, 1st Session, June 11-October 11, 1945. Congressional Record, vo1. 91, part 12, 3756, 3767, Appendix; Ibid., October 15-December 21, 1945, vo1. 91, part 13, 4482, Appendix; see also volumes of 1943-47. II, $135-36,148$.

2Foreign Relations...: 1945, VIII, 716-17; Truman, Memoirs, ${ }^{3}$ Ibid., 136; Foreign Relations...: 1945, VIII, 722. ${ }^{4}$ Ibid., 796; Ibid., Berlin, II, 1403. 
Truman, both Attlee and Bevin heeded the advice of their officials In the Colonial and Foreign Offices, who were recommending a pro-Arab poifcy to prevent Russian entry into the area and to maintain British influence there. Palestine was to be the new British military base since the one in Egypt was to be abandoned due to Egyptian nationalist demands. ${ }^{1}$ Bësides, a special committee, set up by the Labor government to study the Palestine problem, concluded that without active American military and financial support Britain could not hope to carry out a pro-Zionist program. ${ }^{2}$

Therefore, Attlee's reply on July 31 to Truman's letter in regard to inmigration was not encouraging. ${ }^{3}$ The British Colonial office, in its turn, reaffirmed that no more than 1,500 permits per month would be granted for immigration into Palestine. 4 This stand was fixm and American and Zionist pressures were resisted. Truman, however, persisted and the Zionists accused the British Labor government of a breach of promise. 5 The British government affirmed that, in the face of its obligations in the Arab world, the Jews could not be crowded into the small country of Palestine. And should this take place,

${ }^{1}$ Clement Richard Attlee, As It Happened (London: W. Heinemann, 1945), pp. 244-45; Richard Crossman, "The Role Britain Hopes to P1ay . . . " Commentary (New York), V (June, 1948), 495; Elizabeth Monroe, "Mr. Bevin's 'Arab Policy'," in St. Antony's Papers, no. 11, Middle Eastem Affairs, no. 2; edited by Albert Hourani (London: Chatto \& Windus, 1961), pp. 9-48.

Ibid., p. 29. 719.

${ }^{3}$ Truman, Memoirs, II, 136; Foreign Relations... : 1945, VIII,

4Ibid., 719-20; Weizmann, Trial and Error, pp. 439-40.

5Foreign Relations...: 1945, VIII, 819-20, 759. 
the Arabs were likely to resist by force of arms with Soviet support. This would require American military and financial assistance since Great Britain could not carry the burden alone. 1 Truman, however, could not commit the U.S. to provide such support because he was under pressure from the American Congress and public to demobilize the armed forces and to avoid military commitments. ${ }^{2}$ British officials were annoyed when Truman continued insisting that Britain adopt American policies without Americans assuming any responsibility for implementing them. ${ }^{3}$ The following is Attlee's corment on this same situation several years later: "The Americans thought we should Introduce a hundred thousand Jews into Palestine right away without the slightest consideration for the effect on the Arabs. They had no obligation there. We had." 4

\section{ANGLO-AMERICAN EFFORTS}

In his effort to make the United States share in the burden, Attlee proposed on October 19, 1945, the formation of an Anglo-American Committee of Inquiry. 5 Truman, wishing perhaps to exclude the possibility

1 Ibid., 771-76; Francis Williams, Twilight of Empire: Memoirs ef Prime Minister Clement Attlee, As Set Down By Francis Williams (New York: Barnes, 1962), p. 181; Monroe, "Mr. Bevin's 'Arab Policy"," pp. 27-38; Truman, Memoirs, II, 136-37.

2Ibid., 345; Congressional Record, vol. 91, part 13, 1945, 5666, 5677, Appendix.

3Francis Williams, Ernest Bevin: Portrait of a Great Englishman (London: Hutchinson, 1952), p. 260 .

${ }^{4}$ Williams, Twilight of Empire, p. 181. 141.

5Acheson, Present at the Creation, p. 171; Truman, Memoirs, II, 
of Jewish immigration into the United States, suggested that the inquiries be focused on Palestine. 1 On December 19, 1945, and several months before this Committee released its report, the American Congress pasged a resolution enjoining the American government to secure "free entry of Jews into Palestine so that they may have a chance to proceed to erect a Jewish Home." 2

When the Committee of Inquiry submitted its report on April 20, 1946, they warned that Palestine could not absorb all the Jews who wanted to go there. Therefore, the U.S. and other countries should open their doors to them. It was recommended, however, that 100,000 Jews be permitted to go to Palestine in 1946. Some other recommendations were that since Palestine was holy not only to the Jews but to two other religions, a democratic government with equal representation ought to be set up, that it should become a U.N. trust area, and that further inmigration be based on the agreement between the two communities. ${ }^{3}$ President Truman immediately urged that 100,000 Jews be permitted to go to Palestine without delay. 4 $829-41$.

1 Ibid., 142; Foreign Relations...: 1945, VIII, 775-801,

Ibid., $841-42$.

3U.S., Department of State, Bulletin, XIV (May 12, 1946), 783-84; Documents on American Foreign Relations, July 1, 1945-December 31, 1946, vol. VIII (Princeton, N.J.: Published for the World Peace Foundation by Princeton University Press, 1948), 908-14; Great Britain, Parliament, Papers by Command, Cmd. 6808, The Anglo-American Committee, Final Report, 1946 (London: Her Majesty's Stationery Office, 1946).

4 Documents on American Foreign Relations (Princeton, 1948), VIII, 908-14; Acheson, Present at the Creation, p. 172; Department of State Bulletin (May 12, 1946), p. $\overline{783}$. 
Quite naturally, the British officials were terribly upset over the fact that Truman chose one recomnendation of the report and featured it. At this time Britain was negotiating treaties with Transjurdan and Egypt, and the Arabs were criticizing her for her weakness in dealing with the Zionists. 1 The British government demanded that the report should be considered "as a whole with all its implications." And to this Attlee added that large-scale immigration into Palestine could not be permitted until the Zionists disbanded their underground armed forces and ended terrorism. ${ }^{2}$

The Zionist reaction was increased terrorism in Palestine. ${ }^{3}$ When Britain's mandatory goverment began to make arrests and to take firm measures against the Jewish Agency, the American Zionists and their supporters threatened to work for congressional rejection of the badly needed American 1oan to Britain. Disciplinary action against the Palestine Jews had, therefore, to be suspended. 4 On May 27 and 28 , four Arab States met and issued a statement from Egypt warning both Britain and the United States that, "A1though the Arabs wanted their friendship, that friendship would depend on whether the two democracies would or would not transgress upon the rights of the Palestine Arabs." 5

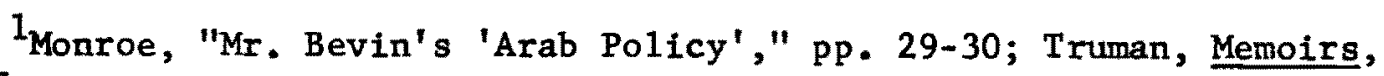
II, 147.

2Ibfd., 149-50; Acheson, Present at the Creation, pp. 172-73.

3ruman, Memoirs, II, 150 .

${ }^{4}$ James Forrestal, The Forrestal Dlaries, edited by Walter Millis (New York: Viking Press, 1951), p. 180.

5idd1e East Opinion, I (June 10, 1946), 16-17. 
This statement was followed by similar ones in an effort to remind the

two governments that the Palestinian Arabs should be allowed their right for self-determination and independence.

The Soviet Union, at this point, took advantage of the situation to win favor and further her interests. Zionism was attacked in Sovlet newspapers as an agent of British Imperlalism and the Anglo-American Committee was criticized for by-passing the Arab States and the United Nations, 1 Such an attack ought to have brought the U.S. and Britain closer together, but it did not. In the face of Russian threats in Turkey, Iran, North Africa, and Europe, Anglo-American accord was being threatened mainly because of the Palestine problem. Arab diplomats called on Acheson and Henderson; they were assured once more that the U.S. government would take no action on Palestine without consulting both Arabs and Jews. 2 But it was obvious that American policy was not being faithful to these promises. Attlee's description of this tug-of-war between those involved is very revealing. He says,

The President went completely against the advice of his own State Department and his own military people. The State Department would tell us one thing and then the President would come out with the exact opposite. The State Department's view was very close to ours, they had to think internationally. 3

In June 1946, Bevin complained that Truman was pressing for immigration into Palestine because he did not want the Jews in the United States. In Bevin's view, Truman's persistence was dictated by

IJacob Coleman Hurewitz, The Struggle for Palestine (New York: Norton, 1950), pp. 246-47; Khouri, Arab-Israe1i Dilemma, pp. 35-36.

2 Acheson, Present at the Creation, p. 173.

3wi11ians, Twiligit of Empire, p. 181. 
domestic politics and because of Jewish contributions to the Democratic Party's purse. 1 Therefore, to avoid further deterioration in relations, Truman and Attlee agreed to review the problem. The Morrison Grady Commission was formed and submitted its report on July 10, 1946. This Commission called for a federal state to consist of a small Jewish proviñce, a large Arab province, and for controlled immigration by a central government, whose executives were to be appointed by the British government. ${ }^{2}$ Both Jews and Arabs rejected the plan and, on August 12 , Truman rejected it too. ${ }^{3}$

In the congressional election campaign of 1946, again both parties supported the Zionist program and, on October 4, President Truman publicly called for immediate admittance of Jews in substantial numbers into Palestine without walting for a solution. ${ }^{4}$ At about the same time, the British government was trying through conferences with Arabs and Jews to find some kind of a solution. When these efforts failed, Bevin alleged that they were undermined by the President's campaign speeches. 5 Bevin's statement annoyed Truman. In his Memoirs he says that the immigration issue "had been the cornerstone of our Palestine policy since my first letter to Attlee August, 1945."6

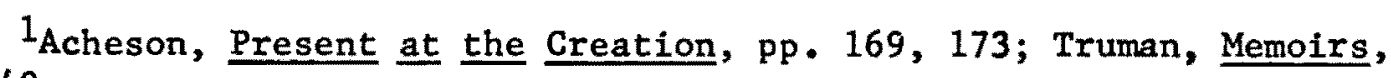
II, 149 .

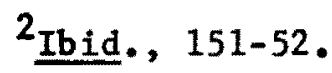

3 Ibid., 152.

4 New York Times, October 5, 1946.

${ }^{5}$ Truman, Memoirs, II, 153-54.

6Ibid., 154. 
The President's position naturaliy weakened the position of the moderate $\mathrm{Z}$ ionists while it encouraged the extremists to hold fast to their maximum demands and to refuse to make any significant concessions. This was evident in the resolution of the 22 nd $\mathrm{Z}$ ionist Congress, held in December 1946, which consented to nothing less than a Jewish state or a favorable partition plan. 1 This situation led to the stiffening of the Arab position too. 2

Following the failure of the Anglo-Jewish-Arab and Anglo-American efforts, Britain submitted her own plan. When this too was rejected by both Jews and Arabs, Britain requested formally on Apri1 2, 1947, that the United Nations General Assembly call a special session to deal with the problem. ${ }^{3}$ Britain apparently had found out that the costs of the mandate outweighed the advantages. The Arabs and Jews were alienated. Besides, the Jews had made Palestine no longer suitable as a British military base. 4

\section{THE PROBLEM BEFORE THE UNITED NATIONS}

When the United Nations General Assembly met in Apri1 1947, a11 went we11, except for Russian insistence that the British mandate be

1Harry Sacher, Israe1: The Establishment of a State (London: Weidenfeld \& Nicolson, 1952), p. 71 .

${ }^{2}$ Hurewitz, Struggle, p. 265; Arab News Bulletin (London, November 18,1946$), \mathrm{p} .2$.

${ }^{3}$ United Nations, Yearbook, 1946-47 (Lake Success, N.Y.: United Nations, Department of Pub1ic Information, 1947), p. 227.

${ }^{4}$ Ibid., p. 281; Crossman, "The Role Britain Hopes to Play," pp. 496-97; Monroe, "Mr. Bevin's 'Arab Policy'," pp. 32-36. 
ended immediately and a minor disagreement between the Russian and American representatives. Mr. Andre Gromyko, the Soviet Representative, wanted the five permanent members of the Security Council to be the nucleus of the United Nations Special Committee on Palestine. Mr. Warren Austin, the American representative, objected, possibly because he did not want the Soviet Union to have anything to do with the direction of affairs in Palestine. But the Russians were determined to have a say; so Mr. Gromyko spoke in favor of Zionist aspirations. ${ }^{1}$ This was a great surprise since Stalin was a known anti-zionist ${ }^{2}$ and since only the previous summer the Soviet Union took the exact opposite view. Why did the Soviets take such a stand then? Soviet foreign relations papers would help supply the answer, but such papers are not available from the Soviet Union. Had Soviet strategic planners perceived then that partition would not bring peace, making it possible for them to acquire the influence they always longed for in that area? Or was it a strike against Anglo-American cooperation? Did they think they could export Russian communists to exploit the situation? According to Charles Issawi,

Their objective was a negative one: u1timately to eliminate a11 western power in the Middle East and in the meantime to weaken the western position in every way, militarily, politically, economically and culturally ... Hence the task of the Soviets was easy. All they had to do was to ally themselves with whatever force happened to be fighting the West: Syrian and Lebanese nationalism in 1945, Zionism in 1947-9, and, since 1955, Arab nationalism led by Egypt and Syria. 3

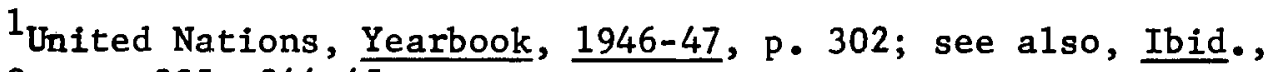
1947-48, pp. 235, 244-45.

${ }^{2}$ Svetlana A1liuyeva, Twenty Letters to a Friend (New York: Harper \& Row, 1967), p. 196.

${ }^{3}$ Charles Issawi, "Middle East Dilemmas: An Outline of Problems," Journal of International Affairs, XIII, no. 2 (1959); 102. 
The UNSCOP submitted its report to the General Assembly in September 1947. The majority recommendation was for partition. ${ }^{1}$ An Ad Hoc Comittee was formed to determine how partition could be carried out. Britain warned that she would not use her troops to enforce the plan should the Arabs or the Jews not accept it. ${ }^{2}$ The American member on the Ad Hoc Committee, Herschel Johnson, proposed that the Negev and Jaffa be part of the Arab state. When Weizmann learned of this proposal, he immediately requested to see Truman and succeeded in doing so on the 19th of November, 1947. Truman was so Impressed that he telephoned Johnson at the United Nations instructing him to drop his proposal and support the inclusion of the Negev in the Jewish State. ${ }^{3}$

The Arabs were informed by the State Department that, though the American government was going to vote for partition, she would not apply pressure on other members to do so. 4 Truman says that, although he was urged by some Zionists to press other nations into favorable votes, he "has never approved of the practice of the strong imposing

${ }^{1}$ See, United Nations, General As sembly, Special Committee on Palestine, Report on Palestine: Report to the Second Session of the General Assemb1y, 1947 (New York: Somerset Books, 1947); United Nations, Yearbook, 1947-48, pp. 231-32; Jorge Garcia-Granados, The Birth of Israel: The Drama as I Saw It (New York: Knopf, 1948).

2 Documents on American Foreign Relations, 1947, IX, 724-30; United Nations, Yearbook, 1947-48, p. 232.

3etzmann, Trial and Error, Pp. 458-59; Herbert Feis, The Birth of Israel: The Tousled Diplomatic Bed (New York: Norton, 1969), $\mathrm{p} \cdot \frac{1}{44 .}$

${ }^{4}$ Ibid., Pp. 45-66. 
their will on the weak." 1 If this is a denial by Truman that American pressure was not applied, it does not represent the truth. Sumner Welles says,

By direct order of the White House every form of pressure, direct or indirect, was brought to bear by American officials upon those countries outside the Moslem world that were known to be either uncertain or opposed to partition. Representatives or interuediaries were employed by the White House to make sure that the necessary majority would at length be secured. 2

The Arabs opposed partition as grossly unfair and undemocratic. The Jewish minority was being allotted the best part of Palestine. Besides, the proposed Jewish state was going to have as many Arabs as Jews. Therefore, the right of the Arab half needed to be recognized if the principle of self-detemination meant anything. Under the proposed partition, their right for self-determination was being denied, while the Jews, most of them still foreigners, were entitled to it. They even denied the legal and moral obligation of the United Nations to partition Palestine against the wishes of its legitimate inhabitants. ${ }^{3}$ Forrestal, seeing the danger to American interests, tried unsuccessfully to effect a change in American policy. 4 State Department officials had apprently given up on the issue by then, since it was bringing them only embarrassment and loss of face.

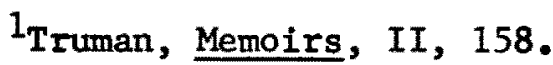

${ }^{2}$ Sumner Welles, We Need Not Fail (Boston: Houghton Mifflin Co., 1948), p. 63 .

${ }^{3}$ Kermit Roosevelt, "The Partition of Palestine," Middle East Journa 1, II (January, 1948), 14; United Nations, Yearbook, $\underline{1947-48}$, pP. 232-33.

4ruman, Memoirs, II, 133, 140; Forresta1, Diaries, pp. 360, 411. 
When the Soviet Union announced that she would vote for partition, needless to say, the Zionists were overjoyed while the Arabs' anger and disay mounted. Arab representatives tried in vain to delay the vote on the resolution. The President of the U. N. General Assembly ruled that it should be voted immediately. Efforts in support of Arab demands by several nations also failed. When the partition resolution was passed on November 29, 1947, by a majority of 33 votes against 13 (and 10 abstentions), the Arab representatives announced that they would not abide by it. 1 They have kept their word. One Arab spokesman, Prince Feisal of Saudi Arabia, said to the U.N. Assembly,

We have felt like many others, the pressure exerted on various representatives of this Organization by some of the big powers in order that voting should be in favor of partition . . . . My Government holds responsible those parties that hampered all means of cooperation and understanding. 2

Dr. Fadhil al-Jamali, the Foreign Minister of Iraq, added,

The fact that we failed to win your support is not the result of a lack of good will on the part of the members of this assembly. It is not due to a lack of understanding on the part of most of you. On the contrary we understand very we 11 that it was great pressure and great influence that worked itself through the Ad Hoc Committee and through the General Assembly to direct the matter in a course which led to this conclusion. 3

\section{v. COMPOUNDING THE PROBLEM}

War broke out even before the mandate was terminated. Both America and Britain knew a11 along that the Jews would be able to smash Arab

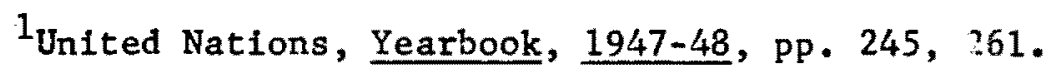

2United Nations, General Assemb1y, Official cords, 128

Plenary Meeting, 1947, vo1. II, p. 1425, Appendix A, (III).

${ }^{3}$ Ibid., p. 1427. 
resistance when the time came. 1 The worry in the United States was over the suspicion of what Russia might do if the United States did not intervenc. Both Scate and War Department officials did not want to see the Untted states fight against the Arabs in case the Soviets decided to assist the Arabs. ${ }^{2}$ The United States, therefore, started considering the possibility of a trusteeship instead of partition. Again Weizmann requested to see Truman, but the President was not willing to see any Zlontst spokesman at that time. Eddie Jacobson, Truman's former partner in the haberdashery business, ${ }^{3}$ interceded. Truman recalls that when Weizmann saw him on March 18, he was gratified and "reached a full understanding of my policy and that I knew what it was he wanted." 4 The next day the United States representative at the United Nations declared that, since partition could not be implemented peacefully, it should be suspended. 5 The Zionists attacked the State Department and especially Loy Henderson. President Truman took the Palestine affairs from Henderson and placed them in the charge of Major General Hilldring, an ardent pro-Zionist. ${ }^{6}$ And to comfort Weizmann, he asked his adviser, Samuel Rosenman, to assure him that this was not a change in the United States long-range "policy he and I talked about."7 Truman

1Winston Churchi11, The Second World War ( 6 vols.; Boston: Houghton Mifflin, 1948-53), V, 688; Feis, Birth of Israel, p. 59.

2 Forresta1, Diaries, p. 410.

3 Jonathan Daniels, The Man of Independence (New York: Lippincott, 1950), p. 318; Feis, Birth of Israel, p. 53 .

4Truman, Memoirs, II, 190.

5Forresta1, Diaries, p. 360; Westerfield, Foreign Policy, p. 233.

${ }^{6}$ Acheson, Present at the Creation, P. 173.

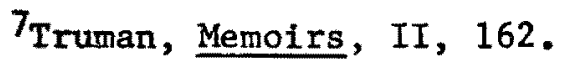


continues, "He knew, I am sure, what the direction of American policy was."1

It appears that Truman, by then, had already made up his mind to recognize the Jewish state when it came into existence. Feis states that on Apri1 12, 1948, he authorized Jacobson to inform Weizmann of this decision and to reassure him that he stood by his promises. ${ }^{2}$ Weizmann, upon advising Ben Gurion to proclaim the state, notifled Truman that this would take place on May 14, at midnight. ${ }^{3}$ Truman, determined to grant immediate recognition, got in touch with the Jewish Agency to coordinate the action. Truman claims that Secretary Marshall supported his policy. 4 It was revealed, however, that he objected to $1 t$, but when he learned that Truman was already on record for a Jewish state, he gave up. 5 There was no way to change American policy against the wishes of the President. Secretary Byrnes, before him, had tried and falled. Byrnes is even reported to have washed his hands of the Palestine policy. 6

When Israel was proclaimed a state as planned, the United States' recognition was declared only 11 minutes later. Truman's decision was a purely personal one. His State Department and his United Nations

${ }^{1}$ Ibid.

2 Feis, Birth of Israel, p. 59.

3Truman, Memoirs, II, 164.

${ }^{4}$ Ibld.

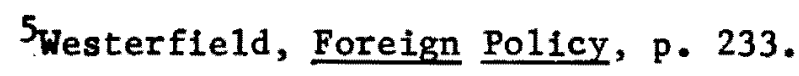

${ }^{6}$ Forrestal, Diaries, p. 310; Acheson, Present at the Creation, p. 169. 
mission were informed only after action was taken. ${ }^{1}$ He did not trust them, It seems, and believed they wanted to block recognition. 2 Truman recn11s, "Charlie Ross, my press secretary, handed the press the announcement." 3 He adds, "I was told that to some of the career men at the State Department this announcement came as a surprise. It should not have been if these men had falthfully supported my policy."4 Truman further reveals, "I wanted to make it plain that the President of the United States... is responsible for making forelgn policy, and furthermore, that no one in any department can sabotage the President's policy." 5

Israel won the war, partly due to substantial assistance from abroad--foreign money, arms, and volunteers. ${ }^{6}$ One grave consequence of the war was to drive about one million Palestinians from their homes and property. 7 Unmindful of the suffering of the new refugees, despite his claims at sympathy and philanthropy, Truman declared on October 28, 1948, "Israel must be large enough and strong enough to make its people

${ }^{1}$ Ib1d.; Daniels, Man of Independence, p. 319; Cecil Van Meter Crabb, Jr., Bipartisan Foreign Policy (Evanston, I11.: Row, Peterson, 1957), p. 124 .

2 Truman, Memoirs, II, 164 .

3. Ibid.

${ }^{4}$ Ibid.

5Ibid., 165.

6 New York Times, May 16, 23; June 6, 11, 14; July 1; October 11, 1948.

7Wi11lam Reitze1, United States Foreign Policy, 1945-55 (Washington, D.C.: Brookings institution, 1956), pp. 216-17. 
self-supporting and secure."I It was mainly through American support that Israel was established; it was through her influence that partition was adopted; she was the first nation to grant de facto recognition; and her President was promising her (Israel) economic and logistic support.

What else could be done to aggravate and embitter the Arabs? They placed pirimary blame on the United States and Britain and almost Ignored the key role Russia played. If Russia's stand was meant to create such a situation, in the first place, it was indeed a masterly stroke of remarkable foresight and genius. What followed since then only confirms this belief.

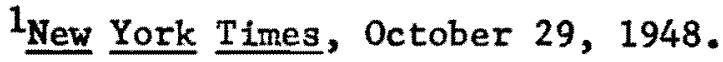


CHAPTER III

THE ALIENATION OF THE ARAB WORLD

Up to 1946, the main concerns of the United States Government had been safeguarding and expanding American oil business in the Middle East and securing and maintaining normal trade relations with Middle Eastern states. The United States neither sought control of Middle Eastern States nor wished to interfere with their affairs. The fact that the United States left the area soon after the war ended in 1945 was a clear indication of this post-war American attitude toward the Middle East. Of the twenty-seven bases the United States operated and maintained in the area, only the one in Tripoli was kept under American control. The new base at Dhahran, secured in early 1946, was to be maintained and used by the United States for a period of three years. 1 The American involvement in Iran beginning in 1946, and the declaration of the Truman Doctrine on March 12, 1947 marked the starting points of an era of growing American involvement in Middle Eastern affairs. American involvement came as a response to the challenges of the Soviet Union. In the Middle East, the United States began to adopt the British outlook on defense. This identification with Britain was finally to prove as diasterous to United States interests in the area as her pro-Zionist policy, and marked the first significant reversal of American traditional policy in the Middle East. It came as a result

\footnotetext{
$1_{\text {New }}$ York Times, February $8,1946$.
} 
of a necessity felt by the United States to establish a situation of strength in the Middle East to replace that of the British and French, whose influence had been greatly weakened. 1

The preservation of the status quo became the primary concern of the United States. It was considered to be an effective means of maintaining the traditional Western influence in the area, of insuring the safety of communication routes and the supply of oil, and of discouraging Soviet attempts to gain influence in the area. The Truman Doctrine was successful in Greece and Turkey. But following its declaration, Czechoslovakia fell to the communists, Berlin was blockaded, mainland China came under communist rule, and a conflict in Korea erupted. Such events made it appear to the Western powers that the status quo in the Middle East could be maintained only through a Middle Eastern military defense alliance with the West. The assumption on the part of the Western powers that the states of the Arab World would welcome an alliance with them in the same way Greece and Turkey had welcomed American aid after Britain's withdrawal proved erroneous. ${ }^{2}$

This assumption was based on an invalid rationale because the Arabs were far from being disturbed by a Russian threat. They were

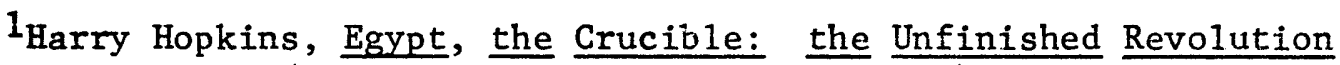
in the Arab World (Boston: Houghton Mifflin, 1969), p. 189; John Coert Campbe11, Defense of the Middle East: Problems of American Policy (New York: Published for the Council on Foreign Relations by Harper, 1958), pp. 13-16.

${ }^{2}$ Ibid., pp. 23-28, 32-35; Malcolm Kerr, "'Coming to Terms with Nasser': Attempts and Failures," International Affairs, XIIII (January, 1967), 68; R. K. Ramazani, "Changing United States Policy in the Middle East," The Virginia Quarterly Review, XI (Sumer, 1964), 369-71. 
preoccupied with their struggle against the remnants of British "imperialism" and with the challenge posed by political Zionism. Having suppurted Zionism, the United States could not possibly expect the Arabs to be more than lukewarm toward her policies in the area. ${ }^{1}$ The growing Anglo-American cooperation in seeking to maintain control over strategic positions in the Middle East made it all the more difficult to find a common ground for cooperation with the Arabs. ${ }^{2}$ Moreover, the United States sought the friendship of local regimes to safeguard her interests and those of her allies. But those regimes were often at odds with each other. Thus America's friendship with one or the other of Middle Eastern countries got her involved in their local quarrels. The United States, on the other hand, could not avoid being involved by staying out because her strategic position and her influence would have been threatened. ${ }^{3}$

\section{ATTEMPTS AT COOPERATION}

Despite these trends in American policy, the Egyptian government appeared ready and willing to establish normal relations with the United States. Anxious to have her army reequipped, Egypt sought U. S. military assistance soon after World War II. During April and September of 1947, Washington hosted first the Egyptian army Chief of

1Campbe11, Defense of the Middle East, pp. 35-38.

2Muhammed Shafi Agwani, The United States and the Arab World, 1945-1952 (A1igarb: Institute of Islamic Studies, Muslim University, 1955), PF. 111-12.

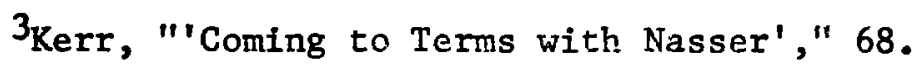


Staff General Ibrahim Atallah Pasha and then Prime Minister Nokrashi Pasha, who were out shopping for arms. Through such visits and diplomatic exchanges, Washington was made aware of Egypt's deep resentment of the British presence on her soll. Egyptian officials left an Impression that closer cooperation between the United States and Egypt was possible, had it not been for the occupation by Britain of the Suez Zone base. America's Palestine policy in 1948 added another obstacle in the way for better U.S.-Arab relations.

America's pro-Zionist policy and her cooperation with Britain to hold on to Western strategic positions in the Middle East alarmed the Arabs and aroused their doubt and suspicion of her motives. There seemed to be very little hope, therefore, that the Point IV Program (announced January 20, 1949, by President Truman) could attain any significant success in the Arab world. The idea of the Program was that, in order to prevent uncomitted peoples from embracing communism and becoming satellites of the Soviet Union, it was necessary to "help them help themselves." Such economic and technical assistance as offered through the Point IV Program would, it was hoped, work for stability and economic strength and win friends for the United States. But this firgt concrete effort to encourage U.S.-Arab cooperation proved a failure. According to the Egyptian Economic and Political Review, the Point IV Program carried with it the stigma of "power politics." National governments who accepted it came under serious public scrutiny. The chances for the United States were open to launch a more realistic 
program, that met the needs felt by the area's people. 1

What the countries of the Middle East needed, according to H. Paul Ca-tleberry, was sufficient funds to finance "a few big undertakings that w11 produce immediate results in the form of new jobs and high income, rather than surveys followed by reports setting forth needs that they coùld have easily outlined themselves." 2 The amount of aid granted under the Point IV Program was too little as compared to the ald given Israe1. The Program was viewed, therefore, as a device not meant to effect a significant increase in the national product of the countries of the Middle East or to improve the lot of the povertystricken masses. In short, the Point IV Program was rejected by Syria, tried and dismissed by Saudi Arabia, regarded as unimportant by Iraq, accepted but immobilized in Jordan and Egypt, and exploited only by Lebanon ${ }^{3}$

Although Syria was the first Arab country to flatly reject the Point IV Program and to denounce it, her relations with the United States continued somewhat undisturbed until 1949. The United States legation in Damascus was trying for sometime to stimulate a program of reform in Syria through the Quwatly regime. The legation hoped that either the Quwatly regime or a replacement would soften down on

1"From the Shores of Tripoli to the Oilfields of Arabia," Egyptian Economic and Political Review (International Edition, June, 1955), p. 22; for an analysis of the Arab view of Point IV, see George Hakim, "Point Four and the Middle East: a Middle East View," The Middle East Journa 1, IV (Apri1, 1950), 183-95.

${ }^{2} \mathrm{H}$. Paul Castleberry, "The Arabs' View of Postwar American Foreign Policy," Western Political Quarterly, XXII (March, 1959), 20.

${ }^{3}$ Richard H. Noble, "American Policy in the Middle East," Journal of International Affairs, XIII (No. 2, 1959), 117. 
the Israeli issue and move toward a peaceful settlement. When the Quwatly establishment showed no signs of any intention to liberalize the system or institute reform, American ag-nts got in touch with Husni al-Zaim, then Chief of Staff of Syria's army, and gave him instructions on how to effect a coup against Quwatly. Husni a1-Zaim was to overthrow the elected republican government to stem corruption and inefficiency and begin anew. Accordingly, on March 30, 1949, al-Zaim's plans materialized in a bloodless coup. 1 American officials were disappointed, however, for he not only followed an independent course, but within six months he was toppled by a coup staged against him by Colonel Sami al-Hinnawi. 2 Before the year was over, Hinnawi himself was overthrown by Lieutenant Colone1 Adib a1-Shishak1i. ${ }^{3}$ Thus the United States helped start a chain reaction in Syria that, by degree and at every oncoming stage, displayed a mood that became increasingly anti-American. 4

Oil was a major interest for the United States and her allies. But there were few problems connected with it as far as U.S.-Arab relations were concerned. In fact, the agreement with Saudi Arabia to share oil revenues on a $50 / 50$ basis "made the extremely one-sided British agreements in the Gulf and Iran look like what they indeed

${ }^{1}$ For more detail on the a1-Zaim coup, see Gordon H. Torrey, Syrian Politics and the Military, 1945-1958 (Columbus: Ohio State University Press, 1964), pp. 121-31.

$$
\begin{aligned}
& 2_{\text {Ibid., Pp. 143-57. }} \\
& \text { 3Ibid., Pp. 162-97. }
\end{aligned}
$$

4Miles Copeland, The Game of Nations: the Amorality of Power Politics (New York: Simon and Schuster, 1969), pp. 49-56; Harry B. E11is, Challenge in the Middle East: Communist Influence and American Policy (New York: Ronald Press, 1960), Pp. 32-34. 
were, a ruthless exploitation of local resources without any regard to the needs and rights of the inhabitants." The pay and the treatment at the American oil companies actually caused a sensation. 1 The American oil companies were we11 on their way to gaining a larger share of Middle East oil. According to Marian Pearl,

In 1946, the British still controlled ha1f the entire interest in Middle Eastern oil compared to $35.3 \%$ for American companies. However, by 1955, after the Iranian dispute resulted in a consortium giving American companies a $40 \%$ share in a formerly al1-British concern, the American share in Middle Eastern oil jumped to $58.4 \%$ while Britain's aropped to $35.9 \% .2$

But the dominating American interest, which was back in the minds of American and British policy planners all along, was the concern over Mddle East defense. Western officials realized there were obstacles, but they never lost hope of binding the Arab states to some sort of a Western-sponsored collective defense system against the Soviet Union.

\section{ARAB REACTION}

Fearful that participation in Western-sponsored alliance might Involve them in an East-West confrontation, several Arab states, led by Egypt, formed the Arab League Collective Security Pact. The plans for this pact were drawn up on October 3,1949 , and finally approved on June 7, 1950. By doing so, those Arab states were attempting to create a collective defense system that was independent of the Western powers. Besides their fear of involvement in a super-power

1"Isolation or Entanglement," Egyptian Economic and Politica1 Review (Internationa1 Edition, December, 1956/January, 1957), p. 14.

2Marian A. Pear1, "America in the Middle East," Contemporary Issues, X (May/June, 1960), 83. 
struggle, they had the fear of economic domination, exploitation, and loss of independence. Moreover, the United States campaign against Russia did not concern them. One of Cairo's leading journalists at the time, Fikry Abazah, said, "The United States has becone a camp dressed against the Soviets.. What is this al1 about? There is nothing but a spectre that is being used as a scarecrow and is called communism." 1

As the war in Korea broke out in June, 1950, opposition to it came loud and clear from the Arab camp. As a member of the United Nations Security Council then, Egypt abstained from voting for the United Nations resolution to aid South Korea. Demonstrations against American involvement in Korea erupted In Syria, Iraq, Tunisia, and Egypt, which denounced American policy in Korea and blamed the Western powers for the war in that country. 2 Egypt's policy received unwavering oupport from the Arab public and from leaders of Arab pub1ic opinion. The leader of the Iraq 1 National Democratic Party is quoted as saying, "Egypt has taken a sound stand by declaring her neutrality and I am convinced a11 the Arab nations support her. I hope none of the Arab govermments will act contrary to the wishes of their people." 3

But though the Arab public generally supported Egypt's policy, their governments were far from being united on this 1ssue. By voicing their support to the American involvement in Korea, the ruling classes of Saudi Arabia, Jordan, Iraq, Syria, and Lebanon, undermined Egypt's

ITe Egyptian Gazette, Apri1 20, 1950.

2New York Times, Ju1y 2, 1950.

3Ibid., Ju1y 3, 1950. 
policy of non-alignment. Despite this setback, leaders of Arab public opinion continued to press for and campaign in support of neutrality unt1l eventually it became impossible for the politicians to ignore its force. The pro-American actions were taken in July 1950. Within a period of six months both Syria and Iraq came out in support of neutrality. During the Arab League session of January 1951, under public nationalist pressure, Premiers Nuri a1-Said of Iraq and Nazim a1-Qudsi of Syria had to declare a change of policy in support of non-alignment. ${ }^{1}$ Walter Laqueur observes that "Of all the Middle Eastern states, only Turkey came out openly on the side of the United Nations and decided to send an armed contingent to Korea." Laqueur goes on to say that,

Several Arab newspapers were openly jubilant at the reverses of the United Nations armies, seeing in them a just retribution for the Organization's support of Israel. By her abstentions in the Security Council, Egypt regained in the Arab world some of the prestige she had lost in the Palestine War, while a politician of the Syrian People's Party and future Premier, Shaikh Ma'ruf al-Dawalibi, declared that the only way to prevent a third world war was to sign a non-aggression pact with the Soviet Union. ${ }^{2}$

\section{MIDDLE EAST DEFENSE PROPOSALS}

Meanwhile, concerned over the maintenance of stability in the area and especially over the security of the state of Israel, the United States joined Britain and France in issuing the Tripartite Declaration of May 25, 1950. The Declaration, by opposing the use or threat to use force ir. the area, served the functicn of keeping the Palestine

$1_{\text {Ibid. }}$, February 11, 1951.

2Walter 2. Laqueur, Communism and Nationalism in the Middle East (New York: Praeger, 1957), p. 256. 
frontier quiet and guarding the 1949 armistice agreement between Israe 1 and the Arab states. It might have also been intended to prevent possible action against Jordan, which annexed the Arab West Bank against the wishes of Egypt and Saudi Arabia. ${ }^{1}$ It also governed the supply of arms to the states of the Middle East until Syria and Egypt made their arms deals with the Soviet Union in 1955.

The United States espousal of the principle of self-determination did not prevent her from trying to preserve the influence and prestige of her major allies. The remaining British and French military bases and related facilities were essential for the protection of common interests in the region. ${ }^{2}$ The attitude displayed by the Arabs, however, confronted the United States government with a dilemma. It became obvious that backing the British in the Middle East would further allenate the Arabs. On the other hand, to press England for complete evacuation would deal a deadly blow to Western defense plans. The United States chose to back Britain. Little, if any, attention was given the idea of supporting neutrality and Arab nationalism. This proved to be an unfortunate choice that plagued U.S.-Arab relations ever since.

The United States, it was thought, should try to forge an alliance binding the Middle East with Western allies to secure the southern flank of NATO and to check Soviet influence. This resort to military pacts

$1_{J a c o b}$ Coleman Hurewitz, Diplomacy in the Near and Middle East (2 vols.; New York: Van Nostrand, 1956), II, 308-9.

2 Jacob Coleman Hurewitz, ed., "Soviet-American Rivalry in the Middle East," Academy of Political Science Proceedings, XXIX (March, 1969), 8. 
was an automatic response to the Soviet challenge, which appeared to be mainly military. Various events in Europe and Asia gave credence to that line of thinking. "Hence the rather mechanical attempts," says John Campbe11, "pursued without sufficient regard to the political conditions and consequences, to form with the Middle Eastern nations an Allied Middle East Command or a Middle East Defense Organization."1 Egypt and the other Arab states were more concerned over the problems of Western "imperialism" than over Russia. At the same time, Iran was In the middle of a dispute over oil with Britain. "In an atmosphere poisoned by these bitter disputes, where was the basis," asks Campbe11, "for partnership and pacts of mutual defense?"2

Cold war considerations, however, were the governing preoccupations of the United States and Britain. But major cold war confrontations at the time were all outside the Middle East. The communist coup in Czechoslovakia, the Berlin blockade, the fall of mainland China to the communists, the war in Korea, and the European and Japanese need for o11 were not of immediate concern to the area's peoples. ${ }^{3}$ Thus while the West busied itself with defense pacts aimed at resisting Soviet threats, especially in areas such as the Middle East, the Arab fears were not of Soviet communism but of Israeli expansionism and British colonialism. The fact that Egypt was striving to secure British evacuation was sufficient reason to keep her from enlisting Britain's

${ }^{1}$ John Coert Campbe11, "America and the Middle East," India Quarterly, XV (April/June, 1959), 143.

2 Ibid.

3onroe, "Mr. Bevin's 'Arab Policy'," pp. 9-10. 
atd in defending her territory. But global considerations weighed very heavily on the American agenda, making it difficult for America to be sensitive to the desires and aspirations of the Arabs and to avoid misjudgment and error in her Mideast policy. Such calls for neutrality as the one issued by Akram al-Hurani in January 1950, in his Arab Socialist Party's program, went unheeded. Al-Hurani called for an Arab foreign policy "free from all foreign orientation or influence." In its manifesto of January 24, 1951, the Ba'th Party issued a warning to the Arab League "against making any gesture of adhesion to one or other of the two blocs." 1 In answer to Western efforts to align the Arab world and to come to terms with Israel, a public Arab cry arose asserting the Arab wish to choose Russia over falling prey to Israel. On March 12, 1950, Sheikh Mustafa al-Siba'1, addressing an Islamic Socialist Front rally in Damascus, declared, "We are resolved to turn towards the eastern camp if the Democracies do not give us justice... To those who say this eastern camp is our enemy we would answer: when has the Western camp been our friend? . . We will bind surselves to Russia were she the very devil."2

It should not have been surprising, therefore, that the Western efforts at pact-making in the Middle East came against a wall of strong Arab resistance. When the West began shopping for a local key ally, it was not easy to make a decision. Iran, besides being in financial

${ }^{1}$ Quoted in Patrick Seale, The Struggle for Syria: A Study of Post-war Arab Politics (New York: Oxford University Press, 1965), p. 103 .

2 Ibid., p. 102. 
troubles, was locked in dispute over ofl with Britain, the climax of which was the nationalization of her oil industry. It was therefore unthinkable to expect her to welcome a pact in which Britain was a leading member, and especially whlle Dr. Mossadegh was still in power. Israel would have been a worse choice, for no Arab state would join a pact in which Israel was a leader or a member. Arab resentment of Turkey made her no better choice either. The choice fell on Egypt, being a central power and the strongest Arab state. It was thought that Egyptian leadership, participation, or, at least, toleration, was essential for the success of Western defense plans. ${ }^{1}$ The facts were, however, that the efforts to organize the Middle East into a Western-sponsored defense system were doomed to fail no matter where they started. The political, social, and psychological mood displayed sufficient evidence of resistance and opposition to such plans.

Nevertheless, unmindful of the moods, desires, aims, fears, and hopes of the area's peoples, the Western powers went ahead trying to implement their plans for securing and defending the Middle East. In early 1951, Middle Eastern capitals began to be frequented by officlal Western visitors. Several conferences were held among Western military officers to discuss Middle East defense. During January, March, and Apr11 of 1951, the United States took part in a series of conferences held in Malta with Britain, France, and Italy. United States envoys, led by Mr. George C. McGee, Assistant Secretary of State for Near

${ }^{1}$ Campbe11, Defense of the Middle East, pp. 40-43; William Roe Polk, The United States and th Arab World (Cambridge, Mass.: Harvard University Press, 1969), p. $\frac{27}{\text {. }}$. 
Eastern, South Asian and African Affairs, met in Istanbul, Turkey, during February of 1951. Following their conference, Mr. McGee toured the area expressing the hope that the states of the Middle East would try and emulate the example of Greece, Turkey, and Iran to achieve the same degree of progress in military preparedness those countries reached through their association with the West. But this call of his, coupled with exhortations to wake up to the need for general defense and security arrangements not only fell on deaf ears, but demonstrations broke out, especially in Syria, protesting such visits by Western officials and military officers. ${ }^{1}$ In a message to the Secretary of the Arab League, Salih Harb, the leader of the Society of Muslim Youth in Egypt, wrote,

the Arab peoples, after a11 they have suffered, will not accept to be sold in the name of democracy on the British imperial market . - I we/ ask you, in the name of the Arab peoples, to proclaim the most absolute neutrality. We wish neither to support Communism nor to defend imperialist democracy. ${ }^{2}$

Western efforts persisted in spite of the protests, demonstrations, and manifestoes. On June 18, 1951, the United States renewed the Dhahran base lease with Saudi Arabia for a period of five more years. On September 20, 1951, C-eece and Turkey were invited to join the NATO alliance. On October 14, 1951, Egypt received a four-power proposal to join an Allied Middle East Command. ${ }^{3}$ The United States, Great Britain, France, and Turkey handed Egypt drafts of the plans and

${ }^{1}$ Seale, Struggle for Syria, p. 103.

2a1-Misri (Cairo), January 23, 1951, quoted in Ibid., p. 104.

3U.S., Department of State, Bulletin, XXV (October 22, 1951), 647-48. 
proposed that she join and occupy a place equal to each of them. Australia, New Zealand, and the Union of South Africa were to join as associate members, and AMEC was supposed to have an undefiriad relationship with NATO. 1 Aware of Egypt's attitude toward British occupation of the Suez Canal base, and believing that her unwillingness to discuss dëfense plans was due to that British presence, the proposal included a British statement to the effect that, if Egypt joined and permitted the use of her facilities, including the Suez base, British forces not assigned to the Allied Middle East Command would be withdrawn and the Ang1o-Egyptian treaty of 1936 would be suppressed. In the Sudan, however, Britain would not be able to meet Egypt's demands. ${ }^{2}$ On October 10, 1951, three days before the draft proposal was presented to Egypt, Secretary of State Dean Acheson released a statement to the press saying,

It is the belief of the United States that a solution to the Anglo-Egyptian question can be found through these proposals . . . Land/ should serve as a sound basis of an agreement which will not only satisfy the interests of all parties concerned but also contribute to the defense of the free world in which the Middle East plays such an important role. 3

\section{EGYPT'S REJECTION AND ITS IMPACT}

Egypt's response was immediate. Her government flatly rejected the proposals and abrogated the treaty of 1936 and the agreement of

${ }^{1}$ Halford L. Hoskins, "Some Aspects of the Security Problem in the Middle East," American Political Science Review, XLVII (March, 1953), 188-98.

2Kerr, "Coming to Terms with Nasser'," 70; Polk, The United States and the Arab World, p. 270.

${ }^{3}$ U.S., Department of State, Bulletin, XXV (October 22, 1951), 647. 
1899 with Britain. According to Halford Hoskins, "the Egyptian Parliament had unanimously adopted measures abrogating the treaties under which Great Britain held sway in the Sudan and maintained bases in the Suez Canal zone."1 The proposals overlooked Egypt's constant and persistent calls for total evacuation of British troops and the union of Egypt and the Sudan under one crown. In giving Israel assurances that her interests would be carefully guarded in working out Middle East Command plans, the Western allies ignored a genera1 Arab feeling of resentment toward the West for its support of Israe1. In fact those assurances multiplied Arab fears of Israel itself.

By her rejection of the defense proposals and her abrogation of the Ang10-Egyptian treaty of 1936 and the agreement of 1899, Egypt and the Wafd Party government demonstrated their commitment to the policy of neutrality--a policy, which was described by Mr. George McGee as "a disturbing factor... in the Middle East."2 Egypt's government was under Egyptian pub1ic pressure to keep Egypt neutral and the Nile Valley united. ${ }^{3}$ The climate of the time made it inevitable for Egypt to turn down the defense proposals. By accepting them, Egypt would have only supported another means of prolonging British occupation and continuing an unequal relationship with Britain with

\footnotetext{
${ }^{1}$ Hoskins, "Some Aspects of the Security Problem in the Middle East," 194. 645.

2U.S., Department of State, Bu1letin, XXV (October 22, 1951),

${ }^{3}$ Po1k, The United States and the Arab World, p. 270.
} 
the backing of the United States. ${ }^{1}$ In August 1951, on the anniversary of the signing of the 1936 Anglo-Egyptian treaty, ant1-British popular demonstrations broke out and one attacked the embassies of both Britain and the United States. 2 Under such circumstances, "Even the corrupt and cynical Farouk-Nahhas Pasha regime," says Senator Humphrey, "declined to accept an arrangement that would perpetuate the presence of the British in Suez." 3

In reply to Egypt's actions, the United States joined Britain in denouncing and condeming the Egyptian stand. On October 17, Secretary Acheson, in a press release, said,

The U.S. Government must reaffirm its belief that the action of the Egyptian Government with respect to the Anglo-Egyptian Treaty of 1936 and the agreements of 1899 regarding the Sudan is not in accord with proper respect for international obligations. For its part the U.S. Government considers the action of the Egyptian Government to be without validity. 4

To Egypt's response that the defense proposals could not be considered as long as British forces continued their presence in Egypt and the Sudan, Mr. Acheson replied that the

proposals were formulated by the nations interested in the welfare and security of the Middle East after the most intensive and thorough consideration of the special problems of the area. The invitation to join with other free nations of the free world

${ }^{1}$ John Coert Campbe11, The Middle East in the Muted Cold War (Demver: University of Denver, 1964), Pp. 5-6; Campbe11, Defense of the Middle East, pp. 43-44.

2 Seale, Struggle for Syria, p. 112 .

${ }^{3}$ Hubert H. Humphrey, "A Chronology of Failure," Reporter, XIX (August 7, 1958), 12 . 702-3.

4U.S., Department of State, Bulletin, XXV (October 29, 1951), 
in a joint cooperative effort to make the world safe from aggression was wholly consistent with the independence and sovereignty of Egypt.1

But, regrettably, those thorough considerations did not include previous consultations with Egypt. This cannot be considered but a serious blunder on the part of the four powers. Egypt should have at least been included in the preliminary discussions. ${ }^{2}$ On October 25 , 1951, the Egyptian Ambassador to the United States Kamil Abd-a1-Rahim Issued a statement to the press in which he said that, after the Egyptian government's careful study of the defense proposals, the conclusion arrived at was that they were only a means of perpetuating the occupation of Egypt "not only by Britain but also by other powers, an occupation against which Egypt has been rising and clamouring for seventy years." The Ambassador did not fail to point out that the proposals came as a surprise to the Egyptian govermment. "Egypt was never consulted beforehand on the joint proposals presented to her," he said, "was not invited to participate in their formulation and she did not know of the contents except on the day of their presentation." 3

Among the states informed of the proposals was Syria. Thousands of demonstrators took to the streets in Syria's cities and telegrams were sent "to the Prime Minister, to the Security Council, to Muslim and Arab states and to a number of foreign powers, pledging support

$$
\text { I Ibid., } 702 .
$$

${ }^{2}$ Hoskins, "Some Aspects of the Security Problem in the Middle East," 194; Campbe11, Defense of the Midd1e East, p. 43.

${ }^{3}$ Egyptian News, October/November, 1951, quoted in Agwani, The United States and the Arab World, pp. 122-23. 
for the Egyptian cause . . and denouncing the 'imperialist plot of common defense."'1 Though Syria was not asked to comment on the proposa1s, a number of deputies demanded, during a parliamentary session on October 22, a statement from the Syrian Foreign Minister, Faydi al-Atasi. Despite Prime Minister Hasan al-Hakim's efforts to dissuade him, al-Atasi rose up to declare,

Our participation in a system of common defense can only be justified by a clear and real national interest. But I have sought in vain for such an interest... Common defense supposes an enemy against whom it is directed. . . But in what way are we threatened by the enemy aimed at by this project? What evil has the enemy done us? ${ }^{2}$

There followed a cabinet crisis in Syria. Hasan a1-Hakim's government fell and was succeeded by one headed by Dr. Ma'ruf al-Dawalibi, a staunch neutralist. But the latter was soon overthrown (on November 29, 1951) by Col. Adib al-Shishakli's second coup. Al-Shishakli's allies were the progressive nationalists, most important of whom was Akram al-Hurani. "Although he $[\bar{a} 1-S h i s h a k l i]$ West," observed Senator Hubert Humphrey, "he followed, until he was overthrown by those even more intransigent, a policy of nonalignment with the West." 3

Adib al-Shishakli may be considered a forerunner of Nasser. His intial policy views were mainly concerned with Syria. He could not go so far as to accept a limitation on Syria's sovereignty within a Western-sponsored defense system. He attempted to align his policies

${ }^{1}$ Seale, Struggle for Syria, p. 112.

${ }^{2}$ Quoted in Ibid., Pp. 112-13.

3Humphrey, "A Chronology of Failure," 12. 
wth those of Cairo in dealing with the great powers, and is credited with being the first Arab leader to flatly reject the Point IV Program. From the tine he came on the scene in late 1949, his associates and advisers were such neutralist Arab nationalists as Akram al-Hurani. His early association with the PPS did not last very long. He seemed to have been convinced in his own mind that Arabism was the cause to wich Syrla's people would respond. Out of this conviction grew his Idea for the establishment of the Arab Liberation Movement, which he announced on August 25, 1952. In an appeal to al1 the Syrian political parties to join his ALM, al-Shishakli declared in late October 1952 , "Our country is the home of the Arab 1dea.. . I invite you to join the progressive Arab Liberation Movement which is destined to grow until it embraces the whole Arab Fatherland."1 By expanding the Syrian broadcasting services, he pioneered the use of radio propaganda In the Arab world as a weapon of mass education. Damascus Radio set the pace until Nasser established his "Voice of the Arabs" about three years later. 2

The Western defense proposals were rejected for several reasons. The Arabs saw in them the possibility of including Israel. They went against Egyptian interests in ending British influence in Egypt and the Sudan. It was a mistake to include Turkey in a defense system in which the Arabs would be possible partners. She was resented by the

$1_{\text {Barada (Damascus), October 23, 1952, quoted in Seale, Struggle }}$ for Syria, P. 125 . Pp. 205-35.

${ }^{2}$ Ibid., pp. 124-25; Torrey, Syrian Politics and the Military, 
Arabs for her lack of support for the Arab cause in Palestine, for her annexing of the Syrian province of Alexandretta, and for the fact that it was Ottoman rule from which the Arabs, not so long ago, hac fought to gain independence. Besides, having already conmitted herself to an alliance with the West, Turkey was in no position to lead uncommitted states in a conmon defense undertaking. Last, but not least, was the Arab attitude toward the Soviet Union and alliances in general. The Soviet Union was not feared and alliances were seen by the Arabs as new entanglements and as new means of domination. The rejection of the proposals was a further weakening of the West's position without getting what it sought. 1

\section{THE WEST'S PERSISTENCE}

The subject of collective defense was kept alive until early 1953 despite Arab lack of cooperation and rejection and despite Russian protests. On October 24, 1951, the State Department issued a statement to the effect that the establishment of a Middle East defense system was urgent and would be sought with or without Egypt's support or cooperation. 2 Determined to safeguard the Middle East against a supposedly imminent external aggression, the Western powers went to

$1_{\mathrm{H}}$. Paul Castleberry, "The Arabs' View of Postwar American Foreign Policy," 14; J. W. Spain, "Middle East Defense: A New Approach," Middle East Journa1, VIII (Summer, 1954), 253; Ralph H. Magnus, "PoliticalStrategic Interests," in George Lenczowski, ed., United States Interests In the Middle East (Washington, D.C.: American Enterprise Institute for Public Policy Research, 1958), p. 17; Polk, The United States and the Arab Wor1d, p. 270; Campbe11, Defense of the Middle East, pp. 45-48. East," 194.

2 Hoskins, "Some Aspects of the Security Problem in the Middle 
work on new plans. It was understood that, once plans were ready, the Arab states and Israel would be invited to join as members. On November 10, 1951, a joint statement by the United States, Britain, France, and Turkey, set forth the framework for a Middle East Command defense system, to include, in addition to the above-mentioned four powers, Australia, New Zealand, and the Union of South Africa. The plan looked peculiar in conception and did not get the full approval of the United States. 1

After successive modifications and counter British and American proposals, the idea of a Middle East Command was dropped, in August 1952, in favor of a Middle East Defense Organization, similarly peculiar and composed, with the exception of Turkey, of non-Middle Eastern nations. It was to consist of a committee of military officers to help preserve peace in the area and plan for its defense. Secretary of State Dean Acheson bestowed the approval of the United States government on the latter, but considered it essential that the Arab states be consulted before the plans were finalized upon. 2

At least one simple point had been driven home to Western officials, but it certainly was not the most important one. The real feelings and convictions, so effectively demonstrated by those for whom defense was being planned, went unheeded. The conviction by the Western powers of the validity of their views caused them to present essentially unchanged plans for defense. To them that was the only way to defend the Middle East.

${ }^{1}$ Christian Science Monitor, August 7, 1952.

2Hoskins, "Some Aspects of the Security Problem in the Middle East," 194-95. 
vI. SUMMARY AND CONCLUSIONS

1952 ended before the West could achieve any of its defense objectives in the Middle East. The real negative result was the antagonization of the Arabs and their national governments. The Ang10-American views on the area's problems drew closer than ever as the United States began to fully share Britain's apprehensions and fears. The United States attitude and actions convinced the Egyptians that she could not be counted on to play a neutral role in the Ang10Egyptian struggle over the occupation of Suez. It is this suspicion of the United States that foredoomed any Western defense proposal. In general, this was the attitude of most Arab states.

A dominant factor was the Arab lack of enthusiasm for Westernsponsored defense plans. On October 23, 1951, the Foreign Minister of Syria told the Syrian Parliament that his government will reject any proposal for a Western-sponsored Middle East defense scheme. 1 Lebanon's Parliament declared its support for Egypt and, on November 8, 1951, the Arab League Secretary General declared that opposition to the proposed Western alliance was unanimous in the Arab world. 2

"The -ate of any national policy in the international field," says Halford Hoskins, "rests largely with its attractlveness to those toward whom it is directed.... Mutual security depends upon the mutuality of the ends sought and the mearis proposed." 3 Juc:ed by this

${ }^{1}$ New York Times, October ${ }_{24}, 1951$.

2 Ibid., November 9, 1951.

3oskins, "Some Aspects of the Security Problem in the Middle East," 198. 
precept, American policy was rolling on the wrong tracks. United States policy, during the Truman years, was conditioned primarily by cold war considerations and by the "imperial" interests of Great Britain in the Middle East. The Israeli issue, though an extremely sore spot, did not figure very high in the minds of the contestants. At least not yet. 1

There was no doubt in the minds of American post-war policy planners of the need to win Arab goodwill and friendship. The United States, until the end of World War II, was respected in the Arab world. But American statesmen failed to exploit the favorable conditions in the Arab world. Their adoption of policies and courses of action contrary to the wishes and desires of the Arabs made it well nigh impossible for the United States to win friends and influence people in the Middle East. According to the Egyptian Economic and Political Review, President Truman "inaugurated a new era in contemporary American history in which the United States, heavily influenced by Western European points of view, had we11 night accepted European leadership in the conduct of world affairs." 2 With Western allies brought together by strong bonds of common colonial interests, the United States found herself outvoted.

Pre-World War II U.S. relations with foreign peoples were limited and her interests outside the Western Hemisphere were inspired or prompted mainty by sectional rather than national opinion. Therefore, her diplomatis experience was, as William McNeil says, "profoundly

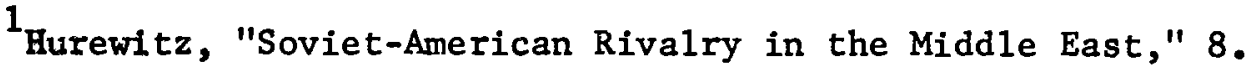
2. $=0$ the Shores of Tripoli to the Oil Fields of Arabia," p. 15.
} 
parochial."1 As late as the year 1940, and after World War II broke out, the American lack of interest in faraway places "was illustrated by a brief note that President Roosevelt wrote with his own hind to dispose of a perplexing file submitted to him by an aide: 'Arabia is too far afield for us. Can't you get the British to do something?'"2 Describing this state of affairs, Henry Byroade said, "The United States has been thrust into the Middle Eastern scene sudden1y and without adequate national preparation." 3 An enormously expanding State Department had to recruit personnel with 1ittle experience in foreign affairs.

To those men was given the responsibility of shaping a policy to contain an enemy threatening the vital interests of the United States. The result was a policy militaristic in concept, and designed to meet what was thought to be a military threat. The basic assumption of this policy was that the only way to limit the enemy's expansion is by a military encirclement of his territory and his intimidation under the threat of nuclear power. For this policy to succeed in the Middle East, Arab friendship and cooperation was necessary. The policy failed because the American diplomat "has tended in general towards erroneous

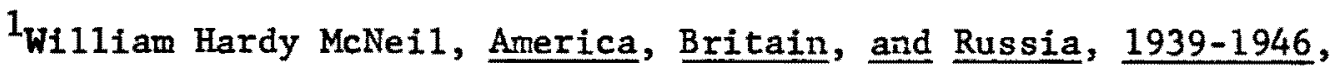
Survey of International Affairs, 1939-1946, Vol. III (Oxford: Oxford University Press, 1953), 761.

${ }^{2}$ Max Neston Thornburg, People and Policy in the Middle East: A Study of Social and Political Change as a Basis for United States Policy (New York: Norton, 1964), p. 5 .

${ }^{3}$ Henry A. Byroade, "The Middle East in New Perspective," U.S., Department of State, Bulletin, XXX (Apri1 26, 1954), 628-33. 
assessment of the strength of Arab Nationalism, and his endeavors to apply policies and methods successful elsewhere has usually found them unsuccessful in the Middle East."1

The first active American involvement in Middle Eastern affairs alienated the Arabs. Great interest had been demonstrated by American. Jews and by the American Congress and politicians in the establishment of a "Jewish Home" in Palestine ever since Lord Balfour made his declaration in 1917. But no American president, up to and including Franklin D. Roosevelt, had so openly and enthusiastically followed a pro-zionist policy as did President Harry S. Truman. The President's concern for the beleaguered Jews of Europe was, no doubt, a noble one. "But the solution certainly did not lie in the creation of a Jewish state in Palestine," says Muhammed Agwani, "for.. . it could not be effected without inflicting lasting injuries upon the indigenous Arab population."2

The American President disregarded this and other important considerations and constantly succumbed to the pressures of Zionism and to considerations of domestic politics. The President's behavior prompted Walter L. Wright to make the comment that "The President of the United States is supporting the Zionist national interest at the expense of the national interest of the United States." 3 To add insult to injury, the United States handled the situation at the United Nations in a most unusual way. According to Professor H. A. R. Gibb,

1"From the Shores of Tripoli to the 0il Fields of Arabia," p. 21. ${ }^{2}$ Agwani, The United States and the Arab World, p. 131. ${ }^{3}$ Walter Livingston Wright, Jr., "Contradictory Foreign Policies in the Near East," Virginia Quarterly Review, XXIII (March, 1947), 189. 
the methods by which the Near Eastern policy of the United States was forced through the Assembly of the United Nations in 1947 not only undermined at one stroke, through much of Europe and all of Asia, the authority of the United Nations, but also undermined respect for the integrity of the United States in its dealings with the United Nations.

The fact that the United States clearly and unreservedly sided with Zionism and Israel against the legitimate rights of the Palestinian Arabs for self-determination and justice was bound to inflict lasting injuries upon the Arabs in general. Therefore, in the circumstances of the post-War era, America's pro-Zionist policy "could hardly be called a discreet foreign policy of a nation who had assumed colossal responsibilities toward international society."2

The growing Euro-American cooperation during the Truman years had a profound impact on America's relations with the Middle East. American officials very carefully avoided following a policy that might have caused them to clash with the interests and policies of either Great Britain or France. The United States, under President Truman, took the position of a benevolent observer in the protracted Anglo-Egyptian negotiations over Suez, and supported the British view that the Importance of Suez made it unthinkable to dispose of it, and that Egyptian sovereignty was not in any way compromised by the presence of British forces there. ${ }^{3}$

${ }^{1}$ Hamilton Alexander Rosskeen Gibb, "Introductory," in Richard Ne1son Frye, ed., The Near East and the Great Powers (Cambridge, Mas8.: I strard University Press, 1951), p. 10.

2Agwani, The United States and the Arab Wor $1 \mathrm{~d}, \mathrm{p} .13 \mathrm{z}$. p. 18 .

3"From the Shores of Tripoli to the 011 Fields of Axabia," 
In her cooperation with colonial powers such as Britain and France, the United States displayed an increasing lack of enthusiasm for the princlple of "self-determination" of peoples and their "sovereign rights," which she had championed for so long. Instead, nationalist movements were viewed with distrust and caution. The global considerations of the "containment" policy overrode the interests of nationalist movements. Promoting British interests in the Middle East was political sulcide for American policy in the area. American statesmen overlooked the fact that the surest guarantee against Russian intrusions was the cultivation of Arab friendship and goodw111 through genuine and honest support of thefr national aspirations. There was no way to win the Arabs through American support of British-French colonialism and polftical zionism. "The tragic irony of the situation as far as American diplomacy is concerned," says Fayez A. Sayegh,

is that, in order to promote the cause of freedom in the world at large, the United States has allowed itself to become an accomplice, or at least to condone the struggle of colonial powers against the attainment of national freedom by those nations now under their total or partial domination. ${ }^{1}$

As a result of this trend in American policy, it became increasingly difficult for the Arabs, as well as the whole Asiatic and African peoples, to make the distinction between the pollcies of the "imperialist" powers and those of the United States.

${ }^{1}$ Fayez A. Sayegh, "The Arab Reaction to American Policy," Soclal Science, XXVII (October, 1952), 190-91. 
PART II. CONTAINMENT: THE DULLES ERA

CHAPTER IV

THE BAGHDAD PACT

By the end of 1952, the NATO alliance had been erected and Greece and Turkey had been drawn to it. But the southern flank of NATO, the region between the Mediterranean and the Gulf, remained open. American policy planners thought it essential to have it covered by some kind of a defense arrangement capable of protecting it against the Soviet Union, guarding its resources, and keeping its communication routes safe. When John Foster Dulles took over as Secretary of State early in 1953, he began to put into effect a policy that, on the cold war issue, was basically not different from that followed by Truman and Acheson except in its vigor. Secretary Dulles sought to continue the encirclement of the Soviet Union with Western defense pacts and alliances depending on America's superiority in armaments. 1

\section{DULLES MEETS NASSER}

The Secretary of State paid a visit to the Middle East in the spring of 1953. His first stop was Egypt. Mohammed H. Haykal says that the objectives of his visit were, (1) "to proceed to complete the encirclement of the Soviet Union with political and military alliances--

${ }^{1}$ Campbe11, Defense of the Middle East, pp. 49-50. 
an objective in which he was so engrossed as to appear hysterical and from which, in effect, sprang all his actions in regard to the Middle East," and (2) "to feel the possibility of effecting a settlement between the Arab states and Israel."I The first objective, no doubt, was Dulles's main concern. He wanted to sell Nasser the idea of collective Middle East defense. One of Nasser's first questions was, "Defense against whom?" When Dulles said that it was to be against the Soviet Union, Nasser pointed out that there was a distance of about five thousand miles separating the Soviet Union from Egypt and that the Soviet Union never attacked Egypt at any time in history. The only enemy Nasser feared then was Great Britain, whose forces were still in Egypt.2

Nasser patiently explained to Dulles his views on the problem of Middle East defense. Excerpts of what Nasser said in Dulles's presence are included here because of their importance to the understanding of the failures of "containment" in the Middle East and the subsequent deterioration of American-Egyptian relations. Nasser thought it absurd for the United States to ignore British occupation of Egypt and ask her to join a Western-sponsored alliance directed against an enemy of the West that was five thousand miles away. "People in Egypt are smart," Nasser told Dulles,

1a1-Ah-am (Cairo), September 17, 1971. References to al-Ahram, September 17 and 24 and October 15, 1971, refer to parts of a book about Jamal Abdel Nasser by Mohammad Hasanayn Haykal being published in London.

2Mohammad Hasanayn Haykal, Nahnu . - wa-Amrika (Cairo: Dar a1-'Așr al-Hadith, 1967), p. 77. 
and have behind them thousands of years of clvilization. They would quit trusting me if I tell them that we are going to forget British occupation of Suez that is here and now . . so we may participate in a defense organization against imagined danger from the Soviet Union. 1

Secretary Dulles asked with astonishment, "Don't you see any

Soviet danger?"

Nasser answered,

I like to ask you first, how do you see the Soviet Union coming to us? Wi11 the Red Army try to occupy the whole Middle East to get to us? In our opinion, that is impossible. The Soviet Union cannot do so even if she wanted, because that will trigger a nuclear war. The atom has practically made war impossible. It has become extremely risky for any of the contending world powers to launch a military attack even if it had the capability to do so. That means a nation trying to influence another in our age will choose to subvert its internal front rather than attack its outer frontiers. This is the possibility of war we see--internal subversion directed against the internal front. In our opinion, our participation in Western military alliances or in any foreign power alliances does not strengthen our internal front but weakens 1t. The only guarantee against subversion is nationa1ism, the people's faith in freedom, and the realization that it is within their grasp. It is very easy for me to sign with you an agreement to join a pact meant to defend the Middle East. My signature will bind me, but it will not bind the Egyptian people. They will definitely refuse to be bound by it, and they wil1, no doubt, reject me. The result will be an estrangement of the people and a feeling on their part that their government does not represent them. Such a situation would provide the most suitable circumstances for an assault against the internal front. How do you propose to deal with this kind of subversion through military bases when numerous secret bases would be erected to work against you in our country and to paralyze, when necessary, any usefulness of your pacts and alliances? ${ }^{2}$

$1_{\text {Ibid., p. } 78 .}$

2Ibid., pp. 78-80. 


\section{THE "NORTHERN TIER"}

Though Dulles believed Nasser spoke with conviction, it was not what he wanted to hear. Moreover, he did not believe that Nasser could pose a serious threat to his plans for Middle East defense. Opon his return to Washington, Secretary Dulles reported,

A Middle East Defense Organization is a future rather than an immediate possibility. Many of the Arab League countries are so engrossed with their quarrels with Israel or with Great Britain or France that they pay little heed to the menace of Soviet Communism. However, there is more concern where the Soviet Union is near. In general the northern tier of nations shows awareness of the danger. 1

This was the origin of the "northern tier" concept of defense, which was later replaced by the Baghdad Pact. Dulles acknowledged that a regional defense system must spring from the desires of the peoples and govermments of the area "out of a sense of common destiny and common danger." 2

Nasser's attempt to point out that internal subversion was the grave communist danger in the Arab world and that the most effective way to fight it was through social reform and satisfied nationalism, constituted a sound assessment of the situation. Dulles's preoccupation with bases, pacts and power strategy, however, prevented him from giving proper weight to Nasser's considerations. Instead, the plan for a "northern tier" alliance emerged soon after, and Dulles adopted an attitude of intolerance toward neutralists. To him neutralism was "Immoral" and "short-sighted." He believed that a "northern tier"

1John Foster Dulles, "Report on the Near East," U.S., Department of State, Bu11 in, XVIII (June 15, 1953), 835.

2 Ibid. 
alliance would block Soviet attempts to penetrate the Middle East. Dulles assumed that the danger posed by the Soviet Union was mainly military. The possibility of suiversion or other means was secondary. 1 According to M. A. Fitzsimons, a pact "was not a necessary development of the containment policy, for strength might have been better promoted by other measures. But at this time military considerations were very influential in American policy." 2

In the spring of 1953, the United States gave Pakistan 700,000 tons of wheat to help relieve her food shortage. As a result the Onited States became very popular with the Pakistanis. When Secretary Dulles visited Pakistan that spring, he was given a very warm welcome. In early November 1953, it was reported that defense talks were to begin soon between Pakistan and the United States. ${ }^{3}$ On February 2, 1954, President Eisenhower approved a request for military assistance to Pakistan and, during March and April, a United States military mission surveyed Pakistan's arms needs. On May 19, the United States signed a military assistance pact with Pakistan. During March, King Faysal II of Iraq paid a visit to Pakistan and spoke of closer relations between the two nations. Upon his return to Baghdad, the King and his Prime Minister, Fadhil al-Jamali, expressed the view that the new alliance would be beneficial for Iraq. On April 2, a TurkishPakistani Pact was signed in Karachi and, in mid-June, an agreement

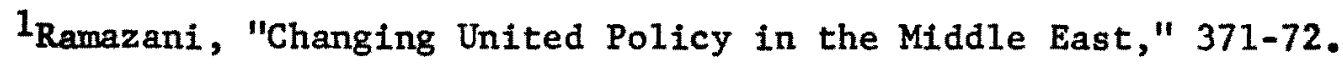

2M. A. Fitzsimons, "Suez Crisis and the Containment Policy," Review of Politics, XIX (October, 1957), 434.

3New York Times, November 2, 1953. 
on the methods of its implementation was reached in Ankara between the two countries. By then the al-Jamali government had fallen mainly because of strong popular opposition to the Pact. Nevertheless, four days following its fall (on April 21) the United States agreed to grant Iraq military assistance and an American military mission followed to assess the military needs of Iraq. ${ }^{1}$

Both India and Afghanistan voiced their objections to these developments. In Iran, however, where the United States significantly increased her military assistance after the fall of Mossadegh, the Turkish-Pakistani Pact was welcomed by the government of Reza Shah. Egypt, whose foreign policy had been reviewed by her foreign service officials in a series of meetings lasting from December 1953 to the end of February 1955, strongly opposed the Pact. Her opposition was in harmony with her foreign policy, which was set during those meetings. It stressed the need to establish "an Arab bloc, free from imperialist influence, to protect the interests of Islamic, Astatic and African peoples." Neutrality was highlighted in those meetings. Egypt's neutrality meant seeking complete national independence and insisted on the sort of cooperation which gave full recognition of Egypt's rights, national sovereignty and prestige. On February 10, 1954, Major Salah Salim declared Egypt's determination to oppose and refuse to

co-operate in any way whatsoever with anyone who opposes our dignity and freedom. We will co-operate with and support all

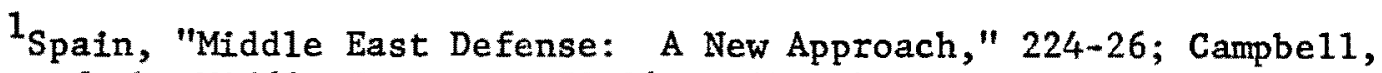
Defense of the Middle East, Pp. 50-54; Po1k, The United States and the Arab World, P. 271. 
who assist and support us. . - We will not discriminate between one state and another, except in the measure of its response to our demands and its support of us in the economic and political fields, which respect our Egyptian nationality; we will not tag along behind anyone. 1

A similar view was expressed in Syria on March 4, three days after the overthrow of Adib al-Shishakli. The new Prime Minister, Sabri al-Asali, warned against the broader implications of the Pact. He declared, "no Arab state can take a decision concerning it until it has been approved by the Arab League in accordance with the provisions of its charter." 2 In the same month, the Egyptian government Informed Jefferson Caffery, the American Ambassador in Cairo, that Egypt would, "by every means," resist any attempt to include Iraq in the contemplated Pakistan-Turkey alliance because it tended "to weaken Egypt and her cause."3 When the Arab League Council met in Apri1, member states resolved not to "accept any responsibility undermining their responsibilities as members of the Arab League." 4

This American diplomatic activity was the result of the shift In Washington from the concept of defense based on Suez to the multi-lateral concept of the "northern tier." The initiative had been Washington's. Britain took no part in those negotiations and British statesmen could not hide their resentment of those American

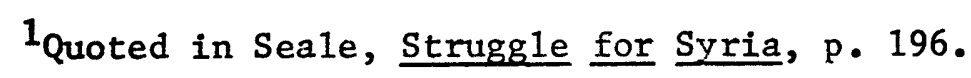

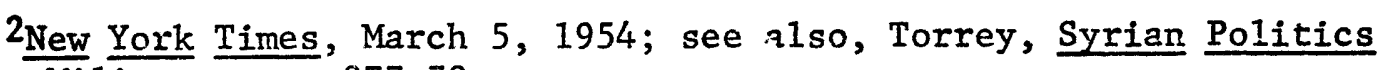
and the Military, pp. 277-78.

${ }^{3}$ Times (London), March 23, 1954, quoted in Spain, "Middle East Defense: A New Approach," 258.

${ }^{4}$ New York Times, April 2, 1954. 
incursions into what was considered Britain's sphere of influence. ${ }^{1}$ Although the two powers agreed in principle on the need to defend the Middle East, they disagreed is to how defense should be implemented. Britain was still concerned over her dwindling position in the area and was desperately trying to salvage what she could of it. To do so, she fought for the retention of her existing treaty rights and military facilities with certain states of the Middle East. A Westernsponsored system of defense, the British thought, would help toward that end. But the United States had little respect for those British objectives. Washington was mainly concerned over the area's defense against Russia, and felt that British tactics were keeping the Arabs from cooperating.

Though this difference was not very pronounced before 1952, it came to be clearly seen by 1954. During the Anglo-Egyptian negotiations over the evacuation of Suez, the British sought a settlement that would be conditional on the agreement by Egypt to join a Middle East defense system. The United States, however, tended to be rather impatient with this British requirement. In fact, the United States often refiected the Egyptian view that it was unreasonable to ask Egypt to join a Western alliance while British troops were still on Egyptian soi1.2 In his memoirs, Anthony Eden says, "It was unfortunate that the United States Government and in particular, their Ambassador in Cairo $\underline{\bar{J}}$ efferson Caffery $\bar{T}$, were not prepared to put

${ }^{1}$ Seale, Struggle for Syria, pp. 189-90.

2Eisenhower, Mandate for Change, pp. 151-59. 
any pressure upon the Egyptians."1 Eden goes on to say that,

Anglo-Amertcan differences about Egyptian policy persisted. In a report home on the year our Ambassador in Cairo commented that American policy in general seemed to be conditioned by a belief that Egypt was still the victim of British "colonialism," and as such deserving of American sympathy. 2

\section{THE FIGHT OVER THE BAGHDAD PACT}

Having been outmaneuvered by the U.S. and having concluded an agreement with Egypt in October, 1954, to evacuate the Suez base, Britain welcomed an initiative, in late 1954, by Nuri a1-Said of Iraq to work "on a plan to strengthen the Arab League Pact, by the Inclusion of Turkey and with the help of the United Kingdom and the United States. 13 As it turned out, however, Nuri's plan only worked to undermine the Arab League and received little, if any, support from other Arab states. In his attempt to present Nuri's defense proposals to the Syrian representative at the United Nations, Eden was told

In terms expressive of much_Arab opinion, then and since. "The people of Syria," he /the Syrian representative/ said, "are by no means opposed to the Anglo-Saxon countries, nor do they have strong anti-Soviet feelings; they have, in fact, very little feeling at all about the Soviet Union. The threat of aggression to them is not from Russia, but from Israel." 4

The Cairo "Voice of the Arabs" bitterly attacked Nuri's plan. Major Salah Salim paid visits to Saudi Arabia, Yemen and Lebanon to

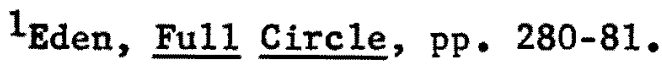

2 Ibid., p. 284.

3Ibid., p. 283.

4 Ibid., p. 252. 
point out the necessity of a unified Arab policy on major issues and the unwsdom of adhering to foreign-inspired military alliances. With Nasser's strong support, Arabism became Egypt's official policy-a policy aimed at achieving unity through non-alignment. Non-alignment was to be the surest guarantee of Arab independence. The points of view of Egyp $\bar{t}$ and Iraq were so different that two meetings between Egyptian and Iraqi officials (one at Sarsank in Iraq during August 1954, and one between Nuri and Nasser in Cairo during September of the same year) could not help resolve Iraqi-Egyptian differences. Faflure to reconcile the points of view of Egypt and Iraq did not hinder Nuri from pursuing his objective of forging an alliance, in which Turkey was to be a partner and, in the achievement of which, the U.S. and Britain were to assist. After visits to London and Ankara, Nuri advanced his plan, according to which Turkey was to move away from Pakistan and brought closer to the Arab states. On January 13, 1955, Nuri al-Said and the Turkish Prime Minister Adnan Menderes Issued in Baghdad a joint statement on the conclusion of a mutual defense pact. On February 24, Turkey and Iraq signed an agreement, since then known as the Baghdad Pact. Soon after, Britain, Iran and Pakistan joined it. ${ }^{1}$

Though the United States supported the Baghdad Pact financially and militarily, joined its committees and has attended its meetings ever since, she had not officially joined it. According to Herman Finer, "Dulles had been intimidated by the ferocious uproar in the

${ }^{1}$ Campbe11, Defense of the Middle East, pp. 52-55; Torrey, Syrian Politics and the Military, pp. 279-82. 
Middle East against Iraq."1 The explanation given by the State Department was that the United States wished to avoid offending Nasser, K1-g Saud, Israel or pro-Israeli elements. "No one was fooled, however," says Richard No1te, "and the U.S. has been roundly criticized both by opponents of the Pact for supporting it and proponents for not supporting it fully and openly."2

On January 22, 1955, upon the invitation of Egypt, Arab premiers met in Cairo to censure Iraq for her policy. Although Nuri did not attend the meeting, the participants did not issue a statement of censure. There was, however, general disapproval of Iraq's policy. The government of Premier Faris a1-Khoury of Syria fell on February 7 due, in part, to the Premier's unwillingness to censure Iraq during the Arab Premiers Conference in Cairo (January 22 to February 6, 1955). On February 13, a leftist coalition, dominated by the Ba'th Party, was called upon by the Syrian President to form a cabinet. This was a major victory for Egypt, since Syria was the key to the success or fallure of Egypt's policy, and marked the beginning of the ascendancy of the neutralist left in Syrian politics. ${ }^{3}$

Egypt and the $\mathrm{Ba}^{\prime}$ th were drawn closer together by the similarity of their views on foreign policy. To face the rightist forces in Syria, the Ba'th began edging towards the communists. This Ba'thist-

1Herman Finer, Du1les Over Suez: The Theory and Practice of h1s Diplomacy (Chicago: Quadrangle Books, 1964), p. 18 .

${ }^{2}$ Richard H. No1te, "American Policy in the Middle East," Journal of International Affairs, XIII, No. 2 (1959), 118.

${ }^{3}$ See Torrey, Syrian Politics and the Military, pp. 275-315. 
Egyptian-Communist relationship put Syria on the side of Egypt and made her an object of Soviet interests and hopes. The Foreign Minister in the new cabinet, Khalid al-Azm, reflected on his government's policies in an interview with Patrick Seale in late 1960 . He said,

We felt we needed the support of a group of nations which had no preconcelved notions on the Israeli issue and which could give us their backing at the United Nations.

This wäs the reason we became pro-Russian deriving great moral and material support from the eastern bloc. Our rapproachment with the East continued when I became Foreign Minister after Faris a1-Khuri's downfal1. It was to stand us in good stead at the time of Suez. But it must not be supposed that we became converts to communist ideology. We distinguished between international affairs and internal social and political questions. It was only on the international level that we were prepared to go along with the communists. 1

The Syrian left recelved ful1 support from Egypt. Being in the midst of a circle of pro-West states (Turkey, Iraq, Jordan, Israel and Lebanon), Syria badly needed the support that both Egypt and the Soviet Union gave her.

According to Patrick Seale, the Baghdad Pact "was intended for a dual purpose: as a military weapon against the Soviet Union and as a political instrument of British and Iraqi power in the Arab world."2 Nurf al-Said had helped the British to outmaneuver the Americans. The Baghdad Pact differed from the "northern tier" concept in that it made the Arab world once more the center of gravity for Middle East defense. While Dulles was trying to construct a line of defense against

1al-Azm to Seale, Damascus, November 8, 1960, in Seale, Struggle for Syria, pp. 219-20.

${ }^{2}$ Ibid., p. 186. 
Russia's borders by binding mainly non-Arab states in an alliance, Britain supported Nuri's plan in an effort to harness the Arab Collective Security Pact through Iraqi leadership. On January 11, 1956, Secretary Du1les stated that the U.S. "has been . . sympathetic toward the formation of the Baghdad Pact; indeed it comes out of an idea I developed . . . the 'northern tier' concept."l Herman Finer notes, however, that

At the end of April 1956, the Secretary of State told some Washington correspondents in a private "background" session that the British had "perverted" his idea of a pact which would include only nations facing north, when they brought in Iraq, and in doing so had aroused the hostility of the other Arab nations. ${ }^{2}$

The Egyptian Economic and Political Review tries to show that the Baghdad Pact was nothing less than a British coup that foiled a promlsing Egyptian-American relationship.

Britain, through her ever willing servant Nuri e1-Said ... had frustrated the Egyptian intention to strengthen the Arab Collective Pact. The angry Egyptian reaction and Egypt's determined stand for Arab unity against the Baghdad alignment, placed a worried American State Department in the dilemma of having to choose between a promising new relationship with Egypt, and loyalty to an alignment America had done much to sponsor, and which $i$ tself was associated with her European allied via N.A.T.0. ${ }^{3}$

Advice from American foreign service personnel in the Middle East was generally opposed to the idea of the Baghdad Pact. But none could possibly "shake the views of Washington policy makers at that

1 U.S., Department of State, American Foreign Policy, Current Documents, 1956 (Washington, D.C.: Government Printing Office, 1959), p. 561.

${ }^{2}$ Finer, Dulles Over Suez, p. 18.

3"Isolation or Entanglement," p. 16. 
time," says Miles Copeland,

Here were gentlemen who saw world affairs in the perspective of the atom bomb, the East-West cold war, NATO and the Warsaw Pact; their thinking about the Middle East was in terms of its economic problems and resources--apart from the question of Israel, that is, which, for reasons of domestic politics in the United States, demanded an awareness out of all proportion to its strategic importance. 1

There was and will, perhaps, always be a "'field perspective'", says Copeland, and a "'Washington perspective,' and except for brief lightning flashes every now and then, the two remain utterly incommunicable."2

There was grave doubt that the Baghdad Pact could make any progress in winning the popular support of the Arab masses. ${ }^{3}$

Nevertheless, Arab governments were vulnerable to it. According to Patrick Seale, "Syria enjoyed what amounted to a casting vote on the Pact's future: had she applied for membership, other Arab states would have followed; in the event, her abstention and hostility 'froze' the alliance, isolating its only Arab member, Iraq." 4 But the very fact that Iraq began receiving Western arms could have enabled her to build a military might and expose the relative impotence of Egypt's power. Besides, Iraq's joining the Pact could make of her a formidable opponent of Egypt. Nuri might revive the "Fertile Crescent" scheme

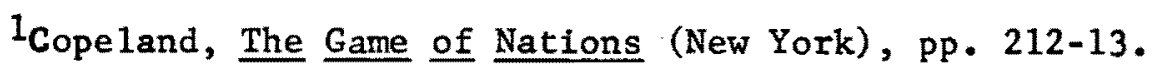

2 Ibid., p. 213.

3Paul Hanna, "America in the Middle East," Middle Eastern Affairs, X (May, 1959), 188.

${ }^{4}$ Seale, Struggle for Syria, p. 213. 
and undermine the whole idea of a pan-Arab movement and exclude Egypt.

This was completely unacceptable to Nasser and the progressive movement of Arab nationalism. Nuri was attacked by both Cairo and Damascus radios and labeled as traitor to the Arab cause of nationalist unity. "Nasser also intensified the ideological campaign against Zionism," saỳs James Dougherty, "in order to highlight the artificiality of any anti-communist pact which relegated to a subordinate place the 'real threat' to the Arabs, namely, Israel."1 Egyptian and Syrian officials paid visits to Jordan, Saudi Arabia and Lebanon to try and achleve some sort of Arab unity and cooperation in foreign policy, in military, cultural and economic affairs. Saudi Arabia promptly supported the Syrian-Egyptian initiative; Lebanon and Jordan wanted to take their time.

Nuri's challenge was countered, partly through the SyrianEgyptian-Saudi alliance. The Baghdad Pact was already a lost cause, for when England joined it, no hope remained of winning any Arab state to 1t. "Most Arabs were convinced," says Senator Humphrey,

that the charges of Radio Cairo were really true . . that the Pact was . . a backhanded way of perpetuating old imperialist interests and keeping the Arab world divided against itself. When the U.S. government in turn established political and military 1iaison with the Pact members in Baghdad, Egypt and its friends saw further confirmation of their suspicions.?

\section{REASONS FOR FAILURE}

The battle over the Baghdad Pact was a battle between the traditional

1Dougherty, "The Aswan Decision in Perspective," 36.

2 Humphrey, "A Chronology of Failure," 12. 
world of Nuri and the new progressive world of Nasser--a battle that Nasser was prepared for and enjoyed tremendous advantages over Nuri. In 1955, Iraq was stil1 backward and its peasants were in debt to their 1ords. According to Harry Hopkins, "the entire cultivated area was owned by only 4 per cent of the population."1 The Development Board, established in 1950 to use 75 percent of Iraq's oil revenue on public works projects, had not proved its effectiveness. When in 1952 , Egypt announced her land reform program, riots broke out among Iraq's poor sharecroppers. The Baghdad Pact, under these circumstances, was viewed by "politically conscious Arabs everywhere," says Hopkins, as "a Holy Alliance designed to repress the gathering Arab Revolution and to maintain that fatal old status quo in which Arab feudalism made common cause with Western Imperialism."2

One can only conclude that the Baghdad Pact was advanced without careful consideration of its possible impact on the peoples concerned. It Inflamed Egypt and aroused her opposition, and British participation made it completely unacceptable to the Arabs. The fact that it was proposed through Turkey and Iraq, the former a recent imperial power In the Middle East and the latter sti11 a puppet under British influence, foredoomed it. It bypassed the Arab League and undermined the concept of Arab unity. It presupposed an enemy that the Arabs did not fear and ignored the sne they did fear. Iraq's politicians may have been drawn to it becase of a feeling of proximity to Russia, or because of

1Hopkins, Egypt, the Crucible, p. 163.

2Ibid., pp . 166-67. 
the Soviet-oriented Kurdish minority in Iraq's north. Those may have been the feelings of pro-West politicians in Iraq, but in reality Iraq does not boyder on Russia and is essentially "in and of the Arab vor1d." A major factor, no doubt, was the influence of such Anglophlie polftlelans as Nurf al-Sald and their wish to preserve a BritishIreqi friendihip under terms of equality after getting rid of unequal treaty arrangements. Britain sponsored the Pact because she put Ireq before Egypt, whose sin was that she did not cooperate with her. Britein was a lso bound to the Iraqi royal house and to Nuri by a longtending frlendship. 2 Besides, the Baghdad Pact provided Britain with miltary advantages and substitute for the Saadabad Pact and the Anglo-Iraqi treaty due to expire in $1957 .{ }^{3}$

The negleet of Arab public opinion and the Hest's insensitivity to the forces of nationalism and neutrality were serious blunders. Those forces received a tremendous boost at the Bandung Conference, et which the nations of the Third World "proclaimed that the peoples of their two continents were resolved to put an end to the disgraceful colonlal yoke and ellminate its pernicious aftermath." 4 Nasser's polleles had already been supported by President Tito of Yugoslavia

ICampbe11, The Middle East in the Muted Cold War, p. 445. ZEden, Full Circle, pp. 245-46.

3Castieberry, "The Arabs' View of Postwa: American Foreign Polley," 14-16; Fitzsimons, "Suez Crisis and t:e Containment Policy," 434; Seale, Struggle for Syria, p. 228; Campbe11, The Middle East in the Muted Cold War, p. 445; George Lenczowski, Russia and the West in Iran, 1918-1948 (Ithaca, N.Y.: Cornell University Press, 1949), pp. 305-306n.

${ }^{4} G$. Titov, "The Eisenhower Doctrine and the Peoples of the East," International Affairs (Moscow: May, 1958), p. 41. 
and Prime Minister Nehru of India. While Russia welcomed neutralism as an ally, the West denounced it as "immoral." The Soviets saw In It a means of foiling Western defense plans--hence their support of the Bandung Conference. On this issue both Cairo and Moscow agreed; both saw Syria as the key to the success of a neutralist policy in the Arab worid, and they both supported that country's stand against the Baghdad Pact. When Syria's purchase of German Mark IV tanks from Czechoslovakia in 1954 drew threats and protests from Iraq and Turkey, the Soviet Union stood firm on Syria's side. 1 Syria continued to enjoy Soviet support.

In a published interview with $\underline{\mathrm{U}}$. $\underline{\mathrm{S}}$. News in the summer of 1954 , Nasser asserted that any alliance with the U. S. or Britain would give cause to the communists to exploit it for their own advantage and would enable them to make the accusation that the West has returned to its policy of exploitation and that defense pacts and plans serve only Western aims. Such schemes, Nasser argued, would backfire and prove disasterous to both the Arabs and the West. "It is also a matter of psychology," said Nasser, "you must deal with this area from the psychological point of view--not with agreements, treaties, etc."2 It is unfortunate that his ideas were not given more serious considerations by the West.

The West assumed that the Soviet Union was not about to se11

1seale, Struggle for Syria, pp. 233-36.

"What Should the U. S. Do in the Middle East? Interview with Egypt's Prime Minister Lieut. Col. Gamal Abdel Nasser," U. S. News \& World Report (September 3, 1954), p. 29. 
"modern anms to non-Communist nations in the Middle East, and that even if $i t$ did, there would be no Middle East takers. The formation of the Baghöad Pact," contends J. C. Hurewitz, "gave Russia its opportunity to prove the Western assumptions wrong."1 Washington did not realize that the Arab states could not be forced into an alliance against the Soviet Union. According to Nasrotallah Fatemi, Dulles's efforts were "tantamount to construcing a skyscraper on the sands of the Arabian desert."2 The Baghdad Pact gave Russia the chance to leapfrog into the heart of the Middle East not as a conqueror, but as a welcome guest, and to confront the West in a region that, up to 1955, was considered part of the West's sphere of influence.

The only Arab country that was drawn to the Baghdad Pact could not be held in a state of unnatural isolation from her sister states in the Arab world. It was evident that Iraq would eventually respond to the stronger pull of the Arab world. Therefore, Western relations with Iraq depended largely on the success or failure of the West to find a sound basis for a mutually advantageous relationship with the rest of the Arab Middle East. In the event the West could not find a basis for common interests with the Arab world, Iraq's association with the West became "too great a burden for Iraq to carry." 3 This seems to

1Jacob Coleman Hurewitz, ed., "Soviet-American Rivalry in the Middle East," Academy of Political Science Proceedings, XXIX (March, 1969), 9.

${ }^{2}$ Nasrotallah S. Fatemi, "The Present Crisis in the Middle East," In Samuel Merlin, ed., The Big pwers and the Present Crisis in the Middle East: A Colloquium (Ru- Erford: Fairleigh Dickenson Unirstsity $\overline{\text { Press, }} \overline{1968)}, \bar{p} .36$.

${ }^{3}$ Campbe11, The Middle East in the Muted Cold War, p. 445. 
have been the great obstacle in the way for successful U. S.-Mideast relations. There had to be mutual advantages and common interests. In tead of seeking those common interests, each side tried to convince the other that his way was right. The continued American disregard for Arab nationalist aims and aspirations; the American insistence on involving the Arab world in the cold war; U. S. support of rival nationalisms (Zionism and regional nationalisms); and the continuing American association with colonial allies made it impossible for the Arabs to cooperate. "To the extent that common interests have been found with the states directly bordering on the Soviet Union," says J. C. Campbe11,

the northern tier concept had merit. Unfortunately the Baghdad Pact was by no means the best way to bring the concept to concrete realization. Leaving aside the question whether its formation provoked the Soviet jump into the "southern tier", the failure of the West to find a basis of common interest with the Arab States other than Iraq is what brought on the grave crisis that began with the Soviet-Egyptian arms deal and has deepened ever since. 1

Nasser's campaign against the Baghdad Pact succeeded. Its success dramatically demonstrated that Nasser was only expressing what most Arabs felt and wanted. His victory made him the uncontested leader of the progressive Arab movement, and his alleged intrigues against pro-West Arab governments became a major cause for the deterioration of American-Egyptian relations. He was blamed for almost a11 that took place in the Arab world since, and was often accused of plotting to overthrow the friends of the West. Nasser in his turn believed that

$$
\text { I Ibid., p. } 446 .
$$


the U. S. and Britain were inciting opposition to him through such pro-Western politicians as Nuri al-Said of Iraq, King Hussein of Jordan and President Chamoun of Lebanon. He was always fearful of an American CIA-inspired coup to topple him or to install a pro-Western regime in Syria. He could recall very well how Dr. Mossadegh fell in Iran in 1953. As suspicions mounted on both sides, confidence was lost and cooperation seemed further than ever. On his part, Nasser explained that his only means of reaching the Arab people was the "Voice of the Arabs" and that nationalist activity in the Arab world was inspired and prompted by legitimate local aims, desires, hopes, fears and aspirations. ${ }^{1}$

${ }^{1}$ E11is, Challenge in the Middle East, Pp. 37-40. 


\section{CHAPTER V}

\section{THE RUSSIAN ARMS DEAL}

The United States looked with favor upon the July Revolution of 1952 in Egypt, in which King Farouk was outsed and a group of military officers assumed power. Washington was hoping Egypt would become the cornerstone of United States foreign policy in the Middle East. Egypt's revolutionary officers were busily trying to cope with Egypt's internal problems and General Neguib seemed moderate and cooperative. In late 1952, Henry Byroade, then Assistant Secretary of State, declared,

The policy goals and actual accomplishments of the new regime in Egypt are such as to deserve our full support. . . We believe that this regime deserves the support of the Western powers. We should all be ready to assist where possible in helping it attain its proclaimed goals for the future.

American sympathy with the officers' aims had been unofficially expressed before the Revolution took place in July 1952. American CIA agents became aware of the officers' plans to overthrow the Farouk regime as early as March 1952. However, Colone1 Gama1 Abde1 Nasser, the officers' guiding spirit, showed coolness toward their approaches. He was aware of the fact that, for it to be genuine and to succeed, his revolution had to be purely Egyptian in nature and free from foreign interference. The new regime, he believed, had to have a free hand in making decisions and moves that were solely for

${ }^{1}$ Henry A. Byroade, "U. S. Foreign Policy in the Middle East," U. S., Department of State, Bulletin, XXVII (December 15, 1952), 934. 
Egypt's good, regardless of Great Power interests. These were corvictions which constituted the basis of his later policy of "positive nestrality"--a policy that had other exponents such as Akram al-Hourani and the $\mathrm{Ba}$ 'th leaders in Syria, who had advocated it long before the Egyptian officers came to power. This policy was stated and restated repeatedly in various ways and forms to both Western and Soviet governments when Nasser felt an attempt was being made to influence him. 1

Despite his apparent coolness toward American approaches and despite his obvious nationalistic and independent stance, Nasser still could count on American support and backing. He enjoyed the friendship of a number of Americans in Egypt. American Ambassadors such as Caffery and Byroade were his friends. Among his other American friends were William Lakeland, the political officer at the American Embassy in Cairo, Kermit Rooseve1t and Miles Copeland, who were CIA men. These and other friendships among American private citizens, engaged in various enterprises in Egypt, provided a rare opportunity for Americans to exchange views with an outstanding Middle Eastern leader in a key Middle Eastern state. 2

According to M. H. Hayka1, a confidant of Nasser and editor of a1-Ahram newspaper, the opportunity was there for Egypt and the United States to cooperate. He gives the following reasons why cooperation was possible: (1) Britain was the main enemy and the dominant Egyptian concern was to force her out; (2) The United States, among the Great

1E11is, Challenge in the Middle East, pp. 35-36; Copeland, The Game of Nations (New York), pp. $\frac{15-72}{148}$.

2E11is, Cha1lenge in the Middle East, pp. 35-36. 
Powers, was the most acceptable because of her clean war record, her economic strength, her four freedoms, her lack of colonial history in the area; (3) The Soviet Union wes far, unattractive under Stalin, and appeared to be preoccupied with European problems; (4) Though the United States was one of the main supporters of the creation of the state of Israel, it was Britain that received most of the blame because it was she who issued the Balfour Declaration and under her mandate Zionism prospered; (5) Before the Baghdad Pact, the United States was still in the fog and, therefore, could choose what to do before a verdict was passed on her. Haykal goes on to say that on the morning of July 23, 1952, the day of the Revolution, the officers made their first diplomatic contact with Mr. Jefferson Caffery, the American Ambassador. A representative was sent to inform him of the fall of the Farouk regime and of the aims and objectives of their Revolution, which indicates that the new Egyptian regime was anxious to establish good relations with the United States. 1

\section{THE REPUBLICAN ADMINISTRATION'S "NEW OUTLOOK"}

When the Republican Administration took over in early 1953, a "new outlook" in foreign policy was announced. 2 Greater understanding of Asiatic and African peoples was sought in an effort to develop a policy that would help win them as friends and allies. ${ }^{3}$ The obvious

1Mohammad Hasanayn Hayka1, Nahnu . - wa-Amrika, Pp. 55-58; see also, Copeland, The Game of Nations (New York), Pp. 74-75.

${ }^{2}$ Campbe11, Defense of the Middle East, p. 49.

3"From the Shores of Tripoli to the Oil Fields of Arabia," p. 16. 
lack of success on the part of the Truman Administration to win Arab friendship prompted the Eisenhower-Dulles Administration to work on re-toring Arab confidence and goodwil1. On March 12, 1953, President Eisenhower assured Prince Faisal of Saudi Arabia that his Administration "was determined to restore the spirit of confidence and trust which had previously existed between the United States and the Arab nations."1

From 1953 to 1956, the Eisenhower administration tried to forge a new relationship with the Arab world. An attempt was underway to tone down the previous Administration's pronounced support for Israel and to, as much as possible, free U.S. policy from the stigma of ful1fledged cooperation with Britain and France in the Middle East. The Idea was that, for U. S. policy to succeed, the U. S, was to disassociate herself from English and French colonialism in the region and to assume an impartial role in the Arab-Israeli dispute. Once this policy proved successful and Arab friendship was won, they then would be encouraged to build their own system of defense against Communist Russia.

Following Dulles's visit to the area in 1953, Washington concluded that the idea of a broad defense system was unrealistic and that it should be substituted by an alliance between those countries ready and willing to join it. Washington also concluded that the irritating disputes, between Britain on one side and Egypt and Iran on the other, should be settled because they were keeping the Arabs and the Iranians from cooperating with the West. But as long as the United States

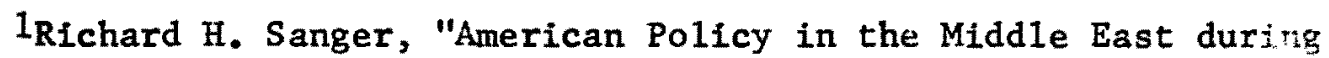
1953," U.S., Department of State, Bulletin, XXX (February 8, $1954^{\circ} 209$. 
sought alliances to include the Arabs, to maintain positions of influence earlier assumed by Britain and France, and to support pro-West reactionary regimes in the area, it was useless to expect either Nassar, the Ba'th Party, or other Arab nationalists to cooperate. The United States persisted in seeking these objectives and her persistence eventually drove the Arabs to seek Russia's assistance. 1

America's new profession of policy met with Great Britain's hostility. While the United States saw in the dynamic and progressive Egyptian regime a new element and a possible chance for an EgyptianIsraeli peace and, perhaps, a defense system, Britain saw in it a new danger to her interests. "So seriously did Whitehal1 look upon the American support of the Egyptian Revolutionary Government," says the Esyptian Economic and Political Review,

that on Mr. Churchill's and Eden's visit to Washington in the spring of 1953 the British government sought American assurances that the United States would not follow independent policies in Cairo without consultation with their British allies. 2

Meanwhile, formal and informal contacts continued between Nasser and American personnel. Nasser was confident that Egypt could deal with the United States on an independent basis. He, therefore, turned to the United States for his first request of economic aid. His aim continued to be complete Egyptian independence and an ability to make political decisions with Egypt's interest in mind. He saw no basic reason why the United States might not fully support such a policy or

1Campbe11, "America and the Middle East," 143-45.

2"Isolation or Entanglement," p. 15. 
why the U. S. and Egypt should not cooperate. Harry Elis contends that "when Secretary of State John Foster Dulles was asking nations to 'stand up and be counted' on the issue of communism, Nasser could not believe this meant the U. S. would give Egypt economic aid only if Nasser joined what he regarded essentially as a foreign effort against a foreign enemy." 1

Nevertheless, in harmony with its "new outlook" policy, the U. S. Government applied pressure on Britain to evacuate Suez. At the same time, American economic aid was withheld from Egypt until an agreement was reached with Britain. ${ }^{2}$ Britain held out until 1954 in the hope that Egypt would join a Western-sponsored defense system before the lease on the Suez Base expired. Under such a system, her troops, Britain hoped, could stay in Egypt. But the Egyptians made it perfectly clear that they would not tolerate British presence any longer under any circumstances. Both sides, therefore, were pressed by the U. S. to reach an agreement. In October 1954, an Anglo-Egyptian agreement settled the matter. Britain agreed to evacuate the Canal Zone by June 19, 1956. Egypt conceded to maintain the base installations and agreed to a short-term legal guarantee of Britain's right to reoccupy it in case of an attack against a Middle Eastern country. ${ }^{3}$

The victory for Egypt was less than total and the Egyptian Government did not escape public criticism. The concession made to

${ }^{1}$ E11is, Cha1lenge in the Middle East, p. 37.

2Robert Strausz-Hupe, Alvin J. Cottre11, and James E. Dougherty, eds., American-Asian Tensions (New York: Praeger, 1956), pp. 81-83.

Middle East Journal, VIII (Winter, 1954), 460. 
Britain was criticized by the Muslim Brothers. But in general the Arab world considered the agreement a significant achievement and a cause for joy and hope. The sterner tone of the United States Government toward the state of Israel took the form of occasional censure through the United Nations of her war-1ike policy, gradual reduction of official $\overline{\dot{U}}$. S. Government aid to her, and refusal of her requests for U. S. arms. ${ }^{1}$ Between 1948 and 1954, Israel received more than four tImes in U. S. Govermment aid than all the Arab states combined. Impartiality was the professed U. S. policy. Assistant Secretary of State Henry A. Byroade declared, "a pro-Israe1i, or pro-Arab policy, has no place in our thinking. The United States must consider with great care the implications of throwing whatever influence we may have in such situation to one side or the other." 2

\section{PERSISTING IRRITATIONS}

By 1953, the Soviet Union began to make certain gestures indicative of a basic change in her policy. Soviet officlals began visits in Asia and Africa, and tensions with Turkey and Iran were relaxed. The dominant Soviet theme was the support of "national liberation movements." Arab nationalism and neutralism began to be seen by the Soviets as a combination of forces capable of driving the West out of

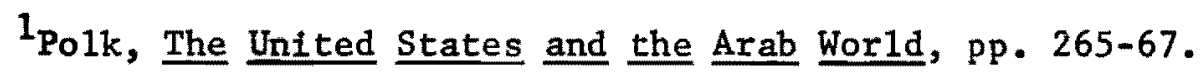

2Byroade, "Th. Middle East in New Perspective," 632. 
the area and opening it for Soviet penetration. ${ }^{1}$ To Nasser and Arab nationalists, this was an excellent chance to relieve them of complete reilance on the West. Nasser's basic aim was to enable himself to secure Western economic and military aid without giving up the objective of Arab world leadership and without having to subscribe to any of the West's strategic defense plans. When the West made the achievement of these aims impossible, Nasser began to display an ability to obtain aid from the East and to seriously endanger Western interests in the region. ${ }^{2}$

The new Soviet approach caused the U.S, and the West greater alarm, and U. S. policy was further stiffened. America's concern over the Middle East was explained in the spring of 1954 by Mr. Henry Byroade.

To understand our concern over developments in this part of the world, it is necessary to understand that we do see an increasing danger that the Middle East may be relegated to a satellite status under the Soviet Union. Most people in the Middle East who read this statement will label it as "alarmist" and without foundation of fact. The very fact that this reaction will exist is partly the cause of our concern. ${ }^{3}$

It is this difference in opinion between the West and the Arab world that was the main cause of difficulty and the reason for the drift

$1_{\text {Geoffrey Wheeler, "Russia and the Middle East," Political }}$ Quarter1y, XXVIII (Apri1, 1957), pp. 134-35; Walter Z. Laqueur, The Struggle for the Middle East: The Soviet Union and the Middle East, 1958-68 (London: Routledge \& $\mathrm{k}$. Paul, 1969), p. 9; Idem, The Soviet Union and the Middle East (New York: Praeger, 1959), pp. 211-13.

'Kerr, "'Coming to Terms with Nasser'," 71.

3 Henry A. Byroade, "Facing Realities in the Arab-Israel Dispute," D.S., Department of State, Bu1letin, XXX (May 10, 1954) 709. 
toward the Soviet Union. Washington failed to win the Arab world and relations with Egypt remained cool.

What further contributed to the failure was the fact the: Washington's professed policy of disassociation with Britain and France was not earnestly followed. The United States also failed to strike a posture of strict impartiality in the Arab-Israeli sphere. As a resu1t, Washington was not able to convince the Arabs that 1 was capable of detaching itself from London and Paris. France, as a matter of fact, was using American arms in North Africa supplied to her through NATO. Moreover, Israel proved to be a major U. S. interest, and any attempt at impartiality by the $U$. $S$. was regarded by the Arabs as fiction, and any reference to the maintenance of a power balance was taken as a reflection of Washington's excessive concern for the security of the state of Israel.

The Tripartite Declaration of May 1950 was interpreted in this 1ight. The Arabs viewed this agreement among the three powers as equating seventy million Arabs with little over one million Jews. "The Arab nationalists were sure," says James Dougherty, "that, however much the State Department might wish to curry the favor of the Arabs, the United States was irrevocably committed to the support of the Zionist experiment." Neither were they impressed by the reduction of direct U. S, aid to the Jewish state, for they believed West Germany's payments of repatriations to Israel were due to American persuasions. Dougherty concludes,

So far as the Arabs were concerned, the crucial test of Washington's sincerity was the degree to which it was willing to build up the economic and military strength of Israel's 
neighbors. The Egyptians were convinced by Washington's steadfast refusal to furnish them arms that the United States failed this test. 1

\section{EGYPT'S BID FOR ARMS}

Ever since the end of World War II, Egypt tried to acquire arms. Egypt sought arms from the United States, Great Britain, France, the Soviet Union, Sweden, Switzerland, Belgium, Spain, and India. Some arms were obtained but not in the desired quantities. For one reason or another, Egypt's efforts to acquire arms failed. The United States never came out with a clear explanation as to why she withhe1d arms from Egypt. Britain and Sweden refused to supply Egypt with arms as long as Anglo-Egyptian negotiations over the Suez Base were not yet concluded. France's reason was Nasser's support of Algeria's rebels. And according to Khrushchev, Stalin refused to sell King Farouk arms because the Middle East was within Britain's sphere of influence; "therefore, we couldn't go sticking our nose into Egypt's affairs. Not that Stalin wouldn't have liked to move into the Near East--he would have liked to very much--but he realistically recognized that the balance of power wasn't in our favor and that Britain wouldn't have stood for our interference." 2

Nasser's first request for U. S. arms was made in the fall of 1952. Washington did not refuse his request. A prompt American reply

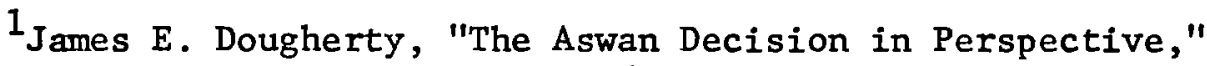
Political Science Quarter1y, LXXIV (March, 1959), 33.

2 Nikita S. Khrushchev, Khrushchev Remembers, with an introduction, commentary and notes by Edward Crankshaw, trans. and ed. by Strobe Talbott (Boston: Little, Brown and Company, 1970), p. 431. 
revealed that there existed a secret agreement between the former goverment of Egypt and the United States. The agreement was signed in February 1951, but was not fuily implenented. In accordance with it, the U. S. was ready to supply Nasser with the arms agreed upon with King Farouk. But the new Egyptian regime did not wish to bind itself by that secret agreement because the type of arms agreed upon was not what the new regime needed. What the Farouk regime contracted to purchase were arms useful for protecting the regime and keeping internal peace. Egypt's new rulers sought the type of arms that would help raise the morale of the army and defend Egypt against external threats. 1

In November 1952, Assistant Secretary of Defense William Foster arrived in Cairo to discuss Egypt's military needs. Nasser submitted to him a list of the military equipment Egypt wanted, which Foster approved after minor modifications. Upon his return to Washington, an Egyptian delegation, headed by Wing Commander Ali Sabri, then Director of Nasser's office as Acting President of the Revolutionary Command Council, was invited to the U. S. to sign the agreement. The delegation arrived in the midst of the presidential elections in the fall of 1952. Sabri's mission, however, was unsuccessful and Nasser requested an explanation from Ambassador Jefferson Caffery, who apparently had no explanation to give. The facts were that Sabri's mission ran into serious difficulty. The nswwer can be found in a conversation between General 0lmstead, then charge of foreign military aid at the Pentagon, and M. H. Haykal in Washington. Haykal reports that General

$1_{\text {Hayka1, Nahnu }}$ - - wa-Amrika, pp . 63-64. 
Olmstead was not sure why Egypt was trying to purchase arms when she could get them free by aiding the United States in solving mutual defense problems. General 01mstead went on to explain that the U.S. could not give arms to Egypt as 1ong as the British thought they would be used against them, or as long as Egypt was trying to defeat Israel when the real enemy was the Soviet Union. It was impossible, concluded General 01mstead, to get congressional approval of such a deal as long as Egypt continued to refuse to join an alliance against a dangerous enemy. 1

When the official explanation finally came from Ambassador Caffery after Sabri returned empty-handed, it stated the same reasons given by General 01mstead, plus a few more details. First, said Caffery, William Foster was not authorized to conclude an agreement; he allowed himself to be carried away and committed himself beyond what he was instructed to do. Second, Washington was still willing to grant part of Egypt's request were it not for a telephone call to President-elect Eisenhower from Prime Minister Churchi11, reminding him that U. S. arms in Egyptian hands could be used to kill England's children, some of whom served under General Eisenhower during the last war. Fina1ly, Caffery made reference to Nasser's latest utterances against Britain, which were viewed as threats to use force against Brltish forces in Egypt. In particular, Caffery mentioned Nasser's Interview with Margaret Higgins, published in the New York Herald Trlbune, and a speech delivered at Shibun al-Koum. In the interview, $1_{\text {Ibid., PP. 67-69. }}$ 
Nasser is supposed to have said that armed resistance would begin if negotiations with Britain did not yield the desired results. In the speech, he said that Britain must leave or be ready to defend her forces in Egypt. 1

\section{THE GHAZZAH RAID OF EARLY 1955}

The problem of arms supply was not the only one facing Egypt's new rulers. They had to cope with domestic problems, both economic and politica1. The burden of facing those problems forced the Israeli issue to the sidelines. Nasser's general policy was to keep tension as low as possible while internal problems were being studied and attempts were being made to solve them. But by ear1y 1955, Nasser could not possibly continue to follow such a policy and hope to stay in power. Several events aggravated the situation and made the supply of arms Nasser's most pressing need. In October 1954, thirteen Egyptian Jews were arrested on charges of planting explosive charges in U. S. and British installations in Egypt to embroil Egypt with those two nations. Their trial ended on January 27, 1955. Two were condemned to death and hanged on January 31 ; two were acquitted; the rest received sentences of hard labor, some for life. They had a fair trial and Nasser reasoned they ought to pay the penalty for their crimes. According to the Christian Science Monitor correspondent Harry E11is, "A French lawyer permitted by Nasser to attend the trial testified

I Ibid., pp. 69-71. 
afterward to its fairness." 1

Israel's answer came in a month's time. In retallation for the trial and for Fidaiyeen raids, Israel staged a massive raid on February 28 against Egyptian positions in the Ghazzah strip, in which thirty-eight ${ }^{2}$ Egyptian soldiers were killed. According to M. H. Hayka1, the Ghazzah raid was intended as a shock and a reminder that Egypt did not possess arms and there was none to protect her. Therefore, her only salvation was through joining the Baghdad Pact. 3

On March 1, Nasser said, in a speech to the Military College cadets, "The raid against Ghazzah is going to be the turning point in the history of the Middle East." 4 Two days 1ater, he told Ambassador Byroade that the danger Egypt feared was real and America must give a no-or-yes answer to Egypt's requests for arms. He also told Byroade that his government had committed a grave error in cutting its defense budget to concentrate on internal reform. "I still believe," continued Nasser,

that our conflict with Israel is one that is mainly dependent on economic and social progress in the long run, but I am now convinced that our defense budget should be increased. I cannot fight Israel with schools, hospitals, and factories. If we build schools, hospitals, and factories without the necessary armed force to protect them, Israel would be able to take possession of what we build any time. That is why

${ }^{1}$ E11is, Challenge in the Middle East, p. 41.

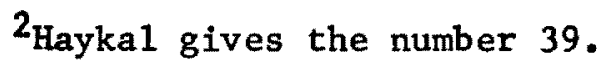

3 Hayka1, Nahnu - - wa-Amrika, p. 92.

${ }^{4}$ Ibid., p. 93. 
we are determined to acquire arms from other sources if you finally decide not to supply us with what we want and need.1

From an Initial request for $\$ 100,000,000$ worth of military equipment, Nasser fina11y settled for about $\$ 20,000,000$. It was evident that the amount requested could not help defeat Israel. That is why American Embassy officials in Cairo favored the sale. They reasoned that Nasser had to improve the morale of his troops and to quiet unrest in his army. But Washington showed no signs of relaxing 1te policy. 2 The Ghazzah raid of winter 1955 was the first serious attack against Egypt since the cease-fire of 1948, and became an open challenge to Egypt's army. Bitter and humiliated, Egyptian army offleer intensified their demand for arms. This raid triggered the arm In Egypt and set the stage for an end to a frustrated and longdelayed bid by Egypt for American arms. The Egyptians believed that the U. S. was delaying and setting impossible conditions in an effort to foresta11 any arms agreement. But Nasser could not stand the deley, and the restraint he had shown toward Israel up to 1955 could not have been continued without permanent damage to his regime's position and standing in the eyes of the Egyptian army, the Egyptian people, and the Arab world.

General Eedson Burns, the United Nations military representative In the area, testified that Nasser was cooperative in trying to reduce border tension; in abiding by agreements; and in demonstrating a

IbId., PP. 93-94.

${ }^{2}$ Copeland, The Game of Nations (New York), p. 156; E11is, Challenge in the Middle East, P. 42. 
wllingness to avoid trouble. Nasser had actually been seeking a peaceful settlement with Israel. In 1954, he tried to arrange a secret meeting with Moshe Sharett, ther. Prime Minister of Israe1, through the mediation of India's Ambassador in Cairo. On a visit to Israe1, Don Mintoff, later to become Prime Minister of Malta, and Maurice Orbach, a British M.P., carried a letter addressed to sharett from Nasser. Even after the Ghazzah raid of early 1955 and the Russian arms deal, Nasser warmly welcomed Anthony Eden's proposal in his November Guildha11 speech for a negotiated settlement of the ArabIsraeli dispute. It seems therefore, unfair in the light of the historic evidence for the West to label Nasser as an aggressive militaristic dictator, whose only passion was to incite hatred for Israel.1

It does not take a close examination to find out who obstructed peace efforts. The solution recommended by the United Nations for settling the Palestine refugee problem, through its resolution of 1948, had been reaffirmed by the U. N. General Assembly every year. But Israel never accepted it for the obvious reason that it was not consistent with the basic concept underlying the existence of a Jewish state. Therefore, the U.N. call to allow those Palestinian refugees who wished to return home was not heeded; neither were they repatriated. In fact the departure of the refugees seemed necessary, and Israel's policy worked to keep them out. Commander E. H. Hutchinson, the American Chairman of the United Nations Jordanian-Israeli Mixed

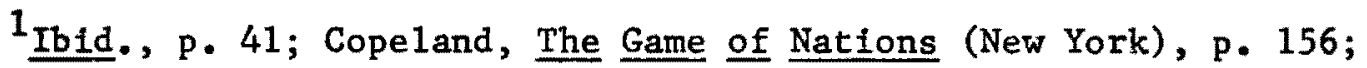
Hopkins, Egypt, The Crucible, pp. 169-71. 
Armistice Commission from 1949-1954, reported, "Few, if any of Israel's offers of peace, were matched by deeds that would invite cooperation. . Isrzel led by a good margin in serious violations of the border and armistice agreements." 1

\section{- 7 . THE RUSSIAN OFFER AND NASSER'S ACCEPTANCE}

In Apri1 of 1955, Nasser left for the Bandung Conference. On h1s way, he met Chou En-Lai in Rangoon, Burma, to whom he spoke of his dilemma, and asked if he thought the Soviet Union would sel1 arms to Egypt. Chou promised to convey Nasser's inquiry to the leaders of the Soviet Union. In May, after Nasser had returned from Bandung, the Soviet Ambassador Solod called on Nasser to hand him an important and secret message from Moscow, which is summarized by Mohammad H. Hayka1 as follows:

The Soviet Union respects Egypt's determination not to allow her land to become a military base in the Western plan to encircle the Soviet Union and place her under seige. Though the Soviet Union realizes that Egypt did so in her determination to preserve complete national independence, the Soviet Union does not feel that Egypt should be respected less for her stand. The least the Soviet Union can do to show her respect and appreciation is to grant Egypt's request to buy arms from her. 2

Several days later, Nasser told Ambassador Byroade that he was serfous about getting arms elsewhere should Washington's policy continue unchanged. Ambassador Byroade knew that Nasser was not bluffing. But when he informed the State Department, he was not taken

1Quoted in Ibid., p. 171.

2 Hayka 1, Nahnu . - wa-Amrika, p. 95. 
seriously. Nasser's last bid for U.S. arms came in June 1955. The conditions set by Washington and the assurances sought irritated him. He wanted arms with no strings attached. To make it difficult for Nasser, the U.S. Government informed him that the only way he could get U.S. arms was to pay for them in cash. His threats to buy arms from Russia were interpreted as blackmail by Washington. In his memoirs, former President Eisenhower says, "Our State Department, confident that he was short of money, informed him that payment would be expected in cash rather than barter... his threats to begin negotiations with the Soviets sounded suspiciously like blackmail."1 Eisenhower goes on to explain that though this American attitude may appear unrealistic, the truth was that his government was obliged to abide by the terms of the Tripartite Declaration of 1950 to help "maintain a rough balance between the military strength of Israe1 and the neighboring Arab states, a balance that this arms sale would have drastically disturbed."2

Nasser obviously could not afford to enter "into a purely commercial contract for 'dollar arms."'3 A loan from the U.S. for this purpose was out of the question. A military alliance with the West was not in accord with his policy of non-alignment and the Bandung spirit. In fact, a military alliance with the West would have been self-defeating because it would have never allowed any

${ }^{1}$ Dwight D. Eisenhower, Waging Peace, 1956-1961: The White House Years (Garden City, N.Y.: Doubleday, 1965), p. 24.

2 Ibid., p. 25.

${ }^{3}$ Dougherty, "The Aswan Decision in Perspective," 34. 
military operation against Israel--a restriction that he and other Arab nationalists would never have accepted.

If Nasser could suspend the idea of joining a Western alliance, he could not afford to keep his army officers without the arms they had been demanding. Neither would it have been wise to allow the military balance to tip in favor of Iraq and her "northern tier" neighbors. With Western help, those states were making noticeable military progress. ${ }^{1}$ Moreover, France agreed to sell fighter planes to Israel as early as $1954 .^{2}$

In July 1955, Ambassador Byroade made a special appeal urging Washington to grant Nasser's request. ${ }^{3}$ He was sure Nasser was going to obtain Soviet arms if his request was not granted. Byroade knew that Nasser was in danger of risking disaffection within his army. But Byroade's appeal had no positive effect. In fact, as Ambassador, he had by then lost most of his effectiveness in his efforts to help shape U.S. policy toward Egypt. He was constantly seen as one who had fallen under the spell of Nasser and his opinions were not taken seriously, especially when his views as Ambassador began to differ so much from his former views as Assistant Secretary of State. His troubles multiplied following an incident described by Miles Copeland and Mohammad H. Haykal as humiliating, and one that had adverse effects on his job as Ambassador.

$1_{\text {Paul E. Zinner, ed., Documents on American Foreign Policy, } 1955}$ (New York: Columbia University Press, 1956), pp. 342-44.

2 Hopkins, Egypt, the Crucible, p. 174.

${ }^{3}$ Copeland, The Game of Nations (New York), p. 155-56. 
The incident is reported to have taken place during a meeting In early 1955, Including, among others, Nasser, Byroade, Kermit Roosevelt, Eric Johnston, and Jaises Eichelberger. Rooseve1t was a special Washington messenger, who used to often appear in Egypt and in Nasser's company without the knowledge of the Embassy. Johnston was President Eisenhower's special envoy to help settle the problem of the Jordan waters. Eichelberger was an expert on military regimes In developing countries. Out of his frustration with his government and out of anger over the presence of Kermit Roosevelt with Nasser without his knowledge, Byroade abruptly tried to change the subject of the discussion by asking Nasser why one of the American Embassy's men was beaten up at Suez. Nasser replied that the man was a CIA agent and that the Embassy had been asked to keep him out of labor districts. Byroade then told Nasser that the Egyptian laborers' behavior (Copeland mentions the Egyptian police) was uncivilized. To which Nasser retorted, "I sha11 leave you tonight so you can read a book about Egyptian civilization and its ancient history, and when you learn something from it, we sha11 talk again!"1

This Is what Hayka1 calls the "Byroade Crisis." Byroade knew he committed a mistake and did not know how to apologize while Roosevelt and Johnston walked with Nasser to his car trying to apologize for him. The following day, a cable was sent to Washington by Johnston and Roosevelt to Dulles reporting the incident and stating that Byroade was no longer suitable to function as U.S. Ambassador in ${ }^{1}$ Ibid., pp. 161-62; Hayka1, Nahnu . - wa-Amrika, p. 85. 
Catro. This had taken place after a period of close friendship between Nasser and Byroade, during which the latter showed great understanding and sympathy for the Egyptian point of view; perhaps more than Washington wished him to. Nasser soon forgave him, but did Secretary Dulles? ${ }^{1}$ Nasser waited. He was actually trying to avoid accepting the Soviet offer: To Nasser's army officers, his stalling was unwarranted and his policy incomprehensible. The Soviet offer, they felt, should have been accepted inmediately. In June Nasser had proposed to Genera1 Burns the physical separation of Egyptian and Israeli forces by a demilitarized zone, and was prepared to accept Burns's proposal for joint Israeli-Egyptian patrols. Israel, however, rejected both of these proposals. On August 31, 1955, Israel struck once more with ferocity at Khan Yunis in Ghazzah, in retaliation for Fidaiyeen raids, and killed thirty-six Egyptians and Palestinians. Nasser could not possibly wait any longer. ${ }^{2}$

When Washington finally discovered that Nasser's threat to buy Russian arms was not a bluff, Kermit Roosevelt was dispatched to Cairo to try and dissuade Nasser from going ahead with the deal. When Nasser learned of this, he realized that Washington had discovered the facts and was about to apply pressure. He, therefore, decided to announce his acceptance of the Russian offer before the arrival of Washington's special messenger, and to an audience of not more than

ITbid.; Copeland, The Game of Nations (New York), pp. 162-65. 2 Hopkins, Egypt, the Crucible, p. 176; E11is, Cha1lenge in the Middle East, pp. 42-45. 
a hundred people in a sma11 ha11. Nevertheless, the news was out and was soon heard a11 over the world. Roosevelt met with Nasser for three days. He knew perfectly well what Nasser's dilemma was; he realized that Nasser had done his best and is reported to have had much sympathy for Nasser's position. Roosevelt, however, could not be of much help since Washington was adamant in 1 ts refusal to favorably consider Nasser's request. 1

While Roosevelt was still in Cairo, news was released through the Associated Press, not through the American Embassy in Cairo, of George Allen's expected arrival in Cairo with a note that contained a warning and a threat to take economic measures against Egypt. A11en was met at the Cairo Airport by Byroade and Rooseve1t, who urged him not to deliver the note. They both felt that his trip was unwarranted and its intended objective could only do further harm to U.S.-Egyptian relations. A1len was told that Nasser was doing his best under the circumstances. News of the note, however, had already done its damage and Allen said very little to newsmen at the airport because, before landing, his plane received a message from Byroade and Roosevelt describing the situation in Cairo as very explosive. Therefore, he should not, in any way, reveal that he had a warning or ultimatum to deliver to Nasser. ${ }^{2}$ Hayka1 reports that the Embassy officials' alarm was intensified when Nasser threatened not to receive Allen and to sever diplomatic relations with the United States

\footnotetext{
${ }^{1}$ Campbe11, Defense of the Middle East, pp. 72-73; Haykal, Nahnu .. wa-Amrika, pp. 86-92.

${ }^{2}$ Copeland, The Game of Nations (New York), pp. 65-67.
} 
should he even hint that he had an ultimatum. ${ }^{1}$ Allen met Nasser but only after waiting for an hour and a half in an outer office, and left without delivering the note. 2 The secretary in Nasser's office explained later, "We kept Mr. Allen waiting because we heard he intended to bang the table and give us a lecture. We kept him waiting to cool off. 'We kept him waiting until he agreed not to present the note he had been sent to deliver." 3 "It seemed that the incredible was happening," says Harry Hopkins, "the years of humiliation before the moral arrogance and material superiority of the West had at last begun to be repaid." 4

Nasser's acceptance of Russian arms was greeted with enthusiasm throughout the Arab world. He received congratulations even from Nuri a1-Said of Iraq. He "had almost overnight," says Harry Hopkins, "shattered the moral proprietorship which the British, French and Americans had so long, and so anachronistically, exercised over the whole region." Nasser accomplished that "by daring to deal with the Russians."5 Through Nasser's action, Russia made her first major debut on the Middle Eastern scene. Besides accepting Soviet arms in September, Nasser sent educational, political, and military missions

1 $\underline{\text { Ibid., p. } 101 .}$

${ }^{2}$ Copeland, The Game of Nations (New York), pp. 165-69; E11is, Challenge in the Middle East, pp. 41-46; Hopkins, Egypt, the Crucible, pp. 174-78.

${ }^{3}$ Robert St. John, The Boss: The Story of Gamal Abdel Nasser (New York: McGraw-Hil1, 1960), p. 210 .

${ }^{4}$ Ibid., p. 178.

${ }^{5}$ Ibid., p. 177 . 
to Arab capitals such as Amman, Beirut, Damascus, and Baghdad to he1p launch a campaign aimed at discrediting the policy of Nuri's government in Iraq and to carry a program of mass-education against the Baghdad Pact. Egypt's superior intellectual and ideological Arab leadership insured the success of this propaganda campaign against Iraq's proWest policies. With the Russian arms deal came the end of the Western monopoly and with it the end of the efficacy of the Tripartite Declaration of 1950 . 
CHAPTER VI

THE SUEZ CRISIS

Following Nasser's acceptance of Soviet arms and the failure of Kermit Roosevelt and George Allen to dissuade him from going ahead with the deal, Washington took several days to recover from the shock. The report delivered to Dulles by Roosevelt and Allen stressed the fact that there was nothing the United States could do, for Nasser had attained an impregnable position and was in the midst of an ocean of popular support and enthusiasm that was sweeping across the whole Arab world. In a report from Washington, Egypt's Ambassador Ahmad Hussein mentions that one of Dulles's aides told him that he could not avoid accepting the defeat at the hands of Nasser. In early November 1955, following extensive discussions at the State Department, in which the Departmert of Defense and the CIA participated, Dulles seemed to have been convinced that intimidation was not likely to influence Nasser but that an attractive offer might be successful. 1

With the hope that Nasser could still be won over, the U.S. continued to resist Israel's attempts to acquire American arms. When Israel intensified her demand for arms following the Egyptian-Soviet arms deal, the Egyptian government warned through its Arbassador in Washington that, if the United States supplied Israel with arms, the

${ }^{1}$ Dougherty, "The Aswan Decision in Perspective," 36; Haykal, Nahnu . - we-Ainrika, pp. 108-10. 
whole Arab world would assume that the U.S. had chosen sides and decided to openly invalidate her claim of being impartial. Dulles's reply to Isiael was that she still had a military advantage over her Arab neighbors and that the arms balance had not yet turned against her. To an inquiry by forty members of the House of Representatives, Secretary Dulles replied on February 6, 1956,

the security of Israel can perhaps better be assured by means other than an arms race.. . it is our belief that cho security of states in the Near East cannot rest upon arms alone but rather upon the international rule of law and upon the establishment of friendly relations among neighbors. 1

Israel continued to press for arms, however, and to argue that she could not afford to wait until the balance shifted in favor of the Arabs. 2

\section{THE ASWAN DAM OFFER}

To lure Nasser, Dulles selected a project that was important to Nasser and the Egyptians; one that was being intensively studied in Egypt and was the great hope for continued economic development, namely the High Aswan Dam. It was this Dam that the U.S. and Britain made a definite offer to help Egypt build. The offer was formally made in December 1955 in an apparent attempt to persuade Nasser to efther cancel the arms deal with Russia or to, at least, keep him from making further purchases. A most effective way to keep Nasser from making further arms purchases from the Soviet Union would have 285-86.

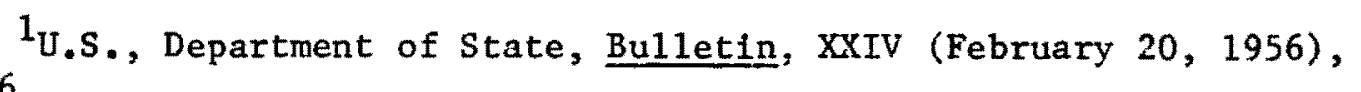

2Fitzsimons, "Suez Crisis and the Containment Policy," 436-37. 
been to sell him American arms. But since the creation of the State of Israel, the U.S. steadfastly refused to supply Egypt with arms. American arms went to pro Nestern Arab states such as Saudi Arabia, Jordan, Iraq and Lebanon, but not to militant Egypt and Syria. The U.S. hoped the Aswan Dam offer might induce Nasser to concentrate his efforts and financial resources on internal reform and development and forsake his other ambitions, making arms unnecessary. Western aid and influence and the employment of Egyptian resources, it was hoped, would help keep Nasser from developing closer relations with the Soviet Union and from making further purchases of eastern bloc arms. 1

The estimated cost of the Dam was $\$ 1,300,000,000$. The U.S. was to lend Egypt $\$ 56,000,000$, Britain $\$ 14,000,000$, and the Wor $1 d$ Bank $\$ 200,000,000$. The rest was to be supplied by Egypt in the form of materials and labor. Had this offer been agreed upon, its terms would have compelled Nasser to practice moderation and economic austerity for a perlod of not less than ten years, if not fifteen. Egypt would have had to comply with the demands of the World Bank to fight inflation and to have her investments, expenditures, as we11 as the Dam Project's requirements reviewed periodically. Egypt would also have had to avoid foreign debts in excess of amounts both Egypt and the World Bank agreed upon. There are indications that Nasser had tentatively agreed to some of these

IIbid., 437; Dougherty, "The Aswan Decision in Perspective," 36-37; Finer, Dulles over Suez, p. 36; Haykal, Nahnu . . Wa-Amrika, pp. $109-10$. 
terms of the offer. 1

By early 1956, however, the Egyptian government had already mace enough commitments to cause concern in Washington. ${ }^{2}$ Nasser obviously wanted and needed arms as much as he needed economic aid. He thought his policy of tactical positive neutralism would guarantee him arms from the East and economic aid from the West. But the heart of the problem was that the West did not wish to grant economic aid to a regime that was becoming increasingly dependent on the Soviet Union for the supply of arms. They also were sensitive to any development that carried with it any signs of possible danger to the safety and security of Israel. According to James Dougherty, Assistant Professor of Political Science at St. Joseph University, Philadelphia, and Fellow of the Foreign Policy Research Institute of the University of Pennsylvania, "a major objective of American policy became the prevention of a situation from arising in which the United States might be forced to go to the aid of Israel in the event of a formidable Arab attack." 3

Nasser, too, was aware of the irritations the Western offer contained. Malcolm Kerr observes, "the requests by Mr. Eugene Black, the President of the Bank, for powers of supervision of Egyptian finances served the purpose, whether intentionally or not, of reminding Nasser of Ang10-American political requirements." 4

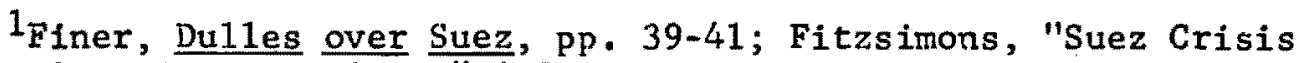
and the Containment Policy," 438 .

${ }^{2}$ New York Times, February 10, 1956.

3Dougherty, "The Aswan Decision in Perspective," 37.

"Kerr, "Coming to Terms with Nasser'," 71. 
Those political requirements included veiled demands that Egyptian incitements and attacks aimed at them and their friends in the area be stopped. A Nasser-West cooperation depended on those declared and undeclared Western conditions. But Nasser had demonstrated clearly enough that he was not about to acquiesce to all Western demands. His attacks against the Baghdad Pact continued; Egypt recognized mainland China; terrorist attacks against Israel were intensified, and purchase of eastern bloc arms increased. Nasser was determined not to pay the price the West was asking of him. He was convinced aid was coming either from the West or from the East on his own terms. If it came from the West, it would have meant that the West had acknowledged him as leader in the area. 1

In October 1955, a consultant and an engineer from the World Bank went to Egypt to study the project in compliance with an Egyptian request. Egyptian officials were apparently anxious to get a firm conmitment that the Bank would help finance the High Dam project. Egypt indicated that she intended to go ahead with the project either by financing the dam with funds from the Bank, the United States and other Western sources of credit or by accepting help from the Soviet Union. 2

During and after Dimitri Shepilov's visit to Cairo in June 1956, Egypt was reported to have received an offer of a $\$ 1,120,000,000$ loan for 20 years at the rate of $2 \%$ interest. 3 But Mr. Shepilov, the Soviet Foreign Minister who was reported to have made the

${ }^{1}$ Ibid., $71-72$.

International Organization, X (February, 1956), 194.

3 New York Times, June 20, 1956. 
offer, never came out to publicly confirm it. In fact, the Soviet Embassy in Cairo denied the report a few days after Shepilov left Cairo. Shepilov himself, wisen back in Moscow, stated that the Soviet Union would favorably consider Egypt's requests for Soviet aid in her industrial development, but that aid for the High Aswan Dam was not being considered then. 1 Nevertheless, Nasser continued to show confidence that Soviet aid was available. 2 Secretary Dulles, according to John Beal, his biographer, "firmly believed the Soviet Union was not in a position to deliver effectively on all her economic propaganda offers." 3 The assumption in Washington, therefore, was that the choice for Nasser was either to accept the Western offer and abandon his policies or pursue the same policies and go without the High Dam.

II. THE WITHDRAWAL

If Nasser's plans for Egypt's army were not yet known to some, the military parade of June 18, 1956, was a dramatic demonstration of his unbending determination to make Egypt capable of defending herself against Israeli attacks. That parade made it plain that the hope of achieving the intended objective of the Dam offer was dubious. The United States had obviously not concerned herself much with the question of the value of the Aswan Dam for

1 Ibid., Ju1y 22, 1956.

I Ibid., July 24, 1956.

3John Robinson Beal, John Foster Du11es: 1888-1959 (New York: Harper, 1959), p. 25. 
Egypt's economy or whether it would help feed the hungry or improve the every-day 1ife of the Egyptian poor. These were not the primary American concerns. In the mind of Dulles were greater global and local issues: (1) Russia was not to be allowed to capitalize on her success and (2) Israel's security was not to be threatened at any cost to the U.S. even the loss of Egypt's and Arab friendship. The June parade seems to have caused Washington to resolve to follow different means of achieving its objectives in the Middle East. In the following months, signs of change in the American attitude began to show. Rumors were heard of possible reassessment of the Aswan Dam offer due to Nasser's recognition of the People's Republic of China, his close ties with communist countries, and his Increased purchases of eastern bloc arms, which supposedly disturbed Egypt's balance of payments. On July 6 a Department of State announcement revealed that funds set aside for the Dam project were re-allocated, even though the U.S. was still ready and willing to help Egypt. 1

The withdrawal of the Dam offer on July $19^{2}$ came after the U.S. had apparently given up on Nasser. But it was done hastily and without much thought as to its possible impact on Nasser, the Arab people in genera1, and as to its consequences for the U.S. and her allies in particular. Muhammad H. Haykal states that Dulles changed his mind about the offer two weeks after it was made, and did so for the following reasons: (1) he felt Nasser had injured

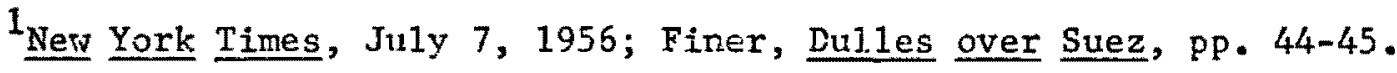
${ }^{2}$ Current Documents, 1956, pp. 603. 
America and challenged him (Dulles) personally by refusing to cancel the arms deal with Russia; therefore the U.S. should not have decided to reward him by helping him to build the Dam; (2) the reports from the American Embassy in Cairo indicated that Nasser persisted in buying additional Soviet arms and was not likely to respond to American pressures; (3) America's major allies were very unhappy wth Nasser. Britain held him responsible for her troubles in the area and France was irritated over the help the Algerian rebels were supposedly receiving from Egypt; (4) America's minor allies were filled with bitterness. The reports of American embassies in Baghdad, Ankara, Tehran and Karachi, reflected the fears and sorrows of Nuri al-Said, Adnan Menderes, Mohammad Ridha Pahlavi and Sahrawardy, and they all said it as it were in one voice: "Nasser has proved to our people that to rebel against U.S. policy is more rewarding than loyalty to it."1

The decision to withdraw the offer was kept for six months in Dulles's "pocket," contends Haykal, in order that it might be announced at a time when it could be most effective. In the meantime Nasser falt that his Soviet source of arms might be blocked when Bulganin and Khrushchev went to London and were asked about the possibility of an agreement to control the supply of arms to the Middle East. Though the two Soviet leaders refused to sign such an agreement, Nasser felt he had to have another source handy just in case. That is mainly why he recognized the People's Republic of 1 Hayka1, Nahnu . . Wa-Amrika, p. 111. 
China. 1

Both Furgh Thomas and Muhammad H. Haykal contend that Nasser was convinced the U.S. was not guing to make good her offer. Haykal notes that Nasser told Dr. Ahmad Hussein, his Ambassador to Washington, "even if we accept a11 their conditions, they will still refuse." Thomas argues that Nasser was not even sure whether he really wanted the money from the West. But while Thomas says that it was Dr. Hussein who persuaded Nasser "to make a final bid for Western aid," Haykal says that Nasser directed his Ambassador to return to Washington and tell Secretary Dulles that Egypt had accepted all his conditions for America's participation in financing the Dam project because he wanted to bring the matter to a head. Haykal goes on to say that even Dr. Hussein's statement in London, to the effect that Egypt had accepted America's conditions and that he was on his way to inform Dulles of Egypt's acceptance, was prearranged. 2

When the Egyptian Ambassador went to see Dulles, the Secretary met him with a copy of the withdrawal announcement. As he left Secretary Dulles's office, the Ambassador saw, to his surprise, that the representatives of the press had already received copies of the same announcement. Part of the State Department announcement said, "the ability of Egypt to derote adequate resources to assure the project's success has become more uncertain than at the

I Ibid., FP. 112-13.

2Ibid., p. 114; Hugh Thomas, The Suez Affair (London: Weidenfeld \& Nicolson, 1966), p. 24 . 
time the offer was made." 1 The other reason given was that Egypt had not secured the necessary agreements with the other riparian states (i.e., Sudan, Ethiopia and Uganda). 2 "The American Se-retary of State," says Harry Hopkins, "had invited the Egyptian President to stand on his carpet--and now he had snatched it from under his feet." 3

American policy makers, especially Secretary Dulles, had apparently arrived at the conclusion that there was no hope of restraining Nasser by trying to appease him. They watched Nasser draw closer to the Soviet Union and the eastern bloc; they heard him and his colleagues adopt a sharper anti-Western tone; they witnessed the flow of Russian arms into Egypt and saw how Egyptian resources were being earmarked for those and future shipments; and they sadly received the news of Egypt's recognition of the People's Republic of China. At home the Congress refused to grant the Administration authority to negotiate long-term commitments with foreign countries; the Aswan Dam project came under attack from proIsraeli and cotton-interest groups; this at a time when Presidential elections were at hand and when American politicars paid more attention to the demands of special interest groups. The problem with Nasser is summed up in what Nikita $S$. Khruschev is reported to have said when commenting on the Suez crisis and the events leading to it a

1 New York Times, July 20, 1956; Current Documents, 1956, p. 604. 2Ibid., pp. 603-4.

3 Hopkins, Egypt, the Crucible, p. 179. 
short time before his death. Egypt refused "to follow the path set for it by the United States, England, and France," said Khrushchev; that is why the Dam loan was withdrawn. 1 But the main reason for the withdrawal may have been what Robert Murphy wrote in his book, Diplomat Among Warriors. Murphy says that though he and his colleagues "who worked with Dulles were never told explicitly why he acted so abrupt1y," they

surmised that perhaps the main reason was because Nasser was scheduled to make a trip to Moscow early in August. If the United States would agree to the Aswan Dam financing, the Egyptian President could then concentrate in Moscow on concluding his second big arms deal with the Russian, thus getting the best of both worlds. Dulles guessed accurately that Nasser would not journey to Moscow at all if the Aswan Dam offer were rescinded, because that would compel the Egyptian to go hat-in-hand not only with regard to the High Dam project but on the arms deal as we11.2

A11 these factors must have played a role in inducing Dulles to withdraw the Dam offer. But they were not the only ones. Dulles, no doubt, wished to, in the words of John Beal, "expose the shallow character of Russia's foreign economic pretentions." 3 He also had a reason for his publicized refusal. Speaking for Dulles, John

Beal says,

It was necessary to demonstrate to friendly nations, by act rather than by oral explanation, that the U.S. tolerance of nations which felt it necessary to stay out of Western defense alliances could not brook the kind of insult Nasser presented in his repeated and accumulated unfriendly gestures. . . The choice was between letting

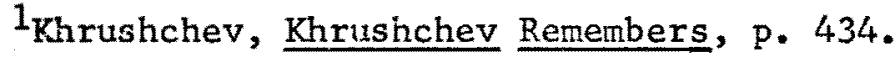

2Robert Daniel Murphy, Diplomat Among Warriors (Garden City, New York: Doubleday, 1964), p. 377.

${ }^{3}$ Beal, John Foster Du11es, p. 260. 
him down easily, through protracted negotiation that came to nothing, or letting him have it straight. Since the issue involved more than simply denying Nasser money for a dam, a polite and concealed rebuff would fail to make the really important point. It had to be forthright, carrying its own built-in moral for neutrals in a way that the omolu of applied propaganda would not cheapen. 1

Moreover Dulles felt that Nasser must not be allowed to "blackmail" the United States. He, therefore, in Senator Hubert Humphrey's opinion, "withdrew the offer with the clear intention of punishing Nasser in the eyes of the world for making a deal with the Soviet Union to obtain the arms which we $\bar{L} \cdot \bar{i}_{.} .$, the U.S. $/$had refused to se11 him." 2

But what did the objective of "punishing Nasser" mean? Did it mean punishing Egypt and the Egyptians? Did it mean punishing the Egyptian army that brought Nasser to power? Did it mean punishing the Egyptian regime that was in power then? Did it mean punishing Nasser as an individual? Did it mean punishing him as the leader of a popular movement that was the moving force throughout the Arab world? Whatever the objective was, it ought to have looked impossible to achieve to any serious observer of the situation. It is difficult to ascertain what the State Department hoped to accomplish by withdrawing the offer, and in reflection, the more obvious is the unwisdom of that decision.

Nasser's position was strong enough not to be easily toppled or shaken to the point where he would have abandoned his Soviet

$1_{\text {Ibid., Pp. 258-60. }}$

2Humphrey, "A Chronology of Fallure," 13. 
friends. British troops were no longer on Egyptian soil, and their departure in June of that year awarded Nasser the applause and congratulation of the Arab wor1d. Nassei's popularity was at its height following the arms deal with Russia and his being at the head of a new constitutional regime that had replaced the Revolutionary Command Council. General Neguib had already been placed under house arrest and Nasser faced no serious challenges from the Wafdists, the Muslim Brothers, or from his army. Demonstrations and demonstrators were in full support of his government. His fellow officers respected and honored him because they acknowledged his superiority over them in his intellectual abilities, his political courage, his boldness, and uprightness. They were committed to him not only because they admired and trusted his strong leadership, but also because they realized that to him they owed most of their political fortunes. Indeed his position in Egypt, if not in ail the Arab world, was practically impregnable and unassailable, and his policies until then had received overwhelming public approval. ${ }^{1}$

The voices heard from Cairo were not raised against Nasser. Washington might have expected or, at least, desired that the Egyptian people would rise against Nasser. Instead the Egyptian and Arab public lashed back at the United States in tones of extreme bitterness and hostility. The reasons for the withdrawal of the offer, the Egyptian press claimed, were Israel, American cotton growers, and the Republican Party's concern over Jewish money and

$1_{\text {Finer, Dulles over Suez, pp. 54-55; Dougherty, "The Aswan }}$ Decision in Perspective," $\mathrm{pp} \cdot 38-39$. 
votes in the fall elections of that year. What hurt the Egyptians most was the claim in the State Department statement that Egypt's economy was unsound. 1

\section{NASSER'S NATIONALIZATION OF THE CANAL}

The withdrawal of the Western offer, Mr. Dulles thought, left Nasser with the choice between two alternatives. Dulles assumed that Nasser would either ask the Russian for a loan (and thus put them on the spot), or abandon the project completely. Nasser did eventually ask the Soviet Union for the money and received it in 1958 . But he had a third alternative that Dulles apparently was not aware of at the time. Before getting a loan, Nasser wanted to avenge injured Egypt. That was to be his first and primary task--to take an action that would inflict an injury on the West that would more than equal the injury to Egypt's pride.

His dramatic action came in a week's time and fell like lightning upon a confounded West ${ }^{2}$ and a bewildered world, whose one third exploded in thundering cheer and overwhelming joy. Nasser's nationalization of the Suez Canal on July $26,1956,{ }^{3}$ caused his popularity to rise to new heights in the Arab world. His action

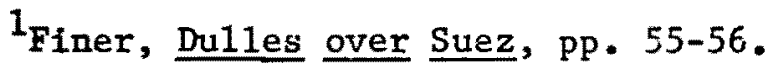

${ }^{2}$ See Thomas, The Suez Affair, p. 26; Murphy, Diplomat Among Warriors, p. 378.

${ }^{3}$ See Nasser's Nationalization Order in Current Documents, 1956, pp. 604-06. 
provoked his enemies, especially Britain and France, and converted what looked like a major rebuff, if not a defeat to his policy, into a resounding victory. It represented a major triumph of Jasser's nationalist policy that even his rivals commended him for it. Muhammad H. Hayka1 notes that Nasser, before making his historic announcement, wrote his own appraisal of the situation. He then asked two or three of his closest associates to make an assessment of the British and French positions. Israel was counted out as unlikely to participate in hostilities against Egypt at that time. Enough information was gathered to show that the British and French could not mount a successful military attack in a period less than two months. That was all Nasser wanted to know before he made his nationalization speech in Alexandria. 1

The surprise shown by the West was not justified. The provocative nature of the decision to withdraw the offer was bound to evoke a strong Egyptian reaction that was meant to hurt the West. Secretary Dulles had apparently failed to make serious calculations or to anticipate such a move. 2 Anthony Eden commented later, England was not able to do anything about the publicized withdrawal

1a1-Ahram (Cairo), September 24, 1971.

${ }^{2}$ See Robert Murphy, Diplomat Among Warriors, p. 377. Murphy recalls that Dulles had not consulted his staff on the matter; he did not consult with him (Murphy), as a Middle East hand then; he did not tell President Eisenhower until "the morning of Hussein's visit"; he did not inform the British Ambassador until one hour before the announcement was made; and Eugene Black, the President of the World Bank, "was particularly distressed by the sudden cancellation." 
announcement since she was "informed but not consulted and so... had no prior opportunity for criticism or comment."1 Nevertheless, England followed suit two days Iater. Eden admits that his government had by mid-July come "to the conclusion that they could not go on with a project likely to become increasingly onerous in finance and unsatisfactory in practice." But the British government's decision was not made pub1ic because Eden "would have preferred to play it long and not to have forced the issue." 2 "The public refusal," says M. Fitzsimons, "does suggest that a firm hand and clear mind were not controlling American decisions at that time." 3

On Aligust 12, during a press conference, Nasser stated that his decision to nationalize the Suez Canal Company was not made unt11 the United States withdrew the offer to help build the High Aswan Dam. He also assured the Western powers that his decision was done by Egypt alone and that the Soviet Union had nothing to do with it. 4

The act of nationalization was extremely satisfying because it was not only an answer to an intended rebuff, but also because it was against a symbol of colonial exploitation. Egypt had provided

$1_{\text {Eden, Full Circle, p. } 470 .}$

2Ibid.

3Fitzsimons, "Suez Crisis and the Containment Policy," 440.

4Egyptian Gazette (Cairo), quoted in Dougherty, "The Aswan Decision in Perspective," 42. 
up to three quarters of the Canal's cost in land, money, and labor. But, until the mid-1930's, Egypt was not paid anything back except an annual renta1 charge of $\mathrm{EE} 300,000$, which was not brought up to 7 percent of the annual revenue from the Canal until 1949, and only under heavy nationalist pressure. By 1955, the 44 percent share sold to Britain by the Khedive Ismail reached a market value of EE 7,000,000, and an annual yield of about EE 3,000,000. To add insult to injury, the Canal Company practiced job discrimination against Egyptians. Harry Hopkins observes,

Few Egyptians were employed except in very subordinate posts; the first Egyptian pilot did not appear until 1947, and then only under heavy Government pressures. A wel1educated Egyptian who had applied for a post there as a young man said: "As soon as they knew you were Egyptian, you were out. They would take the lowest sort of Maltese or Greek rather than an Egyptian, no matter how well qualified." 1

That is why nationalization met with "an explosion of joy which united al1 classes in Egypt. And not only in Egypt--for . . the thunder of occasional lightning of applause swept the entire Arab world from the Gulf to the Atlantic." 2 Hopkins adds,

"The Suez Cana1 . . . is an integral part of Egypt"-art. XVII Anglo-Egyptian Evacuation Agreement, 1954. What the Company held was an operating concession granted in 1888, expiring in 1968 , not the ditch itself.$^{\circ}$. . In 1956 , fair compensation was offered--and paid. $3^{\circ}$

In his memoirs, President Eisenhower is in agreement with the view

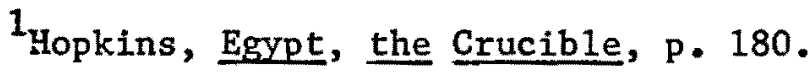

2 Ibid.

${ }^{3}$ Ibid., $n$. 
expressed in the above quote. He says,

The weight of world opinion seemed to be that Nasser was within his rights in nationalizing the Canal Company . . . The inherent right of any sovereign nation to exercise the power of eminent domain within its own territory could scarcely be doubted, provided that just compensation were paid to the owners of the property so expropriated. The main issue at stake, therefore, was whether or not Nasser would and could keep the waterway open for traffic of all nations, in accordance with the Constantinople Convention of 1888.1

That is why, Eisenhower says, "In my telephonic and other communications with Prime Minister Eden I frequently expressed the opinion that the case as it stood did not warrant resort to military force."2

\section{THE WEST'S REACTION}

To Nasser's nationalization of the Canal, there was no concrete allied reply as Anglo-American cooperation showed signs of breaking down. The statements made and the measures taken were day-to-day improvisations along with a steady and desperate Anglo-French resolve to use force.

A statement released by the State Department on July 27 declared that Nasser's action of July 26 carried "far-reaching imp1ications."3 On July 28, the State Department protested to Ambassador Hussein "the tone and content of statements made with respect to the United States by the President of Egypt."4 On Ju1y 29, Secretary Du1les

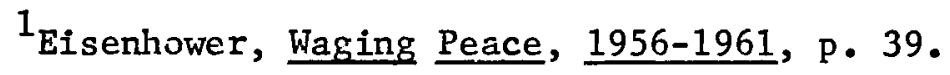

2 Ibid.

${ }^{3} U_{. S}$., Department of State, Builatin, XXXV (August 6, 1956), 221. 4. Ibi]., 222. 
declared that Nasser's action struck "a grievous blow at international confidence." 1 The United States, Britain and France issued a joint statement on August 2, following an agreement among them in London to call a 24-power conference to deal with the Suez Canal problem. ${ }^{2}$ In a Radio and TV Address on August 6, Mr. Dulles declared, "To permit this to go on unchallenged would be to encourage a breakdown of the international fabric upon which the security and the we11being of all peoples depend."3 During the London Conference, Secretary Dulles said on August 16, "Egypt seizes hold of a sword with which it could cut into economic vitals of many nations... what is required is a permanent operation of the Canal under an international system."4

But despite all this talk, Washington was determined not to use force. Secretary Dulles declared on August 3, "We do not ... want to meet violence with violence." 5 According to Hugh Thomas, even while Dulles was still in Peru, "the State Department quickly decided that they would not regard this event as an occasion for the immediate use of force--indeed the idea never occurred as a remote possibility--and told the British and French ambassadors so."6

$1_{\text {Ibid. , } 221 .}$

${ }^{2}$ For text of Tripartite Statement on the London Conference, see U.S., Department of State, Bulletin, XXXV (August 13, 1956), 262-63.

$3_{\text {Ibid. , } 260 .}$

${ }^{4}$ Ibid., 337.

5 Ibid., 262.

6 Thomas, The Suez Affair, p. 49. 
The British and French initial reaction, on the other hand, was to use force immediately. The day Nasser nationalized the Cana1, Nu-i al-Said and Crown Prince Abdel Ilah of Iraq were in London. Eden says in his memoirs that they "understood at once how much would depend upon the resolution with which the act of defiance was met."1 They warned, Eden adds, "several times of the consequences of Nasser succeeding in his grab. They would be swept away."2 Nuri is reported to have demanded, "Hit him, hit him hard and hit him now."3 Crown Prince Abdel Ilah, according to Harry Hopkins, "had told Colonel Gerald de Gaury that unless the British army intervened and toppled Nasser 'within a few weeks' it would be 'too late. 114

Robert Murphy, who in the absence of Secretary Dulles in Peru, was sent by President Eisenhower to London "'to see what it was a11 about"" and to "'hold the fort, "'5 reported back on July 30 that France and England had decided "to employ force without delay or attempting any intermediate or less drastic steps." 6 In his memoirs, President Eisenhower says that he, by July 31, had received news "that the British government had taken a firm decision to 'break

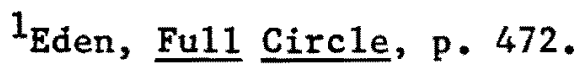

2 Ibid., p. 520 .

3 Thomas, The Suez Affair, p. 31.

4Hopkins, Egypt, the Crucible, p. 185.

5Murphy, Diplomat among Warriors, p. 379.

${ }^{6}$ Eisenhower, Waging Peace, 1956-1961, p. 664 (1etter to Eden, Ju1y 31,1955 , Appendix $B$ ). 
Nasser' and to initiate hostilities at an early date for this purpose."1 With Secretary Dulles, who left for London July 31 , Eivenhower sent a letter to Eden in which, after he suggested a conference on Suez, said, "For my part, I cannot over-emphasize the strength of my conviction that some such method must be attempted before action such as you contemplate should be undertaken." 2

On the same day, Nasser made an announcement in Cairo to the effect that, unless there was outside interference, norma1 trade between Egypt and the United Kingdom did not have to be disturbed, and that navigational freedom in the Canal would be guarded. He warned, however, that Egypt would fight if the West intervened militarily. On this, Nasser obtained the support of the Soviet Union, which was confirmed in a public statement by Khrushchev. 3 Britain and France accepted Dulles's suggestion to call a conference of 24 maritime powers to begin Augist 16 because the British Chiefs of Staff reported that "if there were no U.S. help, an Ang1o-French military force capable of restoring international control of the Canal Zone could not be mounted for at least six weeks."4 Dulles also comforted Eden by saying that "a way had to be found to make Nasser disgorge what he was attempting to swallow."5

$1_{\text {Ibid., p. } 40 .}$

2 Ibid., p. 664 , Appendix B.

3 Ibid., p. 41.

4Thomas, The Suez Affair, p. 55; see also, Eisenhower, Waging Peace, 1956-1961, p. 40 .

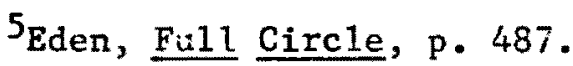


The United States and her allies were sure Egypt could not run the Canal. Jacques Georges-Picot, the President of the Suez Canal Coupany, hai repeatedly stated that Egypt could not run the Canal without his Company's pilots. To keep the Canal running while attempts at a peaceful settlement were being tried, Britain and France decided on August 2 to delay the withdrawal of the Suez Cana1 Company employees planned by the Company. ${ }^{1}$ The idea was that, in case a negotiated settlement were not reached, French and British pilots would be withdrawn; traffic through the Canal would be disrupted, and a cause for the use of force against Egypt would be provided.

The London Conference dispatched the Menzies ${ }^{2}$ Mission to Egypt. Nasser received the Mission and 1istened to the proposals of the London Conference but no agreement was reached. President Eisenhower's remark during a press conference while the Menzies Mission was stil1 in Egypt, to the effect that it was a peaceful settlement the United States sought, may have strengthened Nasser's resolve not to agree to any concessions. By September 11, Secretary Dulles had worked out and revealed the idea of the Suez Canal Users's Association. SCUA accomplished for Dulles what he sought--a postponement of Ang1oFrench plans to attack Egypt in mid-September. 3

On September 14, British and French pilots walked off their

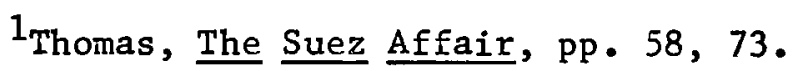

${ }^{2}$ Prime Minister of Australia.

3homas, The Suez Affair, Pp. 73-77. 
jobs at Suez. Colonel Mahmud Yunis and his aides, left with twentysix pilots and thirty trainees out of two hundred and fifty pilots normally required, ran the Canal without a hitch. ${ }^{1}$ Fifteen Soviet pilots arrived the night British and French pilots left. Other volunteers joined from the United States, India, Iran, Greece, and elsewhere.

The fact that Egypt was able to run the Canal smoothly and efficiently after the Company's installations were taken over in Cairo, Port Said, Port Tawfik, and Ismailiya, and after French and British pilots left, astounded the West. This discovery strengthened Western suspicions that Nasser had prepared to nationalize the Canal long before July 26, and there seems to be sufficient evidence to suggest that Egypt had, for sometime, been preparing to take over the Canal. However, the retraction of the Dam offer seems to have hastened it. The Canal concession was due to expire in 1968, and the mood in Egypt was against its renewal. So it is very likely that the Egyptian authorities were planning its nationalization in 1968, at the latest. The fear in Egypt was that Britain and France might try to renew the concession or attempt to place the Canal under international control. Since early 1955, the Company began to seek the aid of American oil companies in an effort to extend the concession. 2

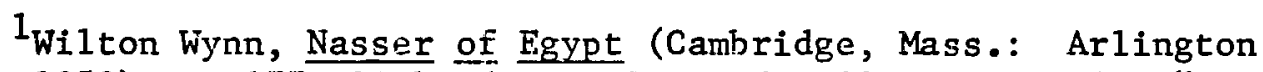
Books, 1959), p. 177; Richard H. Nolte and William Roe Polk, "Toward a Policy for the Middle East," Foreign Affairs, XXVI (July, 1958), 655.

2Dougherty, "The Aswan Decision in Perspective," 42-43; Thomas, The Suez Affair, p. 24. 
James Dougherty says that there were rumors in Egypt, severa1 months before the nationalization of the Canal, of a board of directors that had been formed to work secretly on nationalization plans. Dougherty cites the Egyptian journal, Sabah al-Khair, as saying that "the problem of nationalization had been studied under Nasser's personal direction since February 1956."1 A Russian source confirms, "The Egyptian government had long been preparing to nationalize its own property, which had been seized by the imperialists. Dulles's decision to withhold financial assistance only precipitated watters." 2 On the first day of the London Conference (August 16), Secretary Dulles said, "Speaking on August 12, 1956, he $/ \bar{N}$ asser $\bar{T}$ said that he had been thinking about it for two and a half years." 3

Once Egypt proved that she could run the Canal efficiently, the major reason for a military attack against her was removed. In his memoirs, President Eisenhower says,

not only were the Egyptian officials and workmen competent to operate the Canal, but they soon proved that they could do so under conditions of increased traffic and with increased efficiency . . any thought of using force, under these circumstances, was almost ridiculous. 4

From then on America's preoccupation became a concerted effort to keep Britain and France from attacking Egypt. But Britain and France

${ }^{1}$ Sabah a1-Khair (Cairo), August 2, 1956, cited in Dougherty, "The Aswan Decision in Perspective," 44.

2Georgi Ushakov, "Dulles' 'Aswan Gambit': the Story of a ColdWar Fiasco," New Times (Moscow, May 19, 1964), p. 28.

${ }^{3}$ U.S., Department of state, Bulletin, $\operatorname{xxxV}$ (August 27, 1956), 336. 4 Eisenhower, Waging Peace, 1956-1961, p. 51. 
were convinced that Nasser could not be retrained through diplomatic means, that he was bent on inflicting injuries on the West and that he was likeiy to be more danaging unless ne was checked. In fact, Eden's mind had apparently been made up since the dismissal of General Glubb in March as Commander of Jordan's Arab Legion. He blamed Nasser for his dismissal. Shortly afterwards, he is reported to have told Anthony Nutting, Minister of State at the Foreign Office,

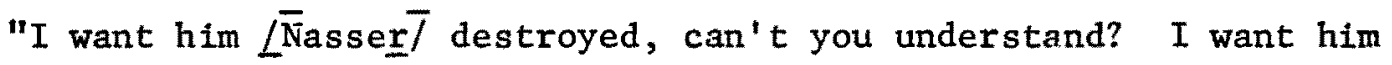
removed, and if you and the Foreign office don't agree, then you'd better come to the Cabinet and explain why." When Nutting tried to expiain that "At the moment there did not appear to be an alternative, hostile or friendly. And the only result of removing Nasser wotild be anarchy in Egypt," Eden replied, "But I don't want an alternative... And I don't give a damn if there's anarchy and chaos in Egypt."1

The Americans, detecting clear signs of a continued strong inclination on the part of their allies to use force, cautioned that the use of force, besides violating the United Nations Charter, could very possibly lead to a general war. On October 2, 1956, Secretary Dulles, in a news conference, explained the independent policy of the United States on the Suez problem as follows:

As far as the formula for the users association is concerned, there . . was drawn up a draft of the charter... There is talk about the "teeth" being pulled out of it. There were never "teeth" in it, if that means the use of force....

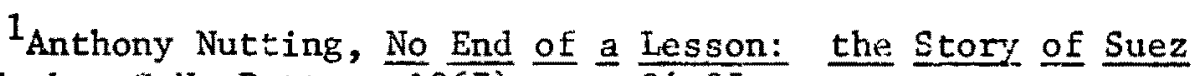
(New York: C.N. Potter, 1967), pp. $34-35$. 
Now there has been some difference in our approach to this problem of the Suez Canal. This is not an area where we are bound together by treaty. . . There are also other problems where our approach is not always identical. For example, there is in Asia and Africa the so-called problem of colonialism. Now there the United States plays a somewhat independent role . . . and that makes it impractical for us, as I say in every respect to identify our policies with those of other countries on whichever side of that problem they find their interest. 1

\section{OPERATIONS "MUSKETEER" AND "KADESH"}

On the Suez question the United States took the lead in opposing the use of force. On his three trips to London during the crisis, Dulles's efforts through the London Conference and the Users's Association were aimed at not only reaching a solution of the problem through negotiation, but also at gaining time with the hope that Anglo-French resolve to use force might weaken. In his public statements, Dulles made it clear that the United States would oppose the use of force. Eden, however, did gain the impression that Washington would not oppose an attack on Egypt if a11 attempts through negotiation falled. After all, it was Dulles who told Eden, "a way had to be found to make Nasser disgorge what he was attempting to swa11ow." 2 But Dulles's public statements, meant to disassociate the United States from British colonialism, infuriated Eden. ${ }^{3}$ 577.

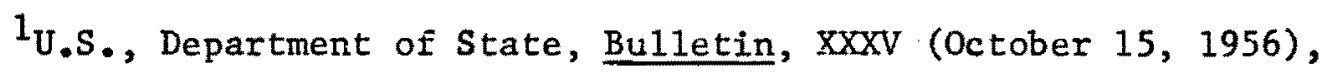

${ }^{2}$ See footnote 52 above.

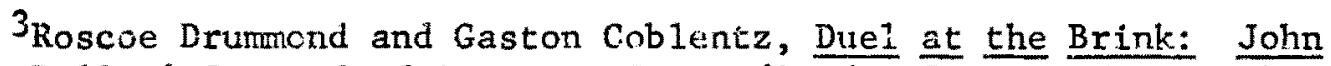
Foster Dulles' Comand of American Power (Garden City, N.Y.: Doubleday, 1960), p. 172. 
M. H. Haykal argues that Dulles preferred the use of methods other than military to force Nasser to "disgorge what" he "was attempt$1 n_{b}$ to swallow." The difference in views between Dulles and his allies, therefore, according to Haykal, was not a difference in the aim but in the method. Dulles, says Haykal, urged an assault against Nasser from within; he sought the 1iquidation of the Egyptian Revolution but without much fuss; he sought Nasser's defeat but not through the use of bullets. 1 What Haykal is implying here is, no doubt, the use of the same tactics used to bring down Dr. Mohanmed Mossadegh in Iran in 1953.

Another means "hidden, in the recesses of the State Department's files" was "Mr. Dulles's incomplete but implementable pian to 'bring Nasser down through economic pressure."'2 In New Times, Georgi Ushakov contends that Dulles showed an inclination to use force if it could help topple Nasser, but later changed his views because he saw it could not succeed. 3

As the Menzies Mission, the Users's Association, and the United Nations failed to accomplish what the British and French sought, and as Washington became more resolute and open in its opposition to the use of force, "Eden decided that from then on, the less said to Dulles, the better."4 As Anglo-French war preparations began in earnest, "a

$1_{\text {Hayka1, Nahnu }}$ - . wa-Amrika, p. 117.

2"The Eisenhower Doctrine: Beginnings of a Middle East Policy," Round Table, XLVII (March, 1957), 141.

3Ushakov, "Du1les' 'Aswan Gambit'," 185.

4Drummond, Due1 at the Brink, P. 174. 
blackout in communications had been imposed," says President Eisenhower in his memoirs, "we had the uncanny feeling that we were cut off from our allies."1 Nasser, according to M. H. Hayka1, became aware of AngloFrench military preparations through his contacts with EOKA eiements in Cyprus and with members of the British Labor Party. 2

On October 15, American reconnaissance planes revealed that Israel was mobilizing and that she had sixty French Mystere warplanes Instead of twelve sold earlier to her by France with American approvai. 3 President Eisenhower sent a personal message to the Israeli Premier David Ben-Gurion with the Israeli Ambassador to the United States Abba Eban. On October 25, Jordan, Egypt, and Syria announced the conclusion of a pact to increase their military cooperation and to place their armed forces under Egyptian command in case of war with Israel. Israel continued her military buildup. On October 27, the State Department forwarcled a cable from President Eisenhower to Premier Ben-Gurion expressing "concern at reports of heavy mobilization on your side... I renew the plea.. that there be no forceable initiative on the part of your government which would endanger the peace. 14

${ }^{1}$ Eisenhover, Waging Peace, 1956-1961, p. 56.

2al-Ahram (Cairo), September 24, 1971.

$3^{3}$ France had actually "delivered no fewer than seventy-five of the latest French Mystere fighter aircraft" by October 13. See Nutting, No End of a Lesson, p. 88 .

${ }^{4}$ Eisenhower, Waging Peace, 1956-1961, p. 69. 
On October 28, while Israel gave an order for general mobilization of her reserves, her Ambassador in Washington told American officials that those were purely defensive measures. But the United Staces had some indication that Israel and France were cooperating. That same day another cable was sent to Ben-Gurion urging him "to do nothing which would endanger the peace." 1

Washington, a11 the while, had assumed that Israel was preparing to attack Jordan. Instead, her army struck in Sinai on October 29. Late that day, while it still was unclear what the Israeli objective was, the White House issued a statement to the effect that the United States was determined to carry out her pledge of supporting the victim of aggression in the Middle East under the terms of the 1950 Tripartite Agreement. 2 Until the next day, October 30, the United States govermment continued to have a "lack of clear understanding as to what exactly was happening in the Suez area," says Prisident Eisenhower, "due to the break in our communications with the French and British. We were in the dark about what they planned to do."3

It soon became clear, however, that Israel's action was part of a general plan in collusion with France and Britain to achieve separate aims through joint action. 4 British and French military

$1_{\text {Ibid., P. } 70 .}$

2Ibid., p. 73 ; Current Documents, 1956, p. 646.

${ }^{3}$ Eisenhower, Waging Peace, 1956-1961, p. 75; Nutting, No End of a Lesson, Pp. 110-13.

4Michae1 Reisman, The Art of the Possible: Diplomatic Alternatives in the Middle East (Princeton, N.J.: Princeton University Press, 1970), PP. 8-9. 
planners went to work on plans for a military operation against Egypt in the first week of August. Plans for Operation "Musketeer" were submitted on August 8 and accept ad first by Prime Minister Eden on August 10, and then by the French Prime Minister Mollet. The Operation was to begin in mid-September, roughly six weeks from the time planning began. 1

The London Conference, which commenced on August 16, did not keep the British and French from going ahead with their preparations for war. American U2 reconnaissance aircraft and U.S. forces in France became aware of those preparations. British and French subjects were told by their respective governments to begin leaving Egypt, Jordan, Syria, and Lebanon. To Loy Henderson, the American member of the Menzies Mission, Eden said before he left for Cairo, "We are determined to secure our just rights in Suez, and if necessary we will use force, because I would rather have the British Empire fall in one crash than have it nibbled away as it seems is happening now." 2

Therefore, when the Menzies Mission left for Egypt on September 1, it was clear to both Egypt and her friends that the Anglo-French threat to use force was imminent. President Eisenhower was prompted to write Prime Minister Eden on September 2,

I am afraid, Anthony, that from this point onward our views on this situation diverge. As to the use of force or the threat of force at this juncture.. . nilitary preparations and civilian evacuation exposed to public

1Thomas, The Suez Affair, p. 68 . ${ }^{2}$ Finer, Dulles over Suez, p. 192. 
view seem to be solidifying support for Nasser. . . . I regard it as indispensable that if we are to proceed solidly together to the solution of this problem, public opinion in our several countries must be overwhelmingly in its support. I must tell you frankly that American public opinion flatly rejects the thought of using force, particularly when it does not seem that every possible peaceful means of protecting our vital interests has been exhausted without result.1

Eden says in his memoirs that he found this letter disquieting and disturbing. He wrote back on September 6,

I can assure you that we are conscious of the burdens and the perils attending military intervention . . . We have many times led Europe in the fight for freedom. It would be an ignoble end to our long history if we accepted to perish by degrees. 2

On September 11 Eden received a more disquieting letter, this

time from Marshal Bulganin of the Soviet Union. He wrote,

Britain is demonstratively concentrating her troops in Cyprus, in the neighborhood of the Suez Canal area. French military formations, too, have been landed on Cyprus. Other military measures have also been taken, aggravating the tension. All this is accomplished by public official declarations of the readiness of Britain and France... to begin hostilities against Egypt if she refused to place the Canal under foreign administration. 3

Bulganin then warned,

smal1 wars can turn into big wars. . I must te11 you, Mr. Prime Minister, that the Soviet Union, as a great power interested in the maintenance of peace, cannot hold aloof from this question. 4

Marshal Bulganin wrote Eden again on September 28 . Once more he warned,

1Eisenhower, Waging Peace, 1956-1961, p. 667, Appendix C.

2Eden, Ful1 Circle, p. 521.

3Thomas, The Suez Affair, pp. 184-185, Appendix II.

4 Ibid., pp. 186-87. 
My colleagues and I want to stress once again that the policy of war threats and of attempts to interfere in the domestic affairs of Egypt is creating a threat to peace in the Near and Middle East and is fraught with dangerous consequences. Any attempt to carry ont one plan or another through the use of force against Egypt means to set oneself in opposition to the majority of countries, including states the security of which is directly affected by the events in this area and which cannot remain indifferent when it is a matter of a breach of the peace, a matter of aggression. 1

Six days before Israel struck on October 29, Bulganin wrote Eden a relatively friendly letter reflecting his satisfaction with what had been accomplished at the United Nations. The letter stated that,

recourse to negotiations through the Security Council has already yielded initial fruit . . attempts to settle the Suez problem in any other fashion cannot facilitate the attainment of the necessary area of agreement and are pregnant with dangerous consequences. 2

The D-Day of September 15 and 16 was changed to September 26 and then to October $8, b$ fore it finally bacame October 29. Contacts with Israel regarding joint military action against Egypt began in early September. Prime Minister Mollet of France, however, is believed to have suggested collaboration with Israel as early as July 27, but Prime Minister Eden rejected his suggestion at that time. Toward the end of September, rumors went out that Israeli and French officials were having secret meetings. In fact, France began to supply Israel with almost any military equipment she wanted as early as the first week of August. General Moshe Dayan,

$1_{\text {Ibid., P. } 192 .}$

${ }^{2}$ Ibid., p. 195. 
the Israeli Chief of Staff then, knew of Operation "Musketeer" on September 1, and also knew that Nasser withdrew his forces from Sinai because of the Anglo-French threat. 1

In coordinating plans with Israel for the military operations against Egypt, the French suggested a date for the Israeli attack close to the election date in the United States, so President Eisenhower would not risk opposing Israel for fear of losing the Jewish vote. Starting September 10, Israel began her diversionary attacks against Jordan. By September 17, General Dayan and his staff had already begun studying plans for the capture of Sinai. On September 21, those plans were approved by the French, At that stage, Eden seems to have come a long way in accepting the idea of Israeli participation in the campaign.

Eden gave his final approval of the French plan on October 16 during a meeting in Paris between the British and French Prime Ministers and Foreign Secretaries. This meeting was preceded by another in London on October 14, during which Eden gave tentative approval of the plan. In fact, Pinau and Lloyd met Ben-Gurion outside Paris at Sevres on October 22 to assure him of their governmenits's commitment to the plan. "For Israel to move at a11," says Hugh Thomas, "Ben-Gurion wanted a written agreement, signed by all three countries, together with the presence at the final discussion of a responsible British Minister."2 By October 25, Ben-Gurion

${ }^{1}$ Ibid., pp. 84-86; Nutting, No End of a Lesson, pp. 56-57. 2Thomas, The Suez Affeir, p. 112 . 
got what he asked for and gave the green light to General Moshe Dayan on the same day. ${ }^{1}$ The following is Anthony Nutting's comment on this agreement:

Our traditional friendships with the Arab world were to be discarded; the policy of keeping a balance in arms deliveries as between Israel and the Arab States was to be abandoned; indeed, our whole peace-kceping role in the Middle East was to be changed and we were to take part in a cynical act of aggression, dressing ourselves for the part as firemen or policemen, while making sure that our fire-hoses spouted petrol and not water and that we belaboured with out truncheons the assaulted and not the assaulter. And all to gain for ourselves guarantees for the future operation of the Suez Canal which had only a day or so before been substantially gained in Lloyd's negotiations with Fawzi in New York.

Israel depended on Britain and France for equipment, supplies, and air cover for her initial attack. The final decision was that Israel would attack on the 29th of October. England and France would issue an ultimatum to both Israel and Egypt to cease hostilities and withdraw to within ten miles of the Canal, or else they would intervene to separate them and protect the Canal. ${ }^{3}$ The Israeli military operation was named "Kadesh." France was to provide an "umbrella" of French fighters to protect Israeli cities and to parachute food, supplies, and ammunition to the advancing Israeli forces. Thirty-six hours after the beginning of the Israeli attack, British bombers were to begin bombing Egyptian airfields and military

${ }^{1}$ Moshe Dayan, Diary of the Sinai Campaign (New York: Harper \& Row, 1966), .60.

${ }^{2}$ Nutting, No End of a Lesson, p. 94; see also, Michael Adams, Suez and After: Year of Crisis (Boston: Beacon Press, 1958), p. 8 i.

3Nutting, No End of a Lesson, pp. 90-109; Thomas, The Suez Affair, pp. $86-1 \overline{11}$. 
installations. ${ }^{1}$ On October 25, General Moshe Dayan noted in his diary,

Our forces will go into action at dusk on 29 October 1956, and we must complete the capture of the Sinai Peninsula within seven to ten days. The decision on the campaign and its planning are based on the assumption that British and French forces are about to take action against Egypt. According to information in our possession, the Ang10-French forces propose to launch their operations on 31 October 1956. Their aim is to secure control of the Suez Canal Zone, and for this they will need to effect a sea landing or an air drop with, no doubt, suitable air cover. ${ }^{2}$

President Eisenhower claims that he had no knowledge of the Anglo-French-Israeli plans. The CIA and Allen Dulles, who had gathered sufficient information about the military preparations of these powers, apparently withheld it from him. As Israel attacked on October 29, thirty-six French war planes flew to Israe1. Other French planes dropped food and arms to Israeli paratroops at Mitla in Sinai. Not yet aware what exact1y was happening, President Eisenhower cabled Prime Minister Eden on October 30 expressing concern and astonishnent at the British Ambassador's unsympathetic attitude toward Washington's intentions of taking the case of Israel's military action against Egypt to the United Nations and his unwillingness to allow any action to be taken against Israel. Referring to the 1950 Tripartite Declaration, the cable stated that the United States was bound by that agreement and expected Great Britain to abide by it too. "A11 this development, with its possible consequences," concluded President Eisenhower,

Thomas, The Suez Affaix, pp. 112-15.

${ }^{2}$ Dayan, Diary of the Sinai Campaign, pp. 60-61. 
including the possible involvement of you and the French in a general Arab war, seems to me to leave your government and ours in a very sad state of confusion, so far as any possibility of unified understanding and action are concerned. It is true that Egypt has not yet formally asked this govermment for aid. But the fact is that if the United Nations finds Israel to be an aggressor, Egypt could very well ask the Soviets for help--and then the Mid East fat would really be in the fire. 1

\section{DIVIDED ALLIES, UNITED ENEMIES}

As planned, an Anglo-French 12-hour ultimatum was issued October 30 to both Egypt and Israel to stop fighting, to withdraw to within ten miles of the Canal, and to accept the temporary occupation by Ang1o-French forces of the Canal Zone. If at the expiration of the 12 hours Egypt and Israel had not complied "we would intervene in such strength as necessary to secure compliance."2 Israe 1 accepted the ultimatum; Egypt rejected it. When the attack began, it did not appear like it was for the purpose of just separating the combatants or occupying key posttions at the Canal. Hundreds of bombers from Malta and Cypius converged on Egypt and began a 48-hour bombardment of ports, airfields, railways, radio towers, and communication centers. To the American government, Prime Minister Mollet said, "If your government was not informed of the final developments, the reason . . was our fear that if we had consulted it, it would have prevented us from acting." 3

${ }^{1}$ Eisenhower, Waging Peace, 1956-1961, p. 76 .

2Nutting, № 테 of a Lesson, p. 194, Appendix VIII.

${ }^{3}$ Eisenhower, Waging Peace, 1956-1961, p. 77; see a1so, Nutting, № End of a Lesson, p. 163. 
On the same day, the United States had requested a meeting of the Security Council "to consider steps to be taken to bring about th: immediate cessation of military action by Israel against Egypt." 1 The British and French used their veto power to defeat two resolutions (one by the United States and the other by the Soviet Union) aimed at condemning the use of force and calling on Israel to withdraw from Egyptian territory. Soon after the ultimatum was issued, the United States warned England and France against the occupation of positions at Suez.

Up to October 31, the Israeli forces were held up quite well by the Egyptians at Mitla and Abu Aweig1ia. But when the Ang1oFrench attack began on October 31 , Nasser ordered a general withdrawal from Sinai to concentrate defenses around Cairo. Syria's requests to open a northern front against Israel were discouraged by Nasser. Instead, the Syrians blew up the Iraq Petroleum pipelines. 2

On November 2, Secretary Dulles spoke before the United Nations General Assembly. "I doubt that any delegate ever spoke from this forum with as heavy a heart as I have brought here tonight," said Dulles,

${ }_{1}^{1}$ U.S., Department of State, Bulletin, XXXV (November 12,
1956), 748 .

2 Thomas, The Suez Affair, p. 130; Seale, Struggle for Syria, p. 262; Rabih Lutfi Jumah, Sahg al-'Udwan al-Thulathi (Cairo: al-Dar al-Qamniyah 111-Tiba'an wa-a1-Nashri, 1962), pp. 111-16; Samir Sadiq, Qissat al-'Udwan al-Thulathi 'ala Misr (Cairo: al-Dar al-Qawmiyah 1il-Tiba'ah wa-al-Nashr, 1961), pp. 134-35. 
We speak on a matter of vital importance, where the United States finds itself unable to agree with three nations with whom it has ties, deep friendship, admiration, and respect, and two of whom constitute our oldest, most trusted and reliable allies. 1

On November 5 , the White House issued a statement rejecting a Soviet proposal to jointly use force in Egypt to restore peace. ${ }^{2}$ Former Soviet Prime Minister Nikita Khrushchev says that this note was meant to expose "the hypocrisy" of President Eisenhower's "pub1ic statement condemning the attack against Egypt." Mr. Khrushchev quotes President Eisenhower as saying, "This is incredible! Can the Russians be serious? To think that we would join them against Britain, France and Israel! It's incredible!" Khrushchev concludes,

So our note had done exactly what it was supposed to do; it had put the lie to the Americans' claim of being fighters for peace and justice and nonaggression. They may have been fighters in words, but not in deeds, and we had unmasked them. 3

He then goes on to argue that England and France did not fear America's condemnation of their action, but had to pay serious attention to . Russia's "stern warning." 4

It is true that violent notes were received by France, Britain, and IsraeI from the Soviet Union on November 5. The note to Israel questioned "the very existence of Israel as a state" as a result of 751.

${ }^{1}$ U.S., Department of State, Bulletin, XXXV (November 12, 1956),

${ }^{2}$ Ibid., (November 19, 1956), 795-96; see text of November 5 Sovie: Note in Ibid., 796.

Khrushchev, Khrushchev Remembers, PP. 434-35.

${ }^{4}$ Ibid., p. 436. 
her attack against Egypt. 1 The notes received by Britain and France threatened the use of "every kind of modern destructive weapon"2 against them. Mr. Khrushchev, however, neglects to point out what America's strong opposition to the assault on Egypt was declared on the first day of fighting and that Russia's missile threat 3 did not come until it became clear on whose sice America stood. Until he went to the hospital on November 3, Secretary Dulles led the United States in opposition to the three-power attack on Egypt. During Dulles's illness, President Eisenhower took direct charge of the matter and spoke to Prime Minister Eden on the phone demanding an immediate cessation of hostilities. Washington kept up its pressure on London by not coming to its rescue when the run on the pound sterling in international money markets was having devastating effects on Britain's resolve to continue the war. It is believed that the American pressure on sterling was more effective than Russia's threat to attack Britain and France with Rockets. 4

United States opposition to the use of force in Egypt, however, Secretary Dulles is reported to have told French Foreign Minister Pineau, was

1Quoted in Avigdor Dagan, Moscow and Jerusalem: Twenty Years of Relations Between Israel and the Soviet Union (New York: AbelardSchuman, 1970), P. 108 .

2Quoted in Thomas, The Suez Affair, p. 142.

${ }^{3}$ It is presumed that this threat was made upon the recommendation of President Shukri al-Quwatly of Syria, who was then in Moscow on a state visit. See Thomas, Suez Affair, p. 142; Seale, Struggle for Syria, pp. 261-62.

${ }^{4}$ Drummond, Duel at the Brink, pp. 174-75. 
not based on a desire to keep Nasser in power... the United States did not accord preference to Nasser or the Arabs over Britain and France, its traditional and great allies. He noted that neither cultural nor racial ties bound the United States to the Arabs. But, he said, the use of force against Egypt could only result in rallying support behind Nasser. 1

The basis for United States opposition was mainly moral and practical. Practical, because the United State believed that force could not defeat the West's enemies or settle the problems at hand. "In al1 recent troubles in the Middle East," said President Eisenhower, "there have, indeed, been injustices suffered by all nations involved. But I do not believe that another instrument--war--is the remedy for these wrongs." The moral basis of the American stand was also explained by President Eisenhower. He says,

we sense a special concern for the fate and fortune of those 700 million people in 18 nations who have won full independence since World War II. We know and respect both their national pride and their economic need. Here we speak from the heart of our heritage. We, too, were born at a time when the tide of tyranny running high threatened to sweep the earth. We prevailed and they shall prevail. . . . We cannot and we will not condone armed aggression, no matter who the attacker and no matter who the victim. We cannot, in the world any more than in our own nation, subscribe to one law for those opposing us, another for those allied with us. There can be only one law, or there will be no peace. 2

\section{DEFEAT INTO VICTORY}

Nasser won a conclusive victory in 1956. A cease-fire resolution, introduced by Secretary Dulles on November $I$ to the United Nations

${ }^{1}$ Ibid., pp. 174-77.

2 Time, November $12,1956$. 
General Assembly, 1 was approved by a vote of 64 to 5 on November 2.2 "This vote," commented Vice President Richard Nixon on the same day, constituted a world-wide vot of confidence, the like of which has never been known before. . . For the first time in history we have shown independence of AngloFrench policies toward Asia and Africa which seemed to us to reflect the colonial tradition. That declaration of independence has had an electrifying effect throughout the world. 3

The November 2 resolution was followed by two others, adopted by the United Nations General Assembly on November 4. The first was a proposal, advanced by Mr. Lester Pearson of Canada, to organize and dispatch a U.N. Peace Force to separate between Egypt and Israel and restore free traffic through the Suez Canal. This was adopted by a vote of 57 to 0 . The second, adopted by a vote of 59 to 5 , was another cease-fire resolution sponsored by 19 nations. The hostilities finally ended on November 6. The United States fully supported the United Nations in its efforts to restore peace to the area. The invading forces eventually withdrew from Egypt; Nasser's govermment was paid compensations for the damage caused to its country; and the Canal remained under sole Egyptian control. 4 The pressure on England, financial, economic, and political, had its effect, no doubt. 5 But world opinicn seems to have been

${ }^{1}$ Current Documents, 1956, p. 656.

2Ibid., pp. 657-58.

${ }^{3}$ Quoted in Finer, Dulles over Suez, p. 397.

${ }^{4}$ Ibid., pp. 403-10; Thomas, The Suez Affair, pp. 134-49; Nutting, № End of a Lesson, pp. 168-71.

${ }^{5}$ Ibid., pp. 137-40, $144-47$. 
the most effective force. During October, in conversation with Tom Iittle, then Middle East Correspondent of the London Observer, Nasser said, "I don't intend to fight them $\bar{L}_{\bar{i}}$ e., Britain and France $/$. I intend to stand back and wait for world opinion to save ne."1

It was moral force, no doubt, that brought the military operations to a halt. "At Westminster the British House of Commons was suspended in an uproar," says Harry Hopkins,

of a sort hardly heard for a generation. The basically moral issue of "Suez" split the British with a violence and bitterness rare in England's history. And the revulsion and anger of many in Britain was swollen by the sense of outrage in the Commonwealth. "In the Middle of the twentieth century," wrote the leading Pakistan newspaper, Dawn, "enlightened countries like Britain and France have suddenly tumed the clock back hundreds of years . . . and decided to act as self-chartered libertines of the gun and bomb. ${ }^{2}$

It was Nasser who detected, understood and used this moral force--the new weapon of the "Third World." The anxiety and fear felt by Prime Minister Eden were testified to by Anthony Nutting, Minister of State at the Foreign Office, who resigned on October 31 , over the Suez issue, following the issuance of the ultimatum to Egypt and Israel. Nutting says that the censure of the United States and the Commonwealth and the United Nations pressures threatened to isolate Britain. 3 Nutting says, "I know that he $\overline{\bar{E}}$ den $\bar{l}$ felt very deeply the censure wich he had brought upon hims elf from the United States and the Commonwealth."

${ }^{1}$ Quoted in Hopkins, Egypt, the Crucible, p. 184.

2Ibid., pp. 184-85; see also, Adams, Suez and After, pp. 4-5.

3utting, No End of a Lesson, pP. 124-39.

${ }^{4}$ Ibid., pp. 133-34. 
According to Harry Hopkins,

Suez has a claim to be considered the first war in modern history to be stopped in its tracks by the force of world opinion. It may be argued that Nasser was merely benefitiing from an accident or lucky gamble. But it seems more likely that this man, so very much of his time and place, instinctively understood what was neglected by more sophistocated politicians, the power and character of the ideas at work in the world of the $1950^{\prime} \mathrm{s}$, and this, and his nerve in mobilizing them in the construction of a sort of global morality drama of unprecedented dimensions should ensure him, if nothing else does, a place in history. 1

\section{THE AFTERMATH}

While Nasser acknowledged the value of America's support during the crisis, he could not forget her other actions before, during, and after the crisis. Those included America's refusal to supply Egypt with lubricating oils and parts for her U.S.-made machinery, her withdrawal of the offer to help build the Aswan High Dam, her refusal to sell the needed wheat to feed the Egyptian people, her cancellation of distribution of CARE lunches to Egypt's school children, and her denial of Egypt's requests for medicines to treat the victims of the Suez war. These were actions which left deep scars. "The Soviets responded almost immediately," to Egyptian requests for wheat and pharmaceuticals, says Miles Copeland, "when made to them." 2

In doing so, the United States drove Nasser further into the arms of the Soviet Union and made the new Soviet-Egyptian friendship

1Hopkins, Egypt, the Crucible, p. 185.

${ }^{2}$ Cope1 and, The Game of Nations (New York), p. 214. 
more acceptable to the Egyptian people. For years Egypt sought American assistance. The offer to help build the Dam came only after Nasser made the arms deal with Russia. Nasser pointed out his main difficulty with the United States in an answer given to American newsmen who asked if he would be willing to meet with President Eisenhower to try and resolve his area's problems. "Of course... I am ready to do anything," he answered, "to serve the cause of peace. But I cannot answer directly because of my experience with your state Department. They may make statements to humiliate Egypt by rejecting this as before."1 When asked what his reaction was to discontinued CARE food distribution in Egypt, Nasser replied, "I had no reaction. After our experience with the High Dam, I learned that we must depend on ourselves. $" 2$

The Suez crisis brought to an end the collective responsibility of the United States, Great Britain, and France under the Tripartite Declaration of 1950 to protect their common interests in the area. Britain and France came out of the crisis seriously humiliated and stripped of what influence or power they had in the region. The United states was left face-to-face with a growing Soviet presence and a challenge that seriousiy threatened western interests. 3

Nasser continued to call for a just solution of the Palestine problem and to encourage activities aimed at discrediting France and

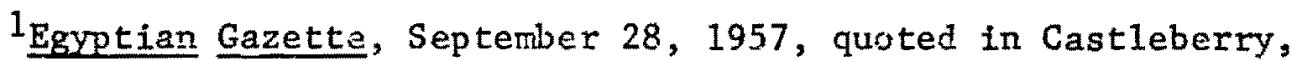
"The Arabs' View of Postwar American Foreign Policy," $21 \mathrm{n}$.

2Ibid.

3iurewitz, "Soviet-Anerican Rivalry in the Middle East," 10. 
Britain, their allies in the Middle East, and the Baghdad Pact. Ties between him and Syria and the Soviet Union were growing closer by the day. His anti-West pclicies became mcre acceptable in the Arab world after Suez; therefore more successful. "The blood which flowed in Egypt," says P. V. Milogradov, "and the barbarous destruction of Port Said have finally opened the eyes even of those who in one way or another still believed in the 'civilizing mission' of the imperialist powers in the East."1

American continued to think that Nasser "was an obstacle to the United States alliance system and too friendly to the Soviet Union."2 As the year 1957 began and the United States assumed full responsibility for the protection of Western interests in the Middle East, Nasser was "more and more" viewed as an "enemy of the West," 3 and the signs pointed to an inevitable head-on collision between him and the United States.

${ }^{1}$. V. Milogradov, in E. M. Zhukov, "The Eisenhower Doctrine and U.S. Foreign Policy," International Affairs (Moscow, February, 1957), p. 74.

${ }^{2}$ Richard H. Nolte, "U. S. Policy in the Middle East," in Georgiana G. Stevens, ed., The U. S. and the Middle East (Englewood Cliffs, N.J.: Prentice-Ha11, 1964), p. $1 \overline{64 .}$

${ }^{3}$ Campbe11, The Middie East in the Muted Cold War, p. 7. 
CHAPTER VII

THE EISENHOWER DOCTRINE

After Suez, America, Britain's heir in the Middle East, found nerself face-to-face with Russia. The United States became the only Western power with some influence in the area not yet eroded. The Soviet Union, on the other hand, by the end of 1956, had made great gains by supporting Arab nationalism against the West. Russian arms, trade, financial and technical aid, helped cement a growing and promising Soviẹt-Arab relationship. The United States sought the same ends but followed different tactics. Russia's support of Arab nationalism meant a strategy of enlisting Arab public support and seeking those things the Arabs themselves sought. Among the things Russia sought, respected, encouraged, and supported were the Arab's wish to be neutral, their national independence, their need for various forms of aid, their economic development, their need for strong backing, and a call for an agreement renouncing the use of force in the Middle East. In the words of V. Mayevsky, "the Soviet Union supported and continues to support the principles of the Bandung Conference and . . . it is trying to build its relations with the countries of Asia and Africa on the basis of these prinaiples."1 In the face of this Soviet challenge, the Baghdad Pact proved

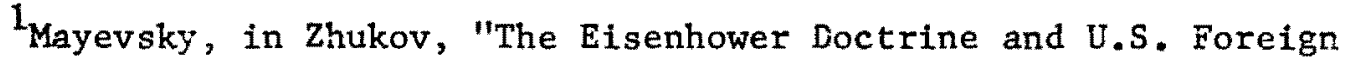
Policy," p. 70 . 
inadequate. More effective means were called for to check Russian advance. But the Eisenhower Administration did not as yet seem to have come to grips with the true nature of the political and social mood in the Arab world. There was ample evidence as to what the Arab mood was. The reaction to the Baghdad Pact was a clear indication of what the Arab world did not want. With all the efforts to make Jordan join the Baghdad Pact, public national pressure prevented King Hussein from joining 1t. The Pact had been successfully resisted and Iraq, its only Arab member, had been isolated.

When in December 1955 and January 1956 new efforts were made to draw Jordan to the Baghdad Pact, riots broke out in Amman and other Jordanian cities denouncing the Jordanian government and the Baghdad Pact. Two cabinets fell during those two months and King Hussein had to announce that he had no intention of joining the Pact and promise free elections. On March 1, 1956, he dismissed General John Glubb, the British Commander of Jordan's Arab Legion, and replaced him with Genera1 Ali Abu Nuwwar, a pro-Nasser officer. Hussein dissolved the Parliament in June and free elections were held on October 21. The elections brought in a parliament with a clear pro-Nasser major1ty. Premier Sulayman al-Nabulsi headed a government that was composed mainly of Ba'thists and Nationa1 Socialists. By January 1957, Jordan's annual Britisin subsidy had been replaced by an annual sum of $\$ 35$ million to be paid by Saudi Arabia, Egypt, and Syria. 1

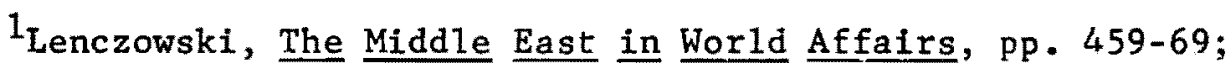
Emi1 Lengye1, The Changing Middle East (New York: John Day Co., 1960), pp. 210-13; Copeland, The Game of Nations (New York), pp. 217-19. 
During the Suez crisis, pro-West Arab regimes joined Syria in a great show of solid support for Egypt. But the crisis and its consequences seriously undermined the pro-West policies of those regimes. Thus the power "vacuum" recognized by the West, but the existence of which Nasser strongly denied, was felt by governments friendly to the West. Lacking popular support, those regimes looked and found no significant crutch powerful enough to lean on. Weak and slakey, they hoped the United States would quickly step in and provide sufficient backing and support against the progressive national forces threatening to sweep them away. "Nasser could only hope," says Miles Copeland, "that we come up with something as embarrassing to the blacklegs as the Baghdad Pact had been. . . We did."I

Since Nasser did not cooperate with the West in the formation of a Western-sponsored defense system, the United States concluded that he should be isolated from the rest of the Arab world and, perhaps, eventually brought down. According to Round Table,

The Egyptians are not far off course in suspecting that the United States is preparing--by means of the Eisenhower Doctrine and by such diplomacy as the invitations Washington extended to both King Saud of Saudi Arabia and Prince Abdul Ilah of Iraq--to isolate Egypt if it remains intransigent. 2

Nasser, on the other hand, sought to achieve further victories for his policies. His main objectives were uniting the Arab world under one lendership, following one Arab foreign policy, ashieving true and complete independence for all Arabs, and forming a purely

IIbj.d., p. 215.

2"The Eisenhower Doctrine: Beginnings of a Middle East Policy," 146. 
Arab defense system. Unt11 1956, Nasser had the upper hand and had generally won every round against Britain, Nuri al-Said of Iraq, and the United States. The fact that he was able to keep Syria on his side was, no doubt, the key to his success. His triumph at Suez gained him all the popular Arab sentiment and support he ever hoped for.

Russia being his principal supporter after 1955, he could not allow his fellow Arab states to join an alliance afmed at her. Besides, he could not see how Arab countries, incluaing his own, could permit an independence just won to be jeopardized by American overlordship. Most importantly, he could not tolerate any pressure on Syria, which might weaken his hold on her and increase the ranks of his Iraqi rival, resulting in a shift in the area's balance of power in favor of his enemies.

\section{THE DOCTRINE INTRODUCED}

On January 5, 1957, President Eisenhower proposed to the American Congress the adoption of a resolution authorizing him to use the United States armed forces in the Middle East "against covert armed aggression from any nation controlled by Internationa1 Communism."1 The proposal reflected a fear in Washington of a Soviet bid to fill the supposed power "vacuum" in the Middle East through an armed attack or by internal subversion. According to L. Brent Boze11, $1957), 86$.
U.S.

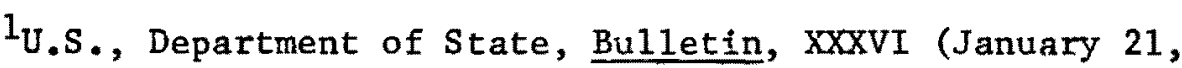


the President gave the impression "that the country has greater reason to fear Communism than to fear war." What he was asking for was "authority to resist Soviet aggression, or not to resist it, as he sees fit."1

Secretary Dulles seems to have been convinced that the Soviets lacked moral restraint, that they had the capacity for armed attacks, and that the Middle East presented too great a temptation for them. On January 14, 1957, he told a joint session of the Foreign Relations and Armed Services Commission of the Senate, "I can assure you that the leaders of International Communism will take every risk that they dare in order to win the Middle East." 2 This was the danger that Secretary Dulies could see. He felt that the Russians were not likely to let this opportunity slip by. "Soviet ground, naval and alr forces," said Dulles,

are stationed in the areas adjacent to the Middle East-Bulgaria, the Black Sea, the Ukraine, the Caucasus and Central Asia. These Soviet forces are of a size, and are so located, that they could be employed at any time with a minimum of warning. 3

It is this feeling of real darger that made the Eisenhower Administration take the urgent and hasty measures embodied in the E1senhower Doctrine proposals. By March 9, the proposa1s were already approved by the Congress and signed by the President. 4 A fund of

$1_{L}$. Brent Boze11, "The Mideastern Policy," National Review, III (January 19,1957$), 56-57$. 174.

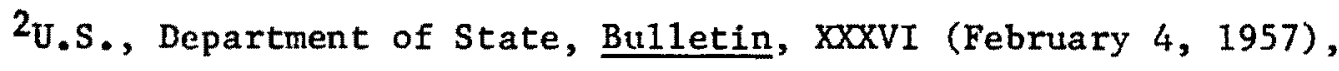

3 Ibid., 170.

${ }^{4}$ Ibid. (March 25, 1957), 481. 
$\$ 200,000,000$ was provided and the United States promised economic and military assistance to any Middle Eastern state desiring protection unciar the tecms of the Eisenhower Doctrine. To line up adherents, President Eisenhower appointed Mr. James P. Richards, who left for the Middle East on March 12.1 on March 22, the United States announced her intention to join the Military Committee of the Baghdad Pact. ${ }^{2}$ The Eisenhower Doctrine was devised to meet the threat of internal subversion and external outright aggression by Soviet communism. Its aims and objectives were those of the 1951 defense proposals with slight modifications. The preservation of the status quo continued to be a fundamental objective of American policy in the Middle East. The Eisenhower Doctrine differed from the Truman Doctrine mainly in aspects meant to suit the temper of the Middle East at the time. The weakness of the Truman Doctrine was in the fact that it could not possibly be enforced to its fullest. In retaliating, the United States had to pick and choose from among aggressions and subversions committed by the communists. Some were met militarily, some verbally and diplomatically. These facts were known to both the United States and the Soviet Union. The Eisenhower

${ }^{1}$ Ibid., 482; Ibid. (April 1, 1957), 526.

2 Statement made by President Eisenhower's Press Secretary in a news conference during the meeting between President Eisenhower and Prime Minister Harold Macmillan at Tucker's Town, Bermuda, March 22, 1958. See Current Doctiments, 1957 (Washington, D.C., Government Frinting Office, 1961), p. $7 \overline{71 ;}$ see a1so, M. Perlman, "Withdrawal in East--Retreat in West," Middie Eastern Affairs, VIII (May, 1957), 178. 
Doctrine was considered necessary so the Soviet Union could be specifically informed that the Middle East was an area the United States would, if necessary, use military force to defend. Such action, however, would be dependent upon the invitation of the country concerned. The latter condition was not part of the Truman Doctrine. 1

\section{THE DOCTRINE'S DRAWBACKS AND DIFFICULTIES}

It is not known who originated the idea of the Eisenhower Doctrine. Miles Copeland suggests that it might have been Secretary Dulles or Assistant Secretary Bill Rountree. He recalls, clearly. . that neither the "Middle East Policy Planning Committee" (State, Defense, and CIA) nor the regular staff of the Bureau of Near Eastern and African Affairs had anything to do with it. . . in the light of extant intelligence on the Arab world it made no sense at all. As I remember, the Middle East hands were fairly unanimous about this. When the CIA representative on the MEPPC was asked, "Would you fellows like to sent someone along on the mission that's going to explain it to Arab chiefs of state?" he replied, "We can't afford to associate ourselves with every lunatic scheme that comes along." 2

The Doctrine was criticized for being silent with regard to the only kind of aggression the Arabs really feared--aggression by a non-communist country. Memories of the 1956 invasion of Egypt by Britain, France, and Israel, were still fresh in Arab minds. It said nothing about a million idle, miserable and bitter Palestinian refugees, whose problem constituted the single most explosive issue

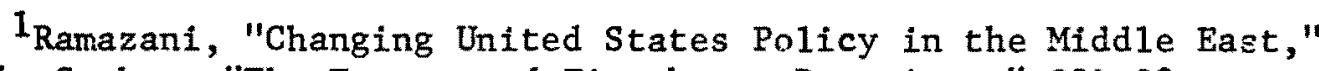
373-74; Graber, "The Truman and Eisenhower Doctrines," 331-32.

2Copeland, The Game of Nations (New York), p. 216. 
in Middle Eastern affairs, and who sadly waited for the institution of justice. What the Doctrine did say, however, offended the Arabs and stirred resentment in them. References to the existence of a power "vacuum" in the Middle East exposed Arab military weakness and intensified their feeling of inferiority. The call to "stand up and be counted," among America's friends or enemies insulted them and violated their popular ideal of "positive neutrality."

Ever since the policy of "positive neutrality" was announced by Arab nationalists and adopted by most Arab states, Secretary Dulles was determined to make it ineffective. Nasser and the Arabs knew that neutrality could not be maintained unless they abstained from pacts, alliances, conditional agreements, and political strings. "The sharply anti-communist character of the Eisenhower Doctrine:" says V. Mayevsky,

wil1, its authors calculate, confront each Middle Eastern country, and also every other neutral country, with a dilemma: either support the doctrine and adhere to the anti-communist bloc, or not support it and be counted among America's enemies, with all the consequences flowing therefrom. In essence, the doctrine aims at putting an end to the neutral policy pursued by many Eastern countries, destroying the Bardung concept and the principle of peaceful co-existence and drawing the Asian and African countries into the "cold var."1

Therefore, the Doctrine, which seemed simple and straightforward to its authors, created all kinds of complications to the chiefs of Arab states. "By endorsing the Doctrine," observes Patrick Seale, "an Arab state would be forced to make a public

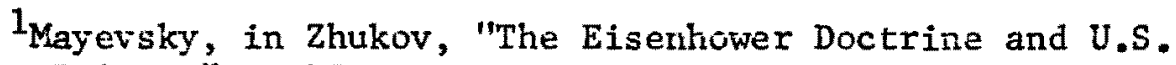
Foreign Policy," p. 70. 
stand not only against Russia but also against an Arab neighbour."I And that was what the Arab states, even pro-West ones, wanted to avoid for fear of public censure and incrimination. By most Arabs, the Eisenhower Doctrine was seen "as an American effort," says Max Thornburg,

to place the next war's battlefield in the Middle East Instead of nearer home, to replace British with American "imperialism," to seduce Middle East governments into bartering sovereignty for American aid, and to turn the Middle East countries against Communists because Americans feared Communism as a threat to their own way of life. 2

As far as Nasser was concerned, his hope, that the United States would come up with a plan as embarrassing to his pro-West opponents as the Baghdad Pact, was more than fulfilled. But "the only aspect of the Eisenhower Doctrine that gave him pause," says Miles Copeland,

was the assignment of Congressman James P. Richards to take the happy news to President Chamoun, King Hussein and the others. The choice of an emissary who could be presumed to have about as much comprehension of Arab affairs as Nasser had of pop art greatly puzzled Nasser, and made him suspect that the project had some Machiavillian twist that was going over his head. "The genius of you Americans," he once told me, "is that you never make clear-cut stupid moves, only complicated stupid moves which make us wonder at the possibility that there may be something to them wo are missing." 3

Through the Eisenhower Doctrine the United States was placed in the position of bearing full responsibility for Western interests

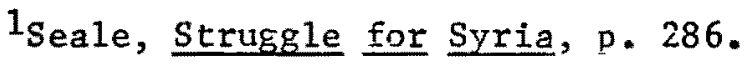

${ }^{2}$ Thornburg, People and Policy in the Middle East, p. 200.

${ }^{3}$ Copeland, The Game of Nations (New York), p. 216. 
in the area. The enemy to be fought was, of course, communism. The enemy became unidentifiable, however, as it disappeared into the tar.oled web of Arab politics. The United States found it increasingly difficult to differenciate between communists, Arab nationalists, Ba'thists, and Nasserists. By branding all these groups as enemies, the United States drove Arab nationalists further into Soviet arms. There was no question about the popularity of the Soviet Union with the Arab masses. Her support and her policies, since 1954, made a great impact on the Arab mind. Pro-Soviet sentiment was evident everywhere--in Arab press, in Arab official statements, in demonstrations and public meetings, and over radio. But this popularity was due to the fact that Russia supported Arab interests, not to ideological convictions. The Arabs praised the Soviet Union not because they were communists, but because they were nationalists, delighted over a new protector and ally. The United States overlooked this important fact. The anti-communist record of both Nasser and the $\mathrm{Ba}^{\prime}$ th Party were disregarded. The apparent cleavage between the nationalists and the communists was brought about only in opposition to Western pressures. Failing to distinguish between the nationalists and the communists, the West pushed them into each other's arms. 1

III. THE DOCTRINE IN TIE BALANCE

Syria was the first among the states of the Middle Easi to attack the basis of the new American pian. A rejection of the "vacuum" 
theory was issued by the Syrian government on January 10, 1957, only five days after President Eisenhower delivered his Doctrine meosage to the Congress. According to the Syrian statement, no power had the right to intervene in the area for any reason whatsoever; communism did not pose a threat to the Arab world; and the only dangers the Arabs could see were Zionism and the remnants of colonialism and "imperialism." "Beyond a11 doubt," declared Prime Minister Sabri al-Asali, "there is no sign whatever of international communist dangers in Syria threatening its independence, security, or freedom."1

Both Syria and Egypt saw alignment as a danger to their cherished independence. Jordan, Saudi Arabia, Syria, and Egypt, met In Cairo in early 1957 to discuss the Doctrine and come up with a unified policy toward it. King Saud tried to se11 the American point of view to his colleagues. King Hussein sided with him. Syria and Egypt took the stand

that any compromise at this juncture with the West would not only be futile since it would be an invitation for Russia to start its own militant strategy in West Asia, but it would once and for all end the prospect of Arab independence of either of the power blocs, an objective which the Arab nations had accepted at Bandung. 2

The meeting ended with a partial victory for the United States. And the possibility of winning Arab states, other than Iraq and Lebanon, to the plan was strengthened.

Attention was then focused on Syria. If she could be won over,

$1_{\text {Mirror, January } 13,1957 \text {, quoted in Torrey, Syrian Politics }}$ and the Military, p. 338.

2"The Ike Doctrine Powder Keg," Jana, IV (June, 1957), 4. 
it would mean a serious blow to Nasser's pollcies and a significant setback to his campaign against the Eisenhower Doctrine. The Richards Mission lefi no doubt that a majur objective was to isolate Syria from Egypt. By avoiding both Damascus and Cairo, Mr. Richards was seen as an agent of Washington trying to reestablish the policy of "divide and rule," to undermine the goal of Arab unity, and to Institute a new "imperialism."

Since conditions in Jordan made it impossible for Mr. Richards to visit Amman, King Hussein sent Mr. Samir Rifai, a former Prime Minister, to meet him in Beirut. Upon Rifai's return to Amman, the King dismissed his freely-elected, left-ward leaning, and pro-Nasser government. It was reported that the action was taken following an attempt to overthrow King Hussein and establish a republic. General A1i Abu Nuwwar, the Commander of Jordan's army, was accused of leading the attempted coup, arrested, and then released and allowed to go to Syria. In place of the freely-elected government, Hussein estab1ished his own authoritarian rule based on traditional and reactionary elements in his country. Soon, Hussein received King Saud's approval of his actions. To add insult to injury, Hussein demanded the withdrawa1 of Syrian troops stationed in his country since the Suez crisis. 1

The United States goverrment, uninvited and in harmony with its policy of "massive retaliation," accompanied Hussein's action by rapid fleet movements into the eastern Mediterranean, generous

${ }^{1}$ Lengye1, Changing Middle East, pp. 212-13; Lenczowski, The Middle East in Wor1d Affairs, pp. 462-69; Copeland, The Game of Nations (New York), pp. 218-19. 
promises of financial and economic assistance, and assurances of American help in defending the independence and sovereignty of Jordan. On June 29, the United States extended to Jordan a grint of $\$ 10,000,000$ in addition to ancther $\$ 10,000,000$ granted in April. ${ }^{1}$ Washington's behavior infuriated both Syria and Egypt, and made it possible for commentators to suggest that the King's action was inspired or encouraged by the United States. The presence of the Sixth Fleet in the Beirut harbor and off the Syrian coast, and the attitude of Syria's neighbors intensified the fear over what might happen to her progressive nationalist government. Writing during those tense days and weeks, Jana's correspondent said,

If the Syrian government in Damascus, by any chance, accepts the Eisenhower Doctrine which is but one step towards the Baghdad Pact, the Nasser regime in Cairo will be in danger. The Americans would have achieved what the British and the French wanted to do in Cairo by resort to arms but failed--change Nasser and bring into existence in Egypt a government which would be "amenable" to the West. 2

But Nasser was determined not to let this happen. His strong ally was Russia, whose interest was in keeping Syria out of Western defense plans.

After visiting fifteen Middle Eastern countries, including Lebanon, Iraq, Yemen, Libya, Sudan, and Morocco, Mr. Richards reported on May 27 and June 13 that all the states visited, with the exception of the Sudan and Yemen, "have endorsed the objectives" of the Eisenhower

$1_{\text {William Appleman Williams, America and the Middle East (New }}$ York: Rinehart, 1958), p. 54.

2"The Ike Doctrine Powder Keg," 4. 
Doctrine. 1

But when the Syrian crisis prompted talk in Washington of invoking the Doctrine against Syria, things began to fall apart. The call for Arab unity, in an effort to back Syria, caused existing support for the Doctrine to collapse. The Lebanese government came under pressure from opposition groups for its continued endorsement of the Doctrine; the Iraqi government wisely avoided any mention of its sympathy for it; and King Hussein, under intensive pressure from nationalist forces in his own country, kept out of it. ${ }^{2}$ Although Lebanon remained the only Arab country to retain approval of the Doctrine, she joined Saudi Arabia to lead the whole membership of the Arab League in giving assurances of support to Syria against any aggressor, no matter who it was. 3

Damascus and Cairo radios strongly attacked the Eisenhower Doctrine and the American effort to encircle and isolate Syria. The messages from Moscow were not less persuasive. In the 1ight of what was taking place, they were very convincing indeed; "we must not a11ow the enemies of peace," $\mathrm{V}$. Mayevsky's exhortation went,

to drag us into the "cold war," as they are trying so hard to do. The basis of the Leninist foreign policy of the Soviet Union was and remains peaceful co-existence, relaxation of tension and strengthening of peace throughout the world. 4

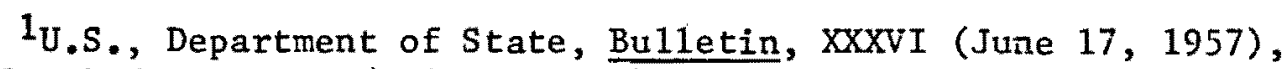
969-72; Ibid., XXXVII (July 1, 1957), 17-19.

${ }^{2}$ New York Times, October 15, 1957.

${ }^{3}$ Ibid., November 1, 1957; Ibid., November 13, 1957.

${ }^{4}$ Mayevsky, in Zkukov, "The Eisenhower Doctrine and U.S. Foreign Policy," p. 71 . 
Soviet support for Syria against the forces ranged against her continued to come loud and clear.

\section{THE DOCTRINE AND SYRIA}

In November 1956, the Iraqi conspiracy to effect a change of government in Syria was discovered and most of the West's allies in that country were destroyed. Syria's People's Resistance Forces were rapidly growing in numbers and in strength. During the Suez crisis, the news was heard of Soviet volunteers ready to come to Egypt's aid. In 1957 , those same volunteers were reported ready and willing to come to Syria's aid too. Syria's contacts and agreements with Russia and the eastern bloc increased.

Official and unofficial sources in Iraq, Lebanon, Turkey, Britain, France, the United States, and Israel, 1istened to and circulated reports of massive deliveries of Soviet military equipment and technicians, of Soviet military officers and of secret desert bases. There was very scant concrete evidence to confirm those reports, however. The Syrian government repeatedly denied such reports and assured the world that Syria was not going communist. But Syria's denials and assurances were not listened to.

Meanwhile, Syria continued to strengthen her ties with the communist bloc. In March, the Czechoslovak Techno-Export Company was awarded the contract to build the first syrian oil refinery at Homs. Ba'th-comunist cooperation grew stronger and the syrian Parliament listened to a number of anti-West speeches delivered by its only conmunist member, Khalid Bakdash, the foremost communist 
leader in the Arab world.

On August 6, Syria signed with the Soviet Union a widelyranging ecoromic and technical agreement in Koscow. On August 13, three American diplomats, accused of plotting to overthrow the Syrian regime, were expe1led. 1 When the United States government retaliated by expelling the Syrian Ambassador with one of his aides and issuing a warning to Syria, Nasser declared his ful1 and "complete support for Syria, whose 'only sin' was that 'she did not dance to the American tune." $" 2$ On August 17, Afif a1-Bizri, allegedly a communist sympathizer, became Chief of staff of the Syrian amy and a number of officers were purged. News of these events heightened tensions in Washington. The State Department concluded that a serfous Soviet attempt was underway to take over Syria. "The great question Mr. Dulles and other leaders of Western diplomacy wi11 face this week," commented the New York Times, "wil1 be whother the United States and Syria's pro-Western neighbors can tolerate a Soviet satel11te. . in the heart of the Middle East." 3

But Syria's friendship with the Soviet Union was only the natural outcome of normal and mutually beneficial relations with a powerful friend that extended help without conditions--the type of help sought by the neutralist-nationalist forces in the Arab

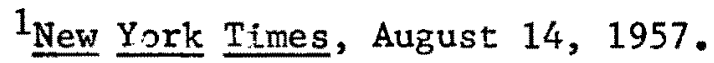

${ }^{2}$ Hopkins, Egypt, the Crucible, p. 206.

$3_{\text {New York Times, }}$ August $18,1957$. 
world. 1 The dismissal of the American diplomats was preceded by charges which cannot be dismissed as fabrications. The trials which fo.lowed revealed the facts. What actualiy foiled the plot was the fact that the Syrian army officers, with whom American officials had clandestine contacts, were loyal to the regime. They immediately reported the subject, content and intent of those contacts. It was revealed later that the former Syrian dictator Adib al-Shishakli and retired Colonel Ibrahim al-Husayni made clandestine trips to Beirut where they met the conspirators, including some leaders of the Syrian National Social Party. 2

Evidently the United States government and its Middle Eastern friends were quite anxious to replace the leftist regime in Syria at any cost and by any method that gave any hope of succeeding. It is important to note that the forces which the United States was trying to overthrow were not communist but progressive national forces, which she suspected as either being communist or communist collaborators. Even the appointment of Afif al-Bizri as Chief of Staff of the Syrian army should not have caused panic in Washington. Colonel Hamid al-Sarraj, Syria's strongman at the time, told Patrick Seale in Cairo on January 27, 1961,

Bizri's appointment had nothing to do with his supposed communist leanings (which in any case only emerged later) not with Khalid al-Azm's visit ${ }^{3}$ to Moscow. It was simply

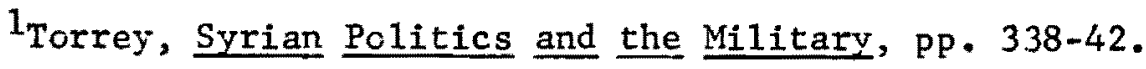

I Ibid., pp. 360-61.

${ }^{3}$ The visit during which an economic and technical agreement was concluded with the Soviet linion. 
that we had demanded from Nizam al-Din ${ }^{1}$ the dismissal of a number of senior officers implicated in Ibrahim a1-Husayni's attempted coup. Nizam al-Din refused. We then engineered his dismissal and his replacement by Bizri who seemed a non-contrnversial figure: he had no personal following in the army and was connected with none of the major factions then feuding inside the general staff. His appointinent was therefore acceptable to everyone. ${ }^{2}$

Though unwarranted, Washington's alarm caused Secretary Dulles to conduct crisis talks with President Eisenhower, with his advisers, and with the British Ambassador in Washington. At the close of these talks, Dulles concluded that there was nothing, short of force, that the United States could do to a1ter the situation in Syria. Syria's neighbcrs were asked to help determine policy in dealing with her. America's efforts were aimed at isolating Syria and encouraging "a11 anti-communist countries in the Middle East to use what pressure they can to restrain" her. 3

Syria's Minister of Defense Khalid al-Azm, though bitter about the attitude of the United States and her Middle Eastern friends, declared that Syria's foreign policy would continue to be that of "positive neutrality"; but, he warned, "we are at the outer edge of that policy; do not force us to go beyond it." 4

\section{LOY HENDERSON'S MISSION}

The United States, however, was determined, so it seems,

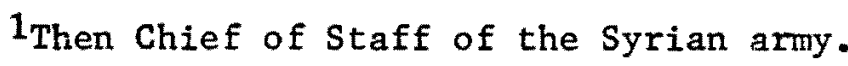

${ }^{2}$ Sarraj to Seale, in Seale, Struggle for Syria, p. 295.

${ }^{3}$ New York Times, August 22, 1957.

tquoted in Seale, Struggle for Syria, pp. 295.96. 
to do away with Syria's leftist regime despite Syria's claims of neutrality. On August 22, Deputy Under Secretary of State Loy Henderson, a leading expert on the Middle East, was sent on a mission to the area. His stops in Ankara and Beirut resurrected memories of the events which led to the fall of Dr. Mohammed Mossadegh in Iran in 1953. On his first stop at Ankara, Henderson conferred with Adnan Menderes, the Turkish Prime Minister, with King Faysal of Iraq, and with King Hussein of Jordan. In Beirut, he met President Chamoun. Back in Ankara, he conducted further discussions with Menderes, Crown Prine Abdul Ilah of Iraq and his army's Chief of Staff.

Henderson's trip made Syria and Egypt suspicious and drew bitter attacks from them and the Soviet Union. He was accusea by the three capitals of preparing to directly intervene in Syria through his expertise in staging coups d'etat. While Henderson was still in the area, a New York Times correspondent sent the following dispatch from Damascus:

There is no sign either in Egypt or in Syria that the Soviet bloc, with its technical, economic, military and cultural missions, is trying to Sovietize these two countries or to stir up a classic Marxist revolution. What the Soviet Union has found are two friendly Arab countries who are willing to help block Western efforts .... So far as it is known, there are no card-carrying communists among the officers of the Syrian armed forces. 1

In his first report to the State Department on September 5, Henderson described the situation as very serious. He reflected

${ }^{1}$ Quoted in Ibid., pp. 296-97. 
"deep concern lest Syria should become a victim of international comunism and, as such, become a base for further threatening the independence and integrity of the region. "1 On September 7, secretary Dulles issued a statement, after meeting with Mr. Henderson and President Eisenhower, in which he said, "There was particular concern over border incidents and intensive propaganda and subversive activities directed toward the overthrow of the duly constituted governments of Syria's Arab neighbors."2 Secretary Dulles added that President Eisenhower

affirmed his intention to carry out the national policy, expressed in the congressional Middle East resolution which had been adopted, and exercise as needed the authority thereby conferred on the President. In this connection, the President authorized the accelerated delivery to the countries of the area of economic and other defensive items which have been programmed for their use. 3

It should be remembered that Henderson's report was influenced by pro-Western states in the Middle East, which had no love for either Nasser or Syria or for their progressive national and neutralist policies. The report, therefore, was bound to be one-sided. But apparently Secretary Dulles heard what he wanted to hear. A program to strengthen the defenses of Syria's neighbors began as early as September 5. An airlift of arms to Jordan was announced; reinforcements were sent to Iraq and Lebanon; and Turkey concentrated her troops along the Syrian frontiers with American officers present. 4

${ }^{\mathbf{i}}$ Current Documents, p. 1037.

${ }^{2}$ U.S., Department of State, Bu1letin, XXXVII (September 23, 1957), 487 .

3 Ibid.

"No1te and Polk, "Toward a Policy for the Middle East," 646-47. 
A11 these measures were being taken while Syria was known to possess neither the capability to attack any of her neighbors, nor the desire to do so. Her policy was a purely defensive one. In fact, she was in a state of fear as to what might happen to her and worried about the possibility of not being able to defend herself in case she was attaciked. Trenches were being dug everywhere in Syria--an activity that President Quwatli took part in.

During a news conference in Moscow on September 10, Soviet Foreign Minister Andre Gromyko said to Soviet and foreign correspondents,

It goes without saying that the fabrications about some sort of complicity on the part of the Soviet Union in the Syrian events were needed to divert public attention from the aggressive actions of the United States in the Near and Middle East, particularly against Syria.1

Mr. Gromyko went on to say that, if the United States truly believes that Syria intends to attack her neighbors, the United States should take the matter to the United Nations. But because the accusations were not true, the U.S. government had not appealed to the United Nations. In fact, the accusations were so incredible that one is 1ikely to suspect that neither Dulles nor Eisenhower believed them. Turkey had an army of half a million men, superbly trained and equipped and proven in Korea; while Syria had a tiny army, il1equipped, poorly trained, and lacking in experience. That is why the Soviet Union, in a nota sent to Turkey on September 11, stated that

${ }^{1}$ Current Documents, 1957, p. 1039. 
no one can take seriously the biased assertions now being circulated that Syria is a threat to the security of this or that state in the Middle East. We think even those who resort to such assertions scarcely believe them themselves. 1

The same note contained a warning to the Prime Minister of Turkey. It said,

We shall not conceal the fact that we have met with great concern the report about Turkish troop concentrations on Syria's borders, as well as about the shipments of American alms to Turkey to effect an attack against Syria. . . We are confident, Mr. Prime Minister, you will agree that the Soviet Union cannot remain indifferent to these events. ${ }^{2}$

America's fear of communism made her overlook local Arab tensions. According to H.A.R. Philby, "the United States Government ignored the many warnings that must have reached it, not least from its own trusted officials in the area."3 The United States's anti-Syria attitude and actions got her involved in a long-standing Baghdad-Cairo rivalry for the control of Syria. Washington's policy, whether intentionally or not, was clearly in favor of Iraq's longcherished dream of winning control over Syria--the key to any degree of success in Arab leadership. The rulers of Iraq, Lebanon, Jordan, and Saudi Arabia knew that the communist danger in Syria was not serfous. But they also happened to agree then, mainly through an effort on their part to rally Arab support for the Eisenhower Doctrine and for their general opposition to Nasser, that a favorable

I Ibid., pp. 1042-43.

2Ibid., p. 1042.

3H.A.R. Philby, "Nasser and the West," Middle East Forum, XXXIV (Apri1, 1959), 40. 
change of regime in Syria was essential to the success of their pro-West policies.

It is in this context that some of them, at least, were willing to see Henderson's plan for military action against Syria come through. The trials following the Qasim revolution in Iraq revealed most of what needs to be known. The documents produced during those trials gave evidence of the unconventional methods contemplated by Henderson and those he met in Ankara. ${ }^{1}$ In his confession statement, Rafiq Arif, the former Chief of Staff of the Iraqi army, said that Loy Henderson told the Turkish and Arab officiais he met in Turkey,

If armed action is taken, reasons should be devised beforehand to make it possible to defend such action in the United Nations. - . The case should also be put in such a way as to reassure the other Arab states that this is not a war against Syria but action against a (treacherous?) state of affairs, and that communism is opposed to Islam as vel1 as to Christianity. 2

Professor George Kirk argues that with the Syrian situation as it was, the American government's fears were justified, and that Mr. Henderson and the "statesmen conferring with him in Turkey had discussed what action they might take against Syria in certain eventualities." 3 But that is all that is being claimed. It is sufficient to know that the United States government considered the situation in Syria serious enough to plan for military action against her and to carry it out when the circumstances demanded it.

I Ibid.

${ }^{2}$ Quoted in Seale, Struggle for Syria, p. 299.

${ }^{3}$ George Kirk, "The Syrian Crisis of 1957--Fact and Fiction," Internationa1 Affairs (London), XXXVI (January, 1960), 60. 
VI. THE SMELL OF DEFEAT

It did not take long for Syria's Arab neighbors to decide to reconsider their stand, however, as public censure began to expose their complicity, and as their fear of losing power paralyzed them. But as Turkey's forces remained poised at the Syrian frontiers, it became evident that she was the only Middle Eastern power that was still willing to play the Washington war game. Arab nationalists everywhere bitterly attacked the United States and Turkey. On September 13, the Soviet Union sent Turkey another warning. Premier Bulganin accused her of being an instrument in Washington's hands, ready and willing to fulfill the American intention of overthrowing Syria's government. A conflict with Syria would "not be 1imited to that area alone,"1 Bulganin warned.

At the United Nations, Secretary Dulles restated his fears, on September 19, "that Turkey now faces growing military dangers from the major buildup of Soviet arms in Syria on its southern border."2 He was followed on September 20 by Soviet Foreign Minister Andre Gromyko, who declared that the Soviet Union "cannot remain indifferent and observe from afar the attempts that are being made to turn the Near and Middle East into a permanent hotbed of armed conflict."3 To give force to Gronyko's words, two Soviet warships

${ }^{1}$ New York Times, September 14, 1957.

2U.S., Department of State, Bulletin, XXXVII (October 7, 1957), 558. $3_{\text {New }}$ York Times, September $21,1957$. 
arrived at the Syrian port of Latakiya the following day.

Like Dulles, Henderson, evidently, did not show an interest in seeking facts but a confirmatior of a conviction that Syria was going communist. Neither the U.S. government nor its emissary made any direct approach to the Syrian government in an effort to find out the reasons for the position taken by Syria, and as to how we11founded were the accusations leveled against her. This lack of openmindedness on the part of the U.S. government gave Russia the opportunity to come to Syria's defense and to gain greater support and respect among Arab progressive elements. Russia's notes to Western powers, calling for a joint declaration renouncing the use of force in the Middle East, ${ }^{1}$ gave public proof of her declared policy of peaceful co-eristence and the prevention of war.

Moreover, the position of Syria's government was strengthened rather than weakened. Pressure on Syria served neither the interests of pro-West Arab states nor the interests of the United States. Lebanon, Jordan, Iraq, and Saudi Arabia were finding it increasingly difficult, even embarrassing, to identify with U.S. policy. Their vulnerability to nationalist opposition forces was becoming dangerously alarming. The discovery of the plot against syria in August multiplied their troubles as they were discovered to be in the conspiratorial camp of Syria's enemies. Public censure and rational judgment forced them to moderate their views and to urge the United States to do so. Those states "mindful of Nasser's prestige and of

${ }^{1}$ Current Documents, 1957 , pp. 761-70. Russia's proposals were repeatediy rejected by the West. 
the unpopularity of American policy with many of their own subjects," says Malcolm Kerr, "got cold feet and disavowed any intention to join In pressure on Syria."1 On a visit to Syria, King Saud issued a statement on September 27 in Damascus before his return to his kingdom, saying,

On this occasion, I would like to declare without obscurity and ambiguity and with the sincerity for which $I$ an known by my Syrian brethren in particular and the Arabs in general that I denounce any aggression against Syria and against any other Arab country from wherever it comes. I shall resist with my Syrian brethren and the Arabs any aggression comitted against them and against their independence whatever its source may be. I do not think any Arab will sink so low as to harm any other Arab. 2

Speaking for Saudi Arabia at the United Nations Genera1 Assembly on October 2, Ahmad a1-Shukairy declared,

The affairs of Syria are for Syria. . . Who is in power, who is not in power, is the concern of Syria, and Syria alone. We are not here to deal with the change of governments. This domestic realm of internal affairs must remain immune, for it has been declared immune in the IUnited Nationsi Charter.

Shukairy affirmed that "Saudi Arabia sha11 stand by Syria in the defense of her sovereignty and independence. . Land shal1 resist $\bar{T}$ any attempt to interfere in the affairs of syria." 3

Sounding as criticism of U.S. policy, President Eisenhower replied to al-Shukairy's statement the following day during a press conference. "I do not know," he said,

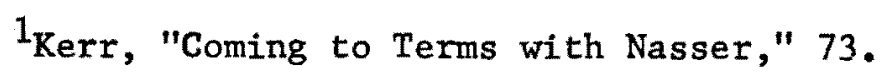

${ }^{2}$ Current Documents, 1957, p. 1044 .

${ }^{3}$ Ibid. 
what particular thing inspired the speech of yesterday. . . I do know this: Only within, almost hours, I received from the King of Saudi Arabia a message of warm friendship, expressing satisfaction in the things we have been able to accomplish through cooperation . . and the hope this friendship would continue to grow. 1

The President, however, conceded that the situation in Syria appeared to be solidifying somewhat, and

The original alarm of countries like Lebanon, Jordan, and Iraq, and to some extent Saudi Arabia, seems to have been quieted by what they have learned. . . . Just what grounds they have for that, I don't know, but I just can say this: We have tried our best to be friends with every nation in the area. 2

But had the United States government really tried to do so? If it had, she surely had not succeeded. Instead, Washington had to back down and gained only discredit as its Arab friends declared their support for Syria. The United States and Turkey were left alone to bear the brunt of the blame, and to appear as the only nations determined to take action against Syria.

Egypt's and Syria's victory was Russia's victory too. The launching of the first Sputnik of October 4 made Russia's victory a11 the more glamorous, and lent weight to her determination to defend Syria. To the Arabs, Russia had demonstrated her ability and determination to defend her friends.

King Saud's instant success and surge in popularity should have given a clue to the United States as to what would be a popular policy to follow in the Arab world. By edging away from Washington,

$1_{\text {Ibid., pp. } 1044-45 .}$

${ }^{2}$ Ibid. 
achievement, as far as modern Arab history is concerned, and a tremendous push forward for their aims of fulfilled nationalism and Arab unity.

Soon after, the only subscriber to the Eisenhower Doctrine, Lebanon, found herself in the throes of a crisis aggravated by President Chamoun's acceptance of the Doctrine. President Chamoun's espousal of the Eisenhower Doctrine, as well as his refusal to sever relations with Britain and France following the Suez crisis, had angered strong Arab nationalists in Lebanon. 1 The opposition accused Chamoun of having compromised their country's neutrality by leaning too far toward the West.

Lebanon's half-Muslim, half-Christian population lived in relative peace and stability under the "National Pact" of 1943. The Pact brought the two groups together when the Muslims agreed to give up their goal of union with the overwhelmingly Muslim Syria and the Christians agreed to sever their political ties with the West. This balance was disturbed when President Chamoun decided to endorse the Eisenhower Doctrine. 2 Under the existing political setup, "no government is at all possible in Lebanon," says Michael Adams,

1 Robert McClintock, "The American Landing in Lebanon: Summer of 1958," U.S. Naval Institute Proceedings, LXXXVIII (October, 1962), pp. 199-200; Michael Adams, "The Frustrated Civil War," The Reporter, XIX (August 7, 1958), 17. For a detailed analysis of the causes of the crisis, see Fahim Issa Qubain, Crisis in Lebanon (Washington, D.C.: Middle East Institute, 1961), pp. 30-47.

${ }^{2}$ Kamal Suleiman Salibi, The Modern History of Lebanon (New York: Praeger, 1965), Pp. 187-200. 
unless it enjoys at least the tolerance of what are in effect powerful feudal chieftains. President Camille Chamoun's mistake was first to embark on a foreign policy (pro-American and anti-Arab nationalist) bound to antagonize the Moslim section of the population, and then to provoke the enmity, not of one or two of these local leaders but of all of them, by so managing the general elections of June, 1957, as to exclude from the chamber of deputies almost every important opposition figure. 1

The tense situation in Lebanon found occasion to explode when on May 8 Nasib a1-Matni, editor of al-Telegraph newspaper, was assassinated in Beirut. By May 10, Tripoli was on general strike. Disorder and street clashes spread to Beirut and other cities. The declared reason for the civil disturbances was the supposed intention of President Chamoun to run for a second term. ${ }^{2}$

On May 17, the Department of State issued a statement outlining the conditions under which the United States armed forces might be sent to Lebanon. The statement said that the government of Lebanon had not as yet asked for American military assistance, and that American property and lives were not in danger yet. ${ }^{3}$ In reply to questions during a press conference on May 20, Secretary of State Dulles said thet there were several provisions under the Eisenhower Doctrine for the use of force in Lebanon. There was the provision to help preserve the independence of nations, especially when their

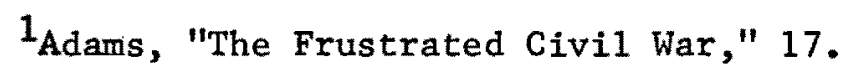

${ }^{2}$ Salibi, Modern History of Lebanon, pp. 200-201; Qubain, Crisis

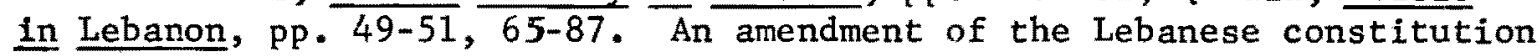
was required because continuing in office for a second term would be contrary to its provisions.

${ }^{3}$ Current Documents, 1958 (Washington, D.C.: Government Printing Office, 1962), pp. 937-38. 
independence is considered vital to world peace and American national interests. There was also the provision to use force in support of nations uncier attack from communist-controlled countries. And there is the basic right for the United States to protect American lives and property. 1

VIII. THE CASE BEFORE THE UNITED NATIONS

When Chamoun's government discovered that the opposition leaders were drawing on sources in Syria and Egypt for support, it lodged a complaint on May 22 before the United Nations Security Council charging the United Arab Republic with interference in Lebanon's internal affairs. ${ }^{2}$ Lebanon's complaint was not considered by the Security Council, however, until June 6, to allow the Arab League time to consider another Lebanese complaint to it. The failure of the Arab Jeague to solve the problem left it for the Security Council to settle. During its first meeting, the United States representative said that the evidence of outside interference supplied by Lebanon was "very impressive" and urged "all concerned . . . to maintain respect for the independence and the integrity of Lebanon and to prevent any actions and developments inconsistent with this objective." $" 3$

On June 10, the U.S. representative at the United Nations,

${ }^{1}$ Ibid., pp. $938-39$.

2Ibid., P. 940.

3Ibid., p. 941 . 
Henry Cabot Lodge, reaffirmed his government's conviction that the evidence of interference by the United Arab Republic was conclusive and declared, "There should be no doubt of the firm determination of the United States to continue to support the integrity and independence of that country." 1 In answer to Soviet criticism of U.S. policy through the Soviet representative at the United Nations, Lodge added,

The Soviet strictures against the United States are so standardized that it would be a waste of time to demonstrate their absurdity. And this is one night, Mr. President, in our history, when we must not waste time. Yet instead of joining forces with us to do something quick and helpful the Soviet representative seems to be looking for reasons not to do something. 2

After five days of debate, the United Nations Security Council adopted a resolution of June 11 to dispatch a U.N. observation group to Lebanon. ${ }^{3}$ On July 1, Secretary Dulles outlined the prerequisites for direct American military assistance to Lebanon. "We do believe," he said,

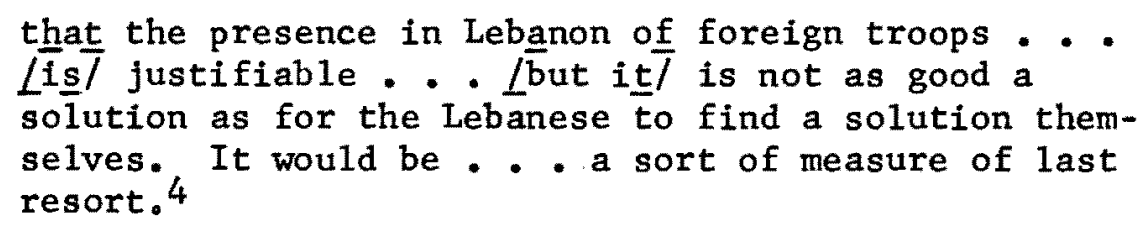

In its report of July 3 , the U.N. observation group reported

$1_{\text {Ibid., p. } 943 .}$

${ }^{2}$ Ibid., p. 944 .

${ }^{3}$ Text of resolution, in U.S., Department of State, Bulletin, XXXIX (Ju1y 14, 1958), 90.

${ }^{4}$ Current Documents, 1958, p. 952. 
difficulty in the observation of the Lebanese-Syrian borders due to the fact that most of the border areas were not under the control of the Lebanese government, that the rebels had not "formally anu implicitly recognized" the group's right to observe, and that the nature of the terrain made the task more difficult. In cities, observation was not possible except by previous arrangement. It was, therefore, not possible to determine, the group reported, whether arms and men "had infiltrated from outside; there is little doubt, however, that the vast majority was in any case composed of Lebanese."1 Besides, the American Ambassador in Beirut, Robert Mcclintock, had to tell President Chamoun that "evidence of U.A.R. interference was far from conclusive." 2

\section{THE LANDING OF U.S. MARINES}

But President Chamoun was counting on American help, when it was deemed necessary, under the terms of the Eisenhower Doctrine. According to Miles Copeland, there was sufficient reason to believe that a compromise settlement would have been worked out had it not been for President Chamoun's refusal to cooperate and for the. July 14 coup in Iraq. In fact President Eisenhower confirmed this view by saying, "In early Ju1y it appeared that the Lebanon crisis would pass without Western military assistance." 3 The main reason

${ }^{1}$ Ibid., pp. $952-58$.

${ }^{2}$ Copeland, The Game of Nations (New York), pp. 238-39.

3Eisenhower, Waging Feace, 1956-1961, p. 269. 
for Chamoun's refusal, says Copeland, was his belief that American help would be forthcoming on demand. ${ }^{1}$ Chamoun is reported to have told Alnbassador McClintock that the United States "must either promise to support him or else watch his and every other pro-Western regime in the Middle East, including Iraq and Jordan, fall like ninepins to the Egyptian."2 The Ambassador, in turn, cabled Washington urging measures to enhance involved American prestige in Lebanon and to "be prepared either to support the current regime in resisting subversion or to cut its losses and learn to live with a great Arab nation presided over by Nasser." 3

Charles Thayer contends that Secretary Dulles's June statement that "if the United Nations was unable to protect the legitimate government of the Lebanon, the United States would undertake to do so -. - by force if necessary," was taken to mean that Chamoun was issued a "blank check" ly Washington which he could "cash" anytime it became necessary. "Just who was to define 'necessary'," says Charles Thayer, "was not clear but President Chamoun at least assumed that this was his prerogative." In fact, Chamoun, more than once, tried to get the United States to intervene on his behalf before she finally did immediately following the July 14 Revolution in Iraq."4

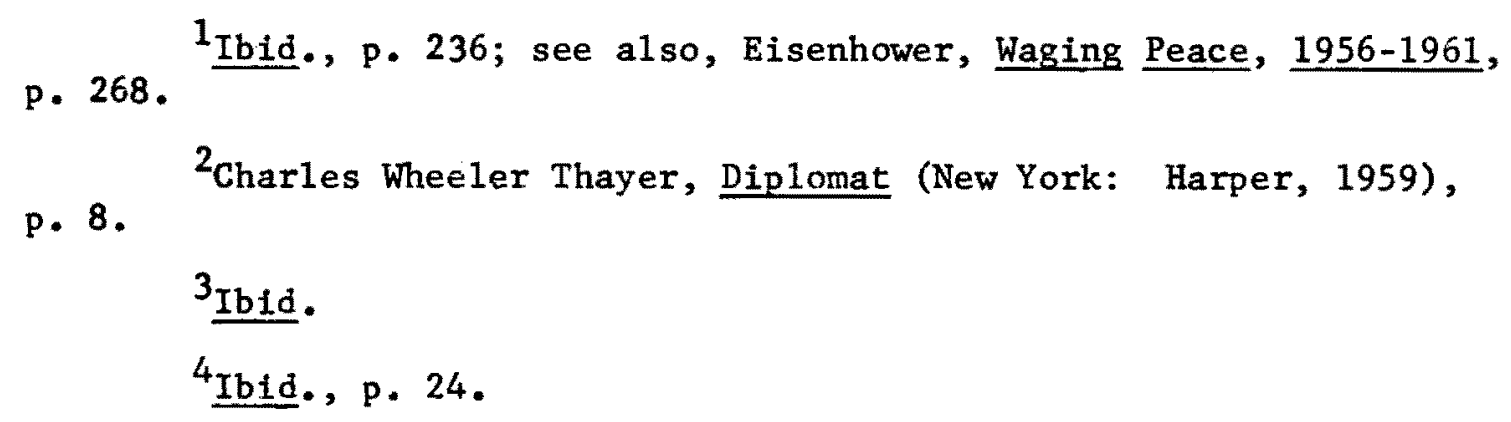


The surprise coup in Iraq, while the Lebanese civil war was still smoldering, put the Eisenhower administration on the spot and faced it with what appeared to be an inevitable necessity to act to salvage some of the crumbling fabric of the Western position in the Middle East. President Chamoun immediately requested American troops. Ambassador McClintock assured him that they "would arrive within forty-eight hours--not realizing," says Miles Copeland,

that the fleet was only a day away. The fleet arrived in less than twenty-four hours, to unload wave after wave of grim-faced Marines, rifles poised for action, to be greeted by startled bathers sunning themselves on Beirut's beautiful beaches and hordes of little boys selling chewing gum. 1

Miles Copeland asserts that the CIA had information of U.A.R.planned and backed coups against Nuri al-Said, King Hussein and Chamoun. Ambassador McClintock affirms that "Washington had very reliable information that . . a coup d'etat had been scheduled against King Hussein of Jordan for $17 \mathrm{July."2} \mathrm{McClintock}$ concludes, therefore, that the American landing in Lebanon and the British airlift to Jordan

were undoubtedly decisive in preventing the wiping out of the Lebanese and Jordanian governments by force in a manner similar to that of the Iraqi government in Baghdad. In consequence, it can be fairly said that this limited use of force was successful in achieving the political objective, which was to maintain peace in the Middle East and to show the world generally that the United States and Great Britain, with the support

${ }^{1}$ Copeland, The Game of Nations (New York), p. 239. 2McClintock, "American Landing in Lebanon," 69. 
of their allies, were ready to go to great effort and risk to assist small, free, friendly nations to majntain their integrity and independence. 1

Robert Murphy, President Eisenhower's emissary to the Middle East following the Qasim coup in Iraq, says that the President wanted to show that the United States was not afraid of the Soviet Union and that she was capable of more than just words. The "military action," says Murphy, "undertaken at the expressed desire of the constitutional head of the Republic of Lebanon, was based on the traditional American policy of protecting our citizens and defending our national interests." Murphy adds that President Eisenhower expressed the belief

that if the United States did nothing now, there would be heavy and irreparable losses in Lebanon and in the area generally. He wanted to demonstrate in a timely and practical way that the United States was capable of supporting its friends. 2

According to Ambassador McClintock, the landing of U.S. Marines in Lebanon achieved four things: (1) Lebanon's integrity and independence were maintained; (2) the United States, by intervening, proved to the whole world that she was ready to defend her friends be they big or smal1; (3) the presence of the Marines helped cut short the process of reconstruction and prevented the crisis from continuing; (4) "American intervention in Lebanon destroyed the myth In Arab eyes of Soviet invinsibility." 3

$1_{\text {Ibid. }}, 74$.

2Murphy, Diplomat Among Warriors, p. 389.

3McC1intock, "American Landing in Lebanon," 77. 


\section{FACT AND FICTION}

The decision to land the Marines in Lebanon and to back a British troop airlift to Jordan won solid popular approval in the United States. But this general support lasted only for the duration of the crisis. The shortcomings and failures of U.S. policy in the Middle East were becoming obvious, and the Democrats were determined to press for a review of it once the crisis was over. Some Pentagon officials complained that the repeated failures were a result of America's unwillingness to allow Britain, France, and Israel to bring an end to the Nasser menace in 1956. Senator William Fulbright, displaying more thoughtfulness, reasoned, "We have never made the fundamental policy decision as to whether Arab nationalism-epitomized in Nasser--was a force with which we should try to work, or a force we should oppose."1

Mr. Dulles seems to have had the conviction that the military intervention in Lebanon was necessary to safeguard the integrity and independence of small nations in Asia and Africa. Those nations, it was thought, were reassured by the swift American action in the Middle East--a public and practical demonstration of U.S. readiness to support her allies everywhere. It, however, soon became evident, even to Secretary Dulles, that the landing of the Marines in Lebanon was not about to solve America's problems in the Middle East, or in other parts of the world. The immediate and pressing task of the

${ }^{1}$ Quoted in "The Eisenhower Doctrine: Beginnings of a Middle East Policy," 358-59. 
Eisenhower administration became the withdrawal of those Marines without too much embarrassment and loss of face.

The aggressions that Nasser and Moscow were blamed for vere found to be not so easy to identify and separate. Blaming Nasser and Moscow for America's problems in the Middle East is "an oversimplification," Round Table commented, "Senator Fulbright reasons that what is happening is not the loss of the area to communism but its gradual hand-over to Arab nationalism." 1

Moreover, what was thought to be a Nasser-inspired coup in Iraq, turned out to be a surprise even to him. On an exploratory trip to Iraq, Robert Murphy met Abd al-Karim Qasim. Murphy reported that Qasim's justification of the coup was "that only by such unconventional means was it possible for the impoverished people of Iraq to get rid of their corrupt royal regime. "Kassim," Murphy added, "stressed the purely domestic character of the revolution, which he said had been organized for national rather than ideological reasons." To Murphy's question about Russian influence in Iraq, Qasim assured him "that he had not risked revolution for the purpose of handing Iraq to the Soviet Union.. . $\overline{\text { or }} \bar{T}$ in order to make Iraq subservient to Egypt." 2

In this connection, it is significant to note that Russia was not less surprised at what took place in Iraq than Nasser. Muhammad $\mathrm{H}$. Haykal reports that Nasser first heard of the Qasim coup over BBC

$1_{\text {Ibid., P. } 359 .}$

2Murphy, Diplomat Among Warriors, pp. 413-14. 
radio while at Brioni with Marshal Tito. Upon hearing the news of the coup and of the landing of the Marines in Lebanon, Nasser made up his mind to go to Moscow instead of following his earlier plan of returning to Cairo. He arrived in Moscow on July 17 with the intention of finding out what the Soviets were prepared to do in the Middle East in the light of those developments. Khrushchev first gave Nasser the impression that he was finding it difficult to formulate a policy because events were occurring in quick succession. 1

But Khrushchev soon was able to tell Nasser that the Soviet Union was not ready to face the United States because she was not prepared for a third world war. When Nasser said that he was going to fight if Syria were attacked, Khrushchev advised that he shouid bend with the storm. "Dulles thinks himself a minister of the gospe1," said Khrushchev, "but though I am an athiest, I am nearer to God than he is because he has no heart." Nasser pleaded with him to issue a warning like the one Russia issued during the Suez crisis, 80 possible Western action against Iraq or Syria could be prevented. Khrushchev refused on the grounds that he did not want to do anything that might lead to war. All he was ready to do was to conduct military maneuvers along the Bulgarian-Turkish borders. "This is only a maneuver;" Khrushchev reminded his guest, "I beg you Mr. President to remember that it is nothing more than a maneuver." 2 Nasser

\section{1,}

${ }^{2}$ Ibid.; this agrees with Dulles's assessment of the Soviet position immediately preceding the landing in Lebanon; see Eisenhower, Waging Peace, 1956-1961, p. 271 . 
should have remembered that, during the Suez crisis, both Russia and the United States were united in their opposition to the use of force in Egypt.

About Qasim, Khrushchev says that he could see he "represented the progressive forces of Iraq. We already had some information on Kassem. He had had sporadic contacts with communists and called himself a communist." He adds,

We could tell from Nasser's reaction... that the news came as a complete surprise to him. . . Shortly before the coup in Iraq, Egypt and Syria had formed the United Arab Republic, and Nasser nourished the hope that the new Iraqi government would fall into line with the policies of Egypt. This was a completely understandable desire, but as it turned out, neither Nasser's hopes nor our information about Kassem were borne out. Kassem turned out to be highly unstable politically. 1

Arab reaction to the landing of the Marines in Lebanon was generally hostile. Arab nationalists attacked the action and denounced it as armed aggression. The British landing in Jordan met with stronger resentment because British planes flew over Israeli territory to get to Jordan. ${ }^{2}$ In Lebanon, several of Chamoun's supporters turned against him when he called the Marines. 3 The Wa11 Street journal reported that the Speaker of the Lebanese House of Parliament, Adil Osayran, who until the landing "was a supporter of President Chamoun and his harassed government, calls the U.S. landing 'an act of aggression.' His sentiment is echoed by other

${ }^{1}$ Khrushchev, Khrushchev Remembers, p. 438.

2a1-Ahram (Cairo), October 15, 1971.

3 New York Times, July 18, 1958. 
politicians who had been counted in the pro-Western camp."1

The Lebanese crisis and the Iraqi Revolution of 1958 demonstr.ted that an alliance of two Arab nations with the West "in defiance of the others cannot be regarded as a working defense arrangement against the soviet bloc."2 As it was expected, Chamoun's government was replaced by one dominated by the opposition. General Shihab, the Chief of Staff, who refused to use the Lebanese army against the opposition, became President, and Rashid Karami, the opposition leader in Tripoli, became Prime Minister. ${ }^{3}$

\section{NEW REALITIES}

The 1958 chain of events, which followed a series of failures suffered by the West in the Middle East, forced upon the United States the realization that her approach to Middle Eastern problems was not working. Foremost among her objectives in the Middle East was the preservation of the status quo for the protection and promotion of American and Western interests. This objective was sought first through an unsuccessful bid to bind the area's states in a regional defense system. When this objective met with Egypt's

$1_{\text {Wa11 }}$ Street Jouma1, July 22, 1958; see also, Eisenhower, Waging Peace, 1956-1961, pp. 280-81.

${ }^{2}$ Majid Khadduri, "American Poreign Policy in the Middle East," S.A.I.S. Review, V (Spring, 1966), 22.

3Qubain, Crisis in Lebanon, PP. 154-56; it is significant to note that these were the two individuals Nasser suggested, and for the same positions, when in June he was approached about a compromise solution in Lebanon; see Copeland, The Game cf Nations (New York), p. 237; see aiso, Eisenhower, Waging Peace, $\overline{1956-1961}$, p. 268. 
and Syria's strong resistance, the United States and the West sought an alliance that would draw to it those states which wished to join In the hope that Egypt could be isolated and her bid for Arab leadership checked. But this alliance, known until 1958 as the Baghdad Pact, drew only one Arab state to its ranks.

The final attempt, differing mainly in the fact that it was a purely American initlative, could eventually boast only one Arab subscriber, Lebanon. But the very fact that those two states joined the respective Western alliances constituted a danger both to their regimes and to American and Western interests. "The trouble," says Sidney Lens, "as Iraq proves so eloquently, is that military bases are no more formidable than the stability of the country in which they are built. If a 'friendly' regime topples, our bases topple with it." 1

The Important American discovery in 1958 was that the longheld concept of preserving the status quo was a wrong concept and that, if the United States were to guard her interests and position in the area, she had to undo most of what she had done in the preceding decade. Before 1958 came to a close, the Baghdad Pact had to be renamed since Baghdad had defected ${ }^{2}$ and Lebanon's new regime hastened to withdraw that country's support of the Eisenhower Doctrine because Lebanon's troubles were mainly blamed on the Chamoun governnent's

${ }^{1}$ Sidney Lens, "The Dulles Dilemma in the Middle East," The Progressive, XXII (September, 1958), 7.

2It came to be known from then on as the Central Treaty Organization. 
endorsement of it.

The United States finally realized that her past preoccupations wi ch Middle East defense made her cverlook the importance of economic and technical aid programs, and to see neutrals as enemies, who deserved neither aid nor sympathy. Though the United States continued to see the Soviet Union as presenting a serious threat to the Middle East, "its ability to use Arab states for its own purposes was downgraded."1 American statesmen were fina1ly convinced that they could not go on fighting "both communism and Arab nationalism, and still save the Middle East."2

The Eisenhower Doctrine proved to be a costly experiment. It showed the wide gap that separated Arab views from those of America on the seriousness of the communist threat. Its net effect was disunity, new tensions, new division, and new problems. 3 "This whole episode," says Edward Buehrig, "so 1amentab1y 1acking in any of the arts of diplomacy, has had dubious results for American policy."4

Having seen his plans for the Middle East go down in defeat and, having watched the prestige of the United States sink to its a11-time low in that area, Secretary of State John Foster Dulles died.

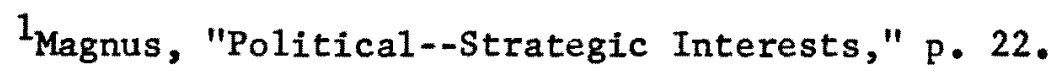

2Campbe11, "America and the Midd1e East," 149.

$3^{3}$ Thornburg, People and Policy in the Midd1e East, p. 31.

4Edward Buehrig, "The Arab World and the United States: A Critical Survey of American Policy in the Middle East," Middle East Forum, XXXIII (July, 1958), 31. 
American dipiomats in the Arab countries, "bitter about the Eisenhower Doctrine (which they had almost unanimously opposed), began advocating 'facing the fact of Nasser' and realizing that the 'Arab world of 1959 is not that of Lawrence of Arabia." 1 Christian Herter took over as Secretary of State and the American government began to grope toward the reestablishment of friendly ties with the Arab countries.

It became sufficiently clear that the United States was not able to enforce her wishes in the Middle East. A trend, therefore, was begun during the last two years of the Eisenhower period to emphasize the economic aspects of her aid program and to develop a gradual rapprochement with the radical or progressive Arab countries, notably the Inited Arab Republic. This meant improved relations with Nasser, readiness to respect the interests of his new U.A.R. and the forces which supported it, and offering constructive help for her development. This was an implicit admission of past U.S. failure and an acknowledgement of the successes of Nasser and Arab nationalism. Under those circumstances, all the United States could hope to accomplish was, to a certain extent, channel the tide of Arab nationalism or deflect it a bit from its course. It became necessary for the United States to realize that the Arabs were to be treated as equals and that any attempt to go against the nationalist tide would not be accomplished through the deployment of armed force. It was hoped that such a policy would dissuade Nasser from capitalizing on Western disasters and failures and would help restore a measure of confidence

${ }^{1}$ Copeland, The Game of Nations (London), p. 220. 
between the United States and the Arabs. In the words of Malcolm

Kerr,

For the United States it bucame necessary to review her cold war requirements and settle on minimally acceptable, rather than ideally desirable, goals. Instead of organizing Arabs for defense against a Soviet invasion that none feared, America had to leave the Arabs' international and domestic politics to their own good or bad judgment, and hope that Arab governments would become sufficiently absorbed in domestic affairs to abstain from adventures that might precipitate a renewed American Soviet involvement. 1

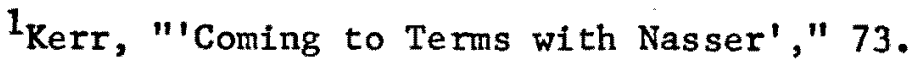




\section{CONCLUSION}

The post-War involvement of the United States in the Middle Bast came suddenly and without much preparation. The need to replace Britain and France in the Middie East required a reorientation of America's post-War plans and policies. As she was thrust upon the Middle Eastern stage, the United States faced four major problems. The first and most disturbing was a potential Soviet threat to take control of the Middle East. The second was the Arab-Israeli conflict over Palestine. The third was a contest between her own interests and the interests of Britain and France. The fourth was inter-Arat rivalry, which threatened to make it difficult for the United States to deal with them. In the words of Robert Strausz-Hupé,

The Middle East has confronted the United States with a series of painful dilemmas, essentially moral ones: how to reconcile diverse "rights" to national self-determination with one another; how to reconcile diverse "rights" of national self-determination with the claims of America's allies; how to square the United States' obligations to the United Nations with the United States' diverse stated positions vis-a-vis allies, neutrals, and enemies; and finally, how to compromise ideals of democracy by condoning, here and now, the usually undemocratic practices of weak rulers. 1

The United States wanted and needed Arab oil and friendship, but outraged and estranged them by her open-handed support of Zionisni. When the United States was given the chanse to participate in an AngloAmerican Compittee of Inquiry on Palestine, President Truman blew

\footnotetext{
p. 6 .

1Strausz-Hupé, "The United States and the Middle East,"
} 
up its carefully prepared "reconmendations by publically endorsing its pro-Zionist sections."2 The Arab refugee problem, which was calsed by the creation of the State of Israel, added to the bitterness toward America and continues to serve as a reminder of what took place in Palestine. In Arab eyes, the Palestine policy of the United States constituted a betrayal of their interests and rights and a negation of American moral principles. This is an issue that Arabs fully agree on be they pro or anti-West.

In Iran and Turkey, American policy was successful because those two countries were willing to accept the kind of help the United States was ready to give. The policy of containment went through its first tests in Iran and Greece. It was successful in the sense that what appeared to be a Soviet attempt to, directly or indirectly, take control of those two states was thwarted by a firm American stand behind the traditional rulers of Greece and Iran. The status guo in both countries was preserved.

When the United States sought Arab participation and support In an effort to erect a collective anti-communist defense system In the Middle East, the Arabs refused to cooperate because they felt it not in their best interests to do so. They, like the United States in her developmental era, preferred to remain neutral. Besides preserving their independence and national sovereignty, they, as neutrals, could draw on both suurces for aid. As a stop-gap arrangement,

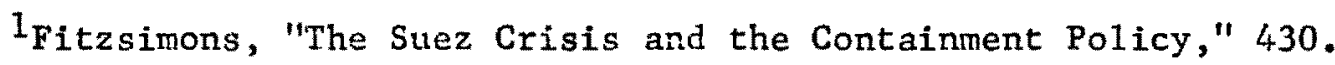


therefore, meant to preserve the status quo and through it the safety and security of the State of Israel, the United States joined Britain and France in issuing the Triparcite Declaration of 1951 guaranteeing Arab-Israeli frontiers and refusing to supply arms to belligerent states. This policy worked as long as the Western powers continued to be the major suppliers of arms to Middle Eastern states. When the Soviets began supplying Syria and Egypt with arms in 1955, however, the Western monopoly on the sale of arms in the Middle East was broken and the efficacy of the 1951 Tripartite Declaration came to an abrupt end. According to M.A. Fitzsimons, "it may be argued that for the period 1946-1955, when the Soviet Union was neither conspicuously active nor influential in the Middle East, United States policy contributed little to the solution or easing of the area's all but intractable problems."1 In fact, her choice to preserve the status quo placed her in opposition to revolutionary change in the Middle East and opened the way for the Soviets to pose a serious challenge to America's position in the area.

The newly independent nations of the Middle East badly needed economic development and industrialization to help transform their backward agrarian societies into modern urban communities, to create national power and unity, to help acquire military strength and international recognition. A better life for the exploited, bitter and resentful masses was earnestly sought along with the attainment of a national self-determined existence, free from foreign interference.

Ibid., 419. 
In the Arab world, Arab nationalism has been the decisive social and political force since the late $1940^{\prime} \mathrm{s}$. An understanding of its goals, desires and fears was essential for the success of relacionships between any state and the Arab world. In an effort to reassert national pride and dignity, the leaders of this movement sought to foster unity, independence, neutrality, social and economic reform, liberty and justice. They blamed the ills of their society on the West, especially Britain and France. Street demonstrations and antiWest propaganda were violent expressions of an over-suppressed desire and too-long thwarted aspiration for independence and unity. Military strength was sought to safeguard their independence and their reform programs.

In the struggle between the United States and the Soviet Union for the control of the Middle East, the crucial issue was winning the allegiance, friendship and good will of the people of the Middle East by dealing with them on the basis of a mutually advantageous relationship. The United States, maintaining a superiority over Russia in economic and military strength, had an excellent fighting change. Until 1953, the Soviet Uniun was unattractive under Stalin and direct control was preferred before Russian aid was extended. Moreover, the post-War Stalin era was a hard one for the Soviets. They were busy consolidating their position in eastern Europe and dealing with enormous internal problems, not the least were post-War reconstruction and rehabilitation. Had the nations of the Middle East been helped by the United States toward economic development, they would have assisted in keeping the Soviet Union out of the Middle East. The United 
States, however, had to be willing to allow the needed revolutionary transformation and the unseating of the feudal ruling classes to effect a drastic social and political change in preparation for economic development.

Instead, the cooperation of the United States with the existing regimes guaranteed support and backing for the privileged and reactionary ruling classes, whose aim was to hold to their privileged positions of power and keep the rest of the population in their undesLrable backwardness and landlessness. When the United States eventually established close cooperation with the former colonial powers, the worst fears of the people of the Middle East were confirmed. Her alliance with reactionary dictators and with colonialism made the United States suspect in the eyes of the Area's people. America's anti-revolutionary policy was the result of her inability to understand the nature and deeper social struggles of the people of the Middle East. Americans have not had to go through the problems plaguing the nations of the Middle East. They, therefore, could not understand them. National socialism was popularly identified in the United States with revolutionary communism. American industry and capital have a powerful influence in government and stand to lose their investments and cheap raw materials under revolutionary regimes. Chester Bowles has observed that many young Arab students come to the United States for study. "In our universities," he said,

they learn about Jefferson and Lincoln and other great men who have helped create our democracy. They go home fired with the hope that they can do something for their own people, only to 

find a deadly entrenched feudalism, often supported political-
ly and economically by American money, diplomacy, and tanks.

In an effort to secure the Middle East against Soviet intrusions, the containment policy took on the form of a military campaign designed to meet what was thought to be a military threat by the Soviet Union. Soviet communism was seen as a threat to the American way of life. The stiff and unpragmatic Soviet policy under Stalin was met with military pacts, alliances and involvements on the part of the United States and her allies. American foreign policy supported any anticommunist regime. Though reactionary and rejected by its own people, the fact that it was pro-American and anti-communist gratified such a regime in American eyes as "democratic." National movements to overthrow those regimes were opposed and suppressed.

To Secretary Dulles, the communist question was a moral one. The struggle between "democracy" and communism was a struggle between good and evil. But that is not how Middle Eastern nationalists viewed the problem. Despite a significant change in Soviet foreign policy following Stalin's death in 1953, the Eisenhower administration still sought to achieve the same ends in the Middle East through essentially the same means employed by Truman and Acheson, and in spite of an impressive record of failure. Washington continued to assune that recipients of American aid should automatically become friends and allies against Soviet communism. Though vitally important In terms of American security, economic aid was often viewed as charity

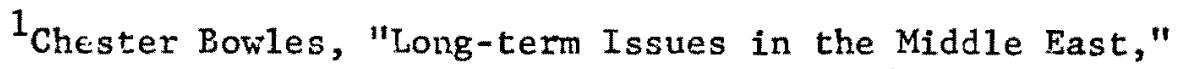
Academy of Political Science Proceedings, XXVI (May, 1957), 107. 
or en indication of American generosity. No far-sighted planning was worked out to take into consideration long-range American security considerations. It is not surprising, therefore, that, by 1958 , American influence came close to being nonexistent in the Arab world. The new Soviet approach attempted to identify Soviet aims and objectives with the goals and aspirations of the Arab nationalists. The Soviets were ready to cooperate with any force that opposed the West. Their post-1953 foreign policy approach succeeded because, while the United States was saying, in Senator Hubert Humphrey's words, "'those who are not with us are against us,' . . the Soviet spokesmen were saying, 'those who are not against us are with us.'" Senator Humphrey adds that in a conference in Cairo, the Soviet delegate, in presenting his country's foreign policy, said,

We do not ask you to participate in any blocks, reshuffle your governments or change your domestic or foreign policy. We are ready to help you as brother helps brother. . . . Tell us what you need and we will help you and send, according to our economic capabilities. 1

This shift in Soviet foreign policy was not fully understood by Washington or, at least, was not successfully combatted. The United States did not believe the Soviets could deliver on their promises. She continued to insist on concrete and immediate returns and guarantecs for her aid. Those returns and guarantees included demands that no national leader could afford to satisfy without considerable loss in power and prestige in the eyes of his own people. Moreover, such demands were self-defeating because they tended to undermine the

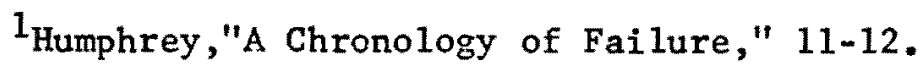


position of the same leaders Washington was trying to work with.

The Soviets, on the other hand, were content to see nationalist leaders achieve their objectives and secure their non-alignment with the West. Any American attempt to oppose them could only be in Soviet favor. To the Arabs, this was a golden "opportunity to better their own position and gain a freedom to maneuver they never enjoyed before."1 According to Walter LaFeber,

The Secretary of State knew that, as he phrased it, "to oppose nationalism is counter-productive," but as late as June 1956, his views of communism and an apparent confusion over the meaning of nationalism enabled Dulles to say that neutrality had "increasingly become an obsolete conception and, except under exceptional circumstances, it is an immoral and short-sighted conception." 2

Sidney Lens observed that, as a statesman, Dulles worked hard to draw allies and supporters for American policy. He failed, however, because he had a blind spot that prevented "him from seeing and understanding the nature of the revolution sweeping the underdeveloped areas of the world." Lens contends that a wise Dulles would have recognized that neutralists were the greatest bulwark against communism and that, through them, the whole developing world could have been sealed off against communist intrusions. ${ }^{3}$ Washington's insistence that neutralism aided the Soviets and was, therefore, anti-American greatly contributed to the deterioration of America's position in the Middle East.

${ }^{1}$ Campbe11, The Middle East in the Muted Cold War, p. 9.

2 Walter LaFeber, America, Russia and the Cold War, 1956-1966 (New York: Wiley, 1967), p. 173.

3Lens, "The Dulles Dilenma in the Middle East," 7. 
A revoluticnary regime has no choice but to maneuver between the great powers to free its economy, to industrialize, and to maintain hei independence. The fact that neutralists were considered antiAmerican made it almost impossible for the United States to differentiate between nationalists and communists. When she chose to oppose them, the nationalists could not avoid seeing her as an enemy.

Soviet policy was flexible enough and pragmatic enough to ignore the fact that communist parties were suppressed and their members persecuted by local regimes and that nationalism and communism did not agree on ideology. In contrast, American policy did not even conform to the declared "new outlook" of the Eisenhower administration in foreign policy, which promised to give special attention to the interests, desires, and hopes of the newly independent nations of the world. As an extension of this approach, Secretary Dulles declared in the spring of 1953, "The United States should seek to allay the deep resentment against it that has resulted from the creation of the State of Israe1."1 The United States made it known that her intention was to follow a policy of impartiality as between the Arab states and Israe1. Unfortunately, however, the United States did not succeed in being consistently impartial. Washington's difficulty in following a strictly impartial policy in the Arab-Israeli zone was complicated by heavy minority pressures in the United States. By 1958, "a ha1fbillion dollars of official United States assistance was given to

$1_{\text {Dulles, }}$ "Report on the Near East," 835. 
Israel, amounting to two or three times the sum contributed to a11 the Arab countries combined, and even private American gifts have been gimen a quasi-official nature by being mace tax exempt."I Harold $B$. Minor was prompted to comment, "There has been... such a wide gulf between policy enunciation and application that we need to examine critically the meaning of this word impartiality."2

The American stand on Suez against aggression stands out in bold relief as the most positive American act in support of intemational freedom and justice. But the real reasons for this stand were clashing Western interests, the American belief that an attack against Egypt could not achieve the desired objectives of the United States and her allies, and the fear that such an attack could provoke a general war. Nevertheless, it was an act that was greatly appreciated by the Arabs and gave the smaller nations of the world a new hope that justice and liberty can be preserved. The Suez crisis, however, unleashed powerful emotional and social forces determined to reshape life in the Middle East. This dynamic movement was seen by Washington and its allies as a wave of conspiracy and intrigue to be blamed on Nasser of Egypt and his supporters in the Arab world.

The very fact that this was the view from Washington strained relations between Arab nationalists and the United States. No one can deny that there was intrigue, conspiracy, and subversion, but

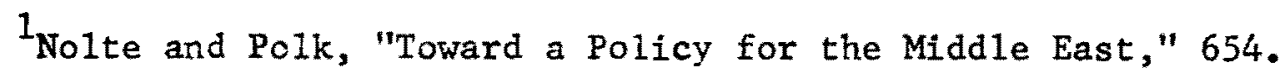
2Harcld B. Minor, "Commentary Lon Elie Salem's Problems of Arab Political Behavior 7 ," in Philip Warren Thayer, ed., Tensions in the Midule East (Baltimore: Johns Hopkins Press, 1958), p. 89. 
Nasser cannot be blamed for all that took place--Iraq and Saudi Arabia were not idle. "But the real question was," says Harry Hopkins, "not whether there was Egyptian 'subversion,' but why that 'subversion' was so uniquely successful." The answer that Hopkins provides is that Nasser's message expressed what his "listeners had long been waiting to hear; it went over the heads of Rulers, sheikhs, pashas, muftis, mudirs, omdas, and all their manifold Excellencies, and directly addressed the man in the bazaar and the fellah in the village."1

Washington's policy reaction to this post-Suez fever was a determination to isolate Egypt and Syria or to bring about a change of government, at least in Syria. As the main centers of Arab nationa1ist activity, those two countries were not expected to endorse the Eisenhower Doctrine--an anti-communist alliance not really meant to include them. Instead of isolating Syria and Egypt, Washington's policy brought them closer together and to the Soviet Union. The Eisenhower Doctrine was endorsed only by Lebanon and, in early 1958, Syria and Egypt became one United Arab Republic.

Before 1958 came to a close, Iraq, the only Arab member of the Baghdad Pact, and Lebanon, the only adherent to the Eisenhower Doctrine, defected. Arab nationalists had made great gains and the Soviet Union was we11 on her way to achieving her objectives in the

$1_{\text {Hopkins, Egypt, the Crucible, p. } 187 .}$ 
Middle East. The Soviet deliveries of arms to Syria and Egypt, which began in 1955, were followed by Soviet economic and technical ald to both countries and in 1958, the Soviets finally advanced an offer to help build the High Aswan Dam for Nasser. In 1959, Egypt began to get American aid too, which signified a tacit acceptance of Nasser's terms by Washington. This was an acceptance, though reluctant, of the facts of Arab nationalism and neutralism as expressed by Nasser. Washington was forced to recognize that the forces of nationalism were capable of undercutting her influence because their desires and hopes were the genuine hopes and desires of the people of the Middle East, which were neither manufactured by Nasser nor imported from Moscow. The Soviets, despite Washington's resolve to contain them, had, by 1958, entered the Middle East in full force. The Truman Doctrine, the Baghdad Pact, and the Eisenhower Doctrine have failed to keep them out. Doris Graber contends that the Truman and Eisenhower Doctrines were unnecessary and hard to apply. The former was too broad and the latter too narrow. The broadness of the Truman Doctrine made it impossible to be fully implemented; the Eisenhower Doctrine was 1 imited by the fact that its implementation depended on the consent of the Middle Eastern nation in question. Graber suggests that

it would be best to reaffirm the traditional rule--which is being applied in practice-that intervention will remain a last resort to be used when the United States considers itseif seriously endangered.1

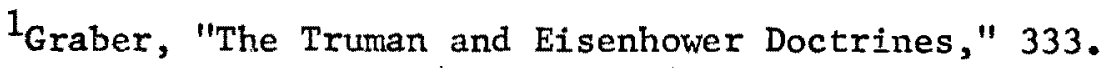


In general, U.S. policy in the Middle East between 1946 and 1958, was negative in approach; it emphasized military considerations; it misinterpreted the nature of the Soviet communist threat; and it heavily committed the United States in support of reactionary and unworthy regimes. When George Kennan first enunciated the policy of containment, he warned that, for it to succeed, the United States must cope with her responsibilities as a world power, which "has a spiritual vitality capable of holding its own among the major ideological currents of the time. To the extent that such an impression can be created and maintained, the aims of Russian Conmunism must appear sterile and quixotic."1 Kennan goes on to say that "the United States need only measure up to its own best traditions and prove itself worthy of preservation as a great power."2

By 1958, it became doubtful whether the United States could measure up to this standard. A pro-American Iraqi politician, Dr. Fadhil al-Jamali, concluded, before 1958, that the United States was losing the struggle "for the minds of men." 3 George Kennan may have been right when he said, "it was not 'containment' that failed; it was the intended follow up that never occurred." 4

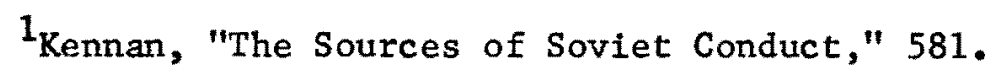
2 Ibid., 582 .

3Quoted in Castleberry, "The Arabs' View of Post-war American Foreign Policy," 25.

4Kennan, "The Sources of Soviet Conduct," 365. 


\section{BIBLIOGRAPHY}

Acheson, Dean Gooderham, Present at the Creation: My Years at the State Department. New York: Norton, 1969.

Adams, Michael. "The Frustrated Civil War." The Reporter, XIX (August 7, 1958), 17-18. 1958.

- Suez and After: Year of Crisis. Boston: Beacon Press,

Agwani, Mohammed Safi. The United States and the Arab World, 19451952. Aligarb: Institute of Islamic Studies, Muslim University, 1955.

a1-Ahram (Cairo), September 17, 24, October 15, 1971.

Alliluyeva, Svetlana. Twenty Letters to a Friend. New York: Harper \& Row, 1967.

Antonius, George. The Arab Awakening. New York: G.P. Putnam's Sons, 1946.

Arab News Bulletin (London), December 12, 1947.

Attlee, Clement Richard. As It Happened. London: W. Heinemann, 1954.

Bailey, Thomas A. A Diplomatic History of the American People. New York: F. S. Crofts \& Co., 1946.

Beal, John Robinson. John Foster Dulles: 1888-1959. New York: Harper \& Row, 1959.

Bemis, Samuel F. A Diplomatic History of the United States. New York: Holt, Rinehart and Winston, Inc., 1967.

Bowles, Chester. "Long-term Issues in the Middle East." Academy of Political Science Proceedings, XXVI (May, 1957), 98-109.

Boze11, L. Brent. "The Mid-eastern Policy." National Review, III (January 19, 1957), 56-57.

Buehrig, Edward. "The Arab World and the United States: A Critical Survey of American Policy in the Middle East." Middle East Forum, XXXIII (Ju1y, 1958), 9-11, 29, 31, 33. 
Byroade, Henry A. "Facing Realities in the Arab-Israeli Dispute." U.S. Department of State. Bulletin, Vo1. XXX, May 10, 1954.

- "The Middle East in New Perspective." U.S. Department of State. Bu1letin, Vo1. XXX, April 26, 1954.

- "U.S. Foreign Policy in the Middle East." U.S. Department of State. Bulletin, Vo1. XXVII, December 15, 1952.

Campbe11, John Coert. "America and the Middle East." India Quarterly, XV (April/June, 1959), 142-50.

- Defense of the Middle East: Problems of American Pollcy. New York: Published for the Council on Foreign Relations by Harper \& Row, 1958.

- The Middle East in the Muted Cold War. Denver: University of Denver, 1964.

Castleberry, H. Paul. "The Arabs' View of Postwar Anerican Foreign Policy." Western Politica1 Quarterly, XXII (March, 1959), 9-36.

Christian Science Monitor, August 7, 1952.

Churchi11, Winston Leonard Spencer. The Second World War. Vo1. V. Boston: Published in association with the Cooperation Publishing Co. by Housghton Miff1in, 1948-53.

Commager, Henry Steele, ed. Documents of American History. New York: Appleton-Century-Crofts, 1949.

Cook, Fred J. "The CIA." The Nation, Special Issue (June 24, 1961).

Copeland, Miles. The Game of Nations: The Amorality of Power Politics. London: Weidenfeld \& Nicolson, 1969.

- The Game of Nations: The Amorality of Power Politics. New York: Simon and Schuster, 1969.

Cottam, Richard. Nationalism in Iran. Pittsburgh: University of Pittsburgh Press, 1964.

Cox, Frederick J. "The American Naval Misson in Egypt." The Journal of Modern History, XXVI (June, 1954), 173-78.

Crabb, Cecil Van Meter, Jr. Bipartisan Foreign Policy: Myth and Reality. Evanston, I1linois: Row, Peterson, 1957. 
Crabites, Pierre. Americans in the Egyptian Army. London: G. Routledge \& Sons, Ltd., 1938.

Crossman, Richard. "The Role Britain Hopes to Play. . ." Commentary, V (June, 1948), 493-97.

Dagan, Avigdor. Moscow and Jerusalem: Twenty Years of Relations Between Israel and the Soviet Union. New York: AbelardSchuman, 1970.

Daniel, Robert L. American Philanthropy in the Near East, 18201960. Athens: Ohio University Press, 1970.

Daniels, Jonathan. The Man of Independence. New York: Lippincott, 1950.

Dayan, Moshe. Diary of the Sinai Campaign. New York: Harper \& Row, 1966.

Deans, Ralph C. "American Policy in the Middle East." Editorial Research Reports, II (August 19, 1970), 609-26.

DeNovo, John A. American Interests and Politics in the Middle East, 1900-1939. Minneapolis: University of Minnesota Press, 1963.

Documents on American Foreign Relations, July 1, 1945-December 31, 1946. Vo1. VIII. Princeton, N.J.: Published for the World Peace Foundation by Princeton University Press, 1948.

, 1947. Vol. IX. Princeton, N.J.: Published for the World Peace Foundation by Princeton University Press, 1949.

Dougherty, James E. "The Aswan Decision in Perspective." Politica1 Science Quarterly, LXXIV (March, 1959), 21-45.

Drummond, Roscoe, and Coblentz, Gaston. Duel at the Brink: John Foster Dulles' Command of American Power. Garden City, N.Y.: Doubleday, 1960.

Dulles, Allen. The Craft of Intelligence. New York: Harper \& Row, 1963.

Dulles, John Foster. "Report on the Near East." U.S. Department of State. Bulletin, Vo1. XXVIII, June 15, 1953.

Eden, Anthony. Ful1 Circle: The Memoirs of Anthony Eden. Boston: Houghton, Mifflin, 1960.

Egyptian Gazette (Cairo), Apri1 20, 1950.

Eisenhower, Dwight David. Mandate for Change, 1953-1956: The White House Years. Garden City, N.Y.: Doubleday, 1963. 
- Waging Peace, 1956-1961: The White House Years. Garden City, N.Y.: Doubleday, 1965.

"The Eisenhower Doctrine: Beginnings of a Middle East Policy." Round Table, XLVII (March, 1957), 141-47.

EI11s, Harry B. Challenge in the Middle East: Communist Influence and American Policy. New York: Ronald Press Co., 1960.

Fatemi, Nasrotallah S. Oil Diplomacy: Powder Keg in Iran. New York: Whittier Books, 1954.

"The Present Crisis in the Middle East." The Big Powers and the Present Crisis in the Middle East: A Colloquium. Edited by Samuel Merlin. Rutherford: Fairleigh Dickinson University Press, 1968.

Feis, Herbert. The Birth of Israel: The Tousled Diplomatic Bed. New York: Norton, 1969.

Field, James A., Jr. America and the Mediterranean Wor1d, 1776-1882. Princeton, N.J.: Princeton University Press, 1960.

Finer, Herman. Dulles over Suez: The Theory and Practice of his Diplomacy. Chicago: Quadrangle Books, 1964.

Finnie, David H. Pioneers East: The Early American Experience in the Middle East. Cambridge, Mass.: Harvard University Press, 1967.

Fitzsimons, M.A. "Suez Crisis and the Containment Policy." Review of Politics, XIX (October, 1957), 419-45.

Fontaine, Andre. History of the Cold War from the October Revolution to the Korean War, 1917-1950. New York: Random House, 1968.

- History of the Cold War from the Korean War to the Present. New York: Random House, 1969.

Forrestal, James. The Forrestal Diaries. Edited by Walter Millis with the collaboration of E.S. Duffield. New York: Viking Press, 1951.

"From the Shores of Tripoli to the Oilfields of Arabia." Egyptian Economic and Political Review, International Edition (June, 1955), 14-22.

Frye, Richard Nelson, ed. The Near East and the Great Powers. Cambridge, Mass.: Harvard University Press, 1951.

Garcia-Granados, Jorge. The Birth of Israel: The Drama as I Saw It. New York: A.A. Knopf, 1948. 
Gordon, Leland J. American Relations with Turkey, 1830-1930: An Economic Interpretation. Philadelphia: University of Pennsylvania Press, 1932.

Graber, Doris A. "The Truman and Eisenhower Doctrines in the Light of the Doctrine of Non-intervention. Political Science Quarterly, LXXIII (September, 1958), 321-34.

Grady, Henry F. "Tension in the Middle East with Special Reference to Iran." Academy of Political Science Proceedings, XXIV (January, 1952), 114-20.

Great Britain. Parliament. Papers by Command. Cmnd. 6808. The Anglo-American Committee of Inquiry, Final Report, 1946. London: His Majesty's Stationery Office, 1946.

Hakim, George. "Point Four and the Middle East: A Middle East View." The Middle East Journal, IV (April, 1950), 183-95.

Hanna, Paul. "America in the Middle East." Middle Eastern Affairs, X (May, 1959), 178-90.

Harkness, Richard, and Harkness, Gladys. "The Mysterious Doings of the CIA." Saturday Evening Post, CCXXVII (November 6, 1954), 34ff.

Hayka1, Mohammad Hasanayn. Nahnu . - wa-Amrika. Cairo: Dar a1-'Asr al-Hadith, 1967.

Hopkins, Harry. Egypt, the Crucible: The Unfinished Revolution in the Arab World. Boston: Houghton, Mifflin, 1969.

Horowitz, David. The Free World Colossus: A Critique of American Foreign Policy in the Cold War. New York: Hill and Wang, 1965.

Hoskins, Halford L. "Some Aspects of the Security Problem in the Middle East." American Political Science Review, XLVII (March, 1953), 188-98.

Hourani, Albert Habib. Arabic Thought in the Liberal Age, 1798-1939. London: Oxford University Press, 1962.

Howard, Harry Nicholas. The King-Crane Commission: An American Inquiry in the Middle East. Beirut: Khayat, 1963.

Humphrey, Hubert H. "A Chronology of Failure." The Reporter, XIX (August 7, 1958), 11-14. 
Hurewitz, Jacob Coleman. Diplomacy in the Near and Middle East: A Documentary Record. Vo1. II. New York: Van Nostrand, 1956.

, ed. "Soviet-American Riva1ry in the Middle East." Academy of Political Science Proceedings, XXIX (March, 1969), 1-2i7.

- The Struggle for Palestine. New York: Norton, 1950.

"The Ike Doctrine Powder Keg." Jana, IV (June, 1957), 4-8.

"Isolation or Entanglement." Egyptian Economic and Political Review, Internationa1 Edition (December, 1956/January, 1957), 13-16, 19-21.

Issawi, Charles. "Middle East Dilemmas: An Outline of Problems." Journal of International Affairs, XIII, No. 2 (1959), 102-12.

Jum'ah, Rabih Lutfj. Sahq al-'Udwan al-Thulathi. Cairo: a1-Dar a1-Qawniyah 1i1-Ti.ba' ah wa-a1-Nashr, 1962.

Kennan, George F. American Diplomacy, 1900-1950. Chicago: Chicago University Press, 1951. 1967.

Kerr, Malcolm. "'Coming to Terms with Nasser': Attempts and Failures." International Affairs (London), XIIII (January, 1967), 65-84.

Khadduri, Magid. "American Foreign Policy in the Middle East." S.A.I.S. Review, V (Spring, 1966), 18-22.

Khouri, Fred John. The Arab-Israeli Dilemma. Syracuse, N.Y.: Syracuse University Press, 1968.

Khrushchev, Nikita S. Khrushchev Remembers. Introduction, commentary and notes by Edward Crankshaw. Translated and edited by Strobe Talbott. Boston: Little, Brown and Company, 1970.

Kirk, George. "The Syrian Crisis of 1957--Fact and Fiction." Internationa1 Affairs (London), XXXVI (January, 1960), 58-61.

LaFeber, Walter. America, Russia, and the Cold War, 1945-1966. New York: Wiley, 1967.

Laqueur, Walter $\mathrm{z}$. Communism and Nationalism in the Middle East. New York: Praeger, 1957. 
1959.

- The Struggle for the Middle East: The Soviet Union and

the Middle East, 1958-68. London: Routledge \& K. Paul, 1969.

Lenczowski, George. The Middle East In World Affairs. Ithaca, N.Y.:

Corne11 University Press, 1962.

- Oi1 and State in the Middle East. Ithaca, N.Y.: Corne11 University Press, 1960.

- Russia and the West in Iran, 1918-1948. Ithaca, N.Y.:

Corne11 University Press, 1949.

Lengye1, Emil. The Changing Middle East. New York: John Day Co., 1960.

Lens, Sidney. "The Dulles Dilemma in the Middle East." The Progressive, XXII (September, 1958), 7-10.

Lindsay, Roa Humphreys. Nineteenth Century American Schools in the Levant: A Study of Purposes. Ann Arbor: University of Michigan Press, 1965.

Lippmann, Walter. Public Opinion and Foreign Policy in the United States. London: Allen \& Unwin, 1952.

- U.S. Foreign Policy: Shield of the Republic. Boston:

Little, Brown and Company, 1943.

McClintock, Robert. "The American Landing in Lebanon: Summer of 1958." U.S. Naval Institute Proceedings, LXXXVIII (October, 1962), 64-79.

McNei1, William Hardy. America, Britain and Russia: Their Cooperation and Conflict, 1941-1946. Survey of International Affairs, 1939-1946. Vo1. III. Oxford: Oxford University Press, 1953.

Magnus, Ralph H., comp. Documents on the Middle East. Washington, D.C.: American Enterprise Institute on Public Policy Research, 1969.

- "Political-Strategic Interests." United States Interests in the Middle East. Edited by George Lenczowski. Washington, D.C.: American Enterprise Institute on Public Policy Research, 1968. 
Manuel, Frank E. The Realities of American-Palestine Relations. Washington, D.C.: Pub1ic Affairs Press, 1949.

Marlowe, John. Iran: A Short Political Guide. New York: Praeger, 1963.

Middle East Journal, VIII (Winter, 1954), 446-47.

Middle East Opinion, I (June 10, 1946).

Minor, Harold. "Commentary Lon Elie Salem's Problems of Arab Political Behavior/." Tensions in the Middle East. Edited by Philip Warren Thayer. Baltimore: Johns Hopkins Press, 1958.

Monroe, Elizabeth. "Mr. Bevin's 'Arab Policy.'" St. Anthony's Papers, No. 11, Middle Eastern Affairs, No. 2. Edited by Albert Hourani. London: Chatto \& Windus, 1961.

Morath, Inge. From Persia to Iran. London: Thames and Hudson, 1960 .

Murphy, Robert.Danie1. Diplomat Among Warriors. Garden City, N.Y.: Doubleday, 1964.

New York Times, October 12, 1944, October 5, 1946, May 16, 23, June $6,11,14$, July 1, October 11, 29, 1948, July 2, 3, 1950, February 11, October 24, November 9, 1951, February 10, June 20, July 20, 22, 24, 1956, August 14, 18, 22,

September 14, 21, October 15, November 1, 13, 1957, July 18, 1958.

Nirumand, Bahman. Iran: The New Imperialism in Action. New York: Monthly Review Press, 1969.

Nolte, Richard H. "American Policy in the Middle East." Journa1 of International Affairs, XIII, No. 2 (1959), 113-25. , and Polk, William Roe. "Toward a Policy for the Middle East." Foreign Affairs, XXXVI (July, 1958), 645-58.

Nutting, Anthony. No End of a Lesson: The Story of Suez. New York: C. N. Potter, 1967.

Pahlavi, Modanmed Reza Shah. Mission for My Country. New York: McGraw-Hi11, 1961.

Pear1, Marian A. "America in the Middle East." Contemporary Issues, X. (May/June, 1960), 81-91. 
Peretz, Don. The Middle East Today. New York: Rinehart and Winston, 1963.

Perlman, M. "Withdrawal in East--Retreat in West." Middle Eastern Affairs, VIII (May, 1957), 174-80.

Philby, H.A.R. "Nasser and the West." Middle East Forum, XXXIV (Apri1, 1959).

Polk, William Roe. The United States and the Arab World. Cambridge, Mass.: Harvard University Press, 1969.

Ramazani, R. K. "Changing United States Policy in the Middle East." The Virginia Quarterly Review, XL (Summer, 1964), 369-82.

Qubain, Fahim Issa. Crisis in Lebanon, Washington, D.C.: Middle East Institute, 1961.

Reisman, Michael. The Art of the Possible: Diplomatic Alternatives In the Middle East. Princeton, N.J.: Princeton University Press, 1970.

Reitze1, William; Kaplan, Morton A.; and Coblenz, Constance G. United States Foreign Policy, 1945-1955. Washington, D.C.: Brookings Institution, 1956.

Richardson, James Daniel, comp. A Compilation of the Messages and Papers of the Presidents, 1789-1897. Vol. IV. Washington, D.C.: Government Printing Office, 1896-99.

Richter, Ju1ius. A History of Protestant Missions in the Near East. New York: Fleming H. Reve11 Company, 1910.

Rooseve1t, Kermit. "The Partition of Palestine: A Lesson in Pressure Politics." Middle East Journal, II (January, 1948), $1-16$.

Sacher, Harry. Israel: The Establishment of a State. London: Weidenfeld \& Nicolson, 1952.

Sadiq, Samir. Qissat al-'Udwan al-Thulathi 'ala Misr (Cairo: a1-Dar a1-Qawniyah 1i1-Tiba'ah wa-a1-Nashr, 1961.

St. John, Rubert. The Boss: The Story of Gamal Abde1 Nasser. New York: McGraw-Hi11, 1960.

Salibi, Kamal Suleiman. The Modern History of Lebanon. New York: Praeger, 1965. 
Sanger, Richard H. "American Policy in the Middle East During 1953." U.S. Department of State. Builetin, Vo1. XXX, February 8, 1954.

Sayegh, Fayez A. "The Arab Reaction to American Policy." Socia1 Science, XXVII (October, 1952), 189-94.

Seale, Patrick. The Struggle for Syria: A Study in Post-war Arab Politics. Issued under the auspices of the Royal Institute of International Affairs. New York: Oxford University Press, 1965.

Sheehan, Michae1 Kah1. Iran: The Impact of United States Interests and Policies, 1941-1954. Brooklyn, N.Y.: Theo. Gaus' Sons, 1968.

Shwadran, Benjamin. The Middle East: $0 i 1$ and the Great Powers. New York: Praeger, 1955.

Sokolow, Nahum. History of Zionism, 1600-1918. Introduction by A. J. Balfour. Vo1. I. New York: KTAV Publishing House, 1969.

Spain, J.W. "Middle East Defense: A New Approach." Middle East Journal, VIJI (Summer, 1954), 250-66.

Spanier, John W. American Foreign Policy Since World War II. New York: Praeger, 1968.

Sprout, Harold, and Sprcut, Margaret. The Rise of American Naval Power, 1776-1918. Princeton, N.J.: Princeton University Press, 1967.

Stein, Leonard Jacques. The Balfour Declaration. London: Vallentine, Mitche11, 1961.

Stettinius, Edward Reilly, Jr. Roosevelt and the Russians: The Yalta Conference. Edited by Walter Johnson. Garden City, N.Y.: Doubleday, 1949.

Stevens, Georgiana G., ed. The U.S. and the Middle East. Englewood Cliffs, N.J.: Prentice-Ha11, 1964.

Strausz-Hupe, Robert. "The United States and the Middle East." Tensions in the Middle East. Edited by Philip Warren Thayer. Baltimore: Johns Hopkins Press, 1958.

; Cottrel1, Alvin J.; and Dougherty, James E., eds. AmericanAsian Tensions. New York: Praeger, 1956. 
Thayer, Charles Wheeler. Diplomat. New York: Harper \& Row, 1959.

Thomas, Hugh. The Suez Affair. London: Weidenfeld \& Nicolson, 1967.

Thornburg, Max Weston. People and Policy in the Middle East: A Study of Social and Political Change as a Basis for United States Policy. New York: Norton, 1964.

Tibawi, Abdul Latif. American Interests in Syria, 1800-1901. Oxford: Clarendon Press, 1966.

Time, November 12, 1956.

Titov, G. "The Eisenhower Doctrine and the Peoples of the East." International Affairs (Moscow), May, 1958, pp. 35-41.

Torrey, Gordon H. Syrian Politics and the Military, 1945-1958. Columbus: Ohio State University, 1964.

Truman, Harry S. Memoirs. Vols. I, II. Garden City, N.Y.: Doubleday, 1955-56.

Tully, Andrew. CIA: The Inside Story. New York: Morrow, 1962.

United Nations. General Assembly. Official Records, 128 Plenary Meeting, 1947. Vo1. II, p. 1425, Appendix A (III).

- Special Committee on Palestine. Report on Palestine: Report to the Second Session of the General Assembly. New York: Somerset Books, 1947.

United Nations. Yearbook, 1946-47. Lake Success, N.Y.: U.N. Department of Public Information, 1947.

, 1947-48. Lake Success, N.Y.: U.N. Department of Public Information, 1948 .

U.S. Congress. 79th Cong., 1st sess., June 11-October 11, 1945, Congressional Record, Vol. IXC, pt. 12.

, October 15-December 21, 1945, Congressional Record, Vol. IXC, pt. 13 .

U.S. Department of State. American Foreign Policy, Current Documents, 1956. Washington, D.C.: Government Printing Office, 1959.

, 1957. Washington, D.C.: Government Printing Office, 1961. 
, 1958. Washington, D.C.: Government Printing Office, 1962.

U.S. Department of State. Bulletin, Vo1. XIV, March 17, May 12, 1946, Vol. XVI, March 23, 1947, Vo1. XX, March 27, Apri1 3, 1949, Vo1, XXV, October 22, 29, November 19, 1951, Vol. XXXIV, February 20, 1956, Vo1. XXXV, August 6, 13, 27, October 15, November 12, 1956, Vo1. XXXVI, January 21, February 4, March 25, Apri1 1, June 17, July 1, 1957, Vo1. XXXIX, July 14, 1958.

U.S. Department of State. Foreign Relations of the United States, Diplomatic Papers, Vol. V (1944). Washington, D.C.: Government Printing Office, 1967.

, Vol. VIII (1945). Washington, D.C.: Government Printing Office, 1967-69.

, The Conference of Berlin, Vols. I, II (1945). Washington, D.C.: Government Printing Office, 1960.

, Vo1. VI (1946). Washington, D.C.: Government Printing Office, 1969.

U.S. President. Public Papers of the Presidents of the United States. Washington, D.C.: Office of the Federal Register, National Archives and Records Service, 1945-. Harry S. Truman, 1952.

U.S. News, August 30, 1946.

Ushakov, Georgi. "Dulles' 'Aswan Gambit': The Story of a Cold-war Fiasco." New Times (Moscow), May 19, 1946, pp. 26-29.

Wa11 Street Journal, July 22, 1958.

Weizmann, Chaim. Trial and Error. New York: Harper \& Row, 1949.

Welles, Sumner. We Need Not Fail. Boston: Houghton, Mifflin Co., 1948.

Westerfie1d, Bradford. Foreign Policy and Party Politics: Pear1 Harbor to Korea. New Haven: Yale University Press, 1955.

"What Should the U.S. Do In the Middle East? Interview with Egypt's Prime Minister Lieut. Col. Gamal Abdel Nasser." U.S. News \& World Report, September 3, 1954, pp. 26-32.

Wheeler, Geoffrey. "Russia and the Middle East." Political Quarterly, XXVIII (April, 1957), 127-36. 
Williams, Francis. Ernest Bevin: Portrait of a Great Englishman. London: Hutchinson, 1952.

- Twilight of Empire: Memoirs of Prime Minister Clement Attlee, as set down by Francis Williams. New York: Barnes, 1962.

Williams, William Appleman. America and the Middle East. New York: Rinehart, 1958.

Wright, Walter Livingston, Jr, "Contradictory Foreign Policies in the Near East." Virginia Quarterly Review, XXIII (March, 1947), 179-92.

Wynn, Wilton. Nasser of Egypt: The Search for Dignity. Cambridge, Mass .: Arlington Books, 1959.

Young, T. Cuyler. "Iran in Continuing Crisis." Foreign Affairs, XL (January, 1962), 275-92.

$\mathrm{X} \perp \overline{\mathrm{K}}$ ennan, George $\mathrm{F}_{-} \bar{l}$. "The Sources of Soviet Conduct." Foreign Affairs, XXV (July, 1947), 566-82.

Zhukov, E.M. "The Eisenhower Doctrine and U.S. Foreign Policy." International Affairs (Moscow), February, 1957, pp. 60-84.

Zinner, Paul E., ed. Documents on American Foreign Policy, 1955. New York: Columbia University Press, 1956. 